\title{
Beroepenmobiliteit: bruikbaarheid longitudinale gegevens enquête beroepsbevolking
}

Citation for published version (APA):

Bierings, H., Cörvers, F., Montizaan, R. M., \& de Vries, M. R. (2009). Beroepenmobiliteit: bruikbaarheid longitudinale gegevens enquête beroepsbevolking. ROA. ROA Technical Reports No. 2 https://doi.org/10.26481/umarot.2009002

Document status and date:

Published: 01/01/2009

DOI:

10.26481/umarot.2009002

Document Version:

Publisher's PDF, also known as Version of record

\section{Please check the document version of this publication:}

- A submitted manuscript is the version of the article upon submission and before peer-review. There can be important differences between the submitted version and the official published version of record.

People interested in the research are advised to contact the author for the final version of the publication, or visit the DOI to the publisher's website.

- The final author version and the galley proof are versions of the publication after peer review.

- The final published version features the final layout of the paper including the volume, issue and page numbers.

Link to publication

\footnotetext{
General rights rights.

- You may freely distribute the URL identifying the publication in the public portal. please follow below link for the End User Agreement:

www.umlib.nl/taverne-license

Take down policy

If you believe that this document breaches copyright please contact us at:

repository@maastrichtuniversity.nl

providing details and we will investigate your claim.
}

Copyright and moral rights for the publications made accessible in the public portal are retained by the authors and/or other copyright owners and it is a condition of accessing publications that users recognise and abide by the legal requirements associated with these

- Users may download and print one copy of any publication from the public portal for the purpose of private study or research.

- You may not further distribute the material or use it for any profit-making activity or commercial gain

If the publication is distributed under the terms of Article $25 \mathrm{fa}$ of the Dutch Copyright Act, indicated by the "Taverne" license above, 


\title{
Beroepenmobiliteit: Bruikbaarheid longitudinale gegevens Enquête Beroepsbevolking
}

\author{
Harry Bierings (CBS) \\ Frank Cörvers (ROA) \\ Raymond Montizaan (ROA) \\ Robert de Vries (CBS)
}

ROA-TR-2009/2

Mei 2009

Researchcentrum voor

Onderwijs en Arbeidsmarkt

Postbus 616

6200 MD Maastricht

E-mail: secretary@roa.unimaas.nl

Internet: $\quad$ www.roa.unimaas.nl

Universiteit Maastricht

Faculteit der Economische Wetenschappen en Bedrijfskunde 
ISBN-978-90-5321-475-6

Sec09.037.pdf 


\section{Inhoud}

Bladzijde

Voorwoord

$1 \quad$ Inleiding

2 Beroep

3 Beroepenmobiliteit

$4 \quad$ Plausibiliteit EBB paneldata $\quad 7$

$\begin{array}{ll}4.1 \text { Uitval } & 7\end{array}$

4.2 Proxy beantwoording 9

4.3 Verandering van werkkring of beroep 10

5 Uitkomsten beroepenmobiliteit $\quad 14$

5.1 Beroepenmobiliteit in de EBB 15

5.2 Beroepenmobiliteit naar achtergrondkenmerken 24

5.3 Beroepenmobiliteit volgens de internationale definitie van $\begin{array}{ll}\text { werkloosheid } & 30\end{array}$

5.4 Beroepenmobiliteit op 3 digit niveau 35

5.5 Samenvatting 35

6 Conclusies 36 
$7 \quad$ Literatuur

Bijlage 1: EBB vragenlijstschema beroep

Bijlage 2: Paneluitval uitkomsten

Bijlage 3: Beroepenmobiliteit naar uren en digit niveau 50

Bijlage 4: Beroepenmobiliteit op 3 digit niveau, 2002-2005

55

Bijlage 5: Beroepenmobiliteit (1 digit)

Bijlage 6: Weging beroepenmobiliteit 


\section{Voorwoord}

Deze studie is een verslag van een gezamenlijk onderzoek van het Centraal Bureau voor de Statistiek (CBS) en het Researchcentrum voor Onderwijs en Arbeidsmarkt (ROA).

De studie is een onderdeel van zowel het CBS-speerpunt Sociale dynamiek en uitbreiding Arbeidsrekeningen, in het bijzonder het project Onderwijs en beroepsloopbaan, als het Project Onderwijs-Arbeidsmarkt van het ROA. Het Project Onderwijs-Arbeidsmarkt wordt gefinancierd door het Ministerie van Onderwijs, Cultuur en Wetenschap (OCW), het Uitvoeringsinstituut Werknemersverzekeringen (UWV), het UWV Werkbedrijf, het Ministerie van Landbouw, Natuur en Voedselkwaliteit (LNV), de samenwerkende kenniscentra voor beroepsonderwijs en bedrijfsleven COLO, Randstad Nederland en de Raad voor Werk en Inkomen (RWI).

De hoofdstukken 2, 3 en 4 zijn door het CBS samengesteld, hoofdstuk 5 door het ROA. De overige hoofdstukken zijn een gezamenlijk product. Bijlage 4 is door het ROA samengesteld, de overige bijlagen door het CBS.

De auteurs bedanken Henk-Jan Dirven, Wendy Smits, Johan van der Valk en de leden van de begeleidingscommissie van het Project Onderwijs-Arbeidsmarkt voor het commentaar op een eerdere versie.

De in dit rapport weergegeven opvattingen zijn die van de auteurs en komen niet noodzakelijk overeen met het beleid van het Centraal Bureau voor de Statistiek. 



\section{Inleiding}

Volgens veel toekomststudies wordt de arbeidsmarkt gekenmerkt door een toenemende flexibiliteit en mobiliteit, veroorzaakt door trends zoals informatisering, internationalisering en individualisering. ${ }^{1}$ Ook in de herziene Lissabonstrategie en de Sociale Beleidsagenda 2006-2010 wordt het belang van een verdere verbetering van de arbeidsmarktflexibiliteit onderstreept. ${ }^{2}$ Zowel Europees als ook nationaal beleid zet in op flexibilisering van de arbeidsmarkt in het belang van de concurrentiepositie. Een grotere mobiliteit op de arbeidsmarkt wordt gezien als één van de manieren om dit doel te bereiken. De toename van de mobiliteit van werknemers kan zijn oorsprong hebben in meer numerieke flexibiliteit, i.e. baan- en beroepenmobiliteit, als ook meer functionele flexibiliteit, i.e. kennisontwikkeling, scholing en training. Voor de statistiek ontstaat aldus een beleidsbehoefte aan cijfers over baan- en beroepenmobiliteit, en de rol daarbij van investeringen in scholing en training. In deze haalbaarheidsstudie wordt een eerste stap gezet naar een statistiek over beroepenmobiliteit.

Uit de Enquête Beroepsbevolking (EBB) zijn panelgegevens over beroepenmobiliteit beschikbaar. De vraag die in deze studie centraal staat is of op basis van deze gegevens een adequaat beeld van de beroepenmobiliteit in Nederland kan worden gegeven. Deze vraag wordt beantwoord door allereerst de data te analyseren op betrouwbaarheid en kwaliteit. Daarbij wordt aandacht besteed aan de omvang en de selectiviteit van de paneluitval en het effect van proxy beantwoording op de kwaliteit van de data. Ten tweede zijn de uitkomsten over beroepenmobiliteit volgens de EBB vergeleken met die op basis van het Sociaaleconomisch Panelonderzoek (SEP) voor de periode 1995-2001. Daarbij is zowel naar de omvang en de richting van de mobiliteitstromen gekeken. Op basis van deze vergelijking stellen we de plausibiliteit van de uitkomsten over beroepenmobiliteit vast.

De opzet van dit rapport is als volgt. De afbakening van beroep en mobiliteit komen respectievelijk aan de orde in hoofdstuk 2 en hoofdstuk 3. Hoofdstuk 4 gaat in op de kwaliteit van de paneluitkomsten. Er wordt in het bijzonder ingegaan op de omvang en selectiviteit van de uitval. Hoofdstuk 5 bevat de uitkomsten van de analyse over beroepenmobiliteit. In hoofdstuk 6 worden de conclusies van het onderzoek weergegeven.

\section{Beroep}

Bij de afbakening van het begrip beroep wordt aangesloten bij (inter)nationale conventies, in casu de Standaard Beroepenclassificatie (SBC) 1992, die ook in de EBB is toegepast. De SBC 1992 is een conceptuele uitwerking van de vraag welke beroepenafbakening zinvol is voor arbeidsmarktonderzoek in het algemeen, maar voor de beschrijving van substitutieprocessen in het bijzonder. Zij is tot stand gekomen uit een brede consensus over wat qua concept onder "beroep" verstaan zou moeten worden. De belangrijkste overwegingen worden hieronder genoemd. Voor een uitgebreide onderbouwing wordt verwezen naar ILO (1987) en CBS (2001).

Definitie In de SBC 1992 is een "beroep" gedefinieerd als een verzameling van gelijksoortige takenpakketten. Takenpakketten refereren aan gelijksoortige bekwaamheden naar niveau, richting en soort van werkzaamheden (werksoort). Niveau en richting van de

\footnotetext{
${ }^{1}$ Zie voor een overzicht blz. 269-312 in SCP (2004).

${ }^{2}$ Europese Raad van Ministers (2005).
} 
bekwaamheden zijn primair gedefinieerd vanuit de benodigde kennis en vaardigheden zoals die in het onderwijs worden aangeleerd. Het gaat dan om de opleiding die het beste voorbereidt op de werkzaamheden in het takenpakket. Deze zogenaamde meest geëigende opleiding per takenpakket is door beroepenkundigen vastgesteld aan de hand van de Standaard Onderwijsindeling, SOI (CBS, 1989). Op deze wijze is getracht de SBC 1992 zoveel mogelijk ongevoelig te houden voor conjunctureel bepaalde verschillen. In aanvulling op de meest geëigende opleiding speelt naast de vaststelling van het niveau in elementair, lager, middelbaar en hoger en wetenschappelijk ook de duur van de vakspecialistische ervaring een rol. Bij de richting gaat het dan ook om de aard van de vakspecialistische ervaring (bijvoorbeeld: bouwkundig, weg- en waterbouwkundig of landmeetkundig). Werksoort heeft betrekking op bekwaamheden die niet in niveau of richting zijn vervat, zoals bijvoorbeeld calculeren, inspecteren, bezorgen of bankwerken.

Door combinatie van de 3 criteria (5 niveaus, 13 hoofdrichtingen, 87 richtingen en 128 werksoorten) kunnen 1211 beroepen worden onderscheiden.

EBB De wijze waarop in de EBB het beroep wordt vastgesteld komt overeen met die in andere surveys zoals de Current Population Survey (CPS) in de V.S. Hieronder wordt in hoofdlijnen beschreven hoe het beroep wordt geregistreerd. Bijlage 1 bevat de details.

In de EBB-vragenlijst wordt eerst vastgesteld of iemand betaald werk heeft in één of meerdere werkkringen en met welke wekelijkse arbeidsduur. De werkkring met de hoogste wekelijkse arbeidsduur wordt als hoofdwerkkring bestempeld. De benaming van de werkkring wordt door de respondent zelf gekozen en alfanumeriek opgeslagen. Meestal zal dit een aanduiding van de werkgever zijn (bijv.: Universiteit Maastricht). Zij die een werkkring hebben krijgen de vragen van de beroepsmodule voorgelegd. In de laptop van de interviewer is hiervoor een zoekmachine ingebouwd die het beroep van (uitsluitend) de hoofdwerkkring van de respondent automatisch typeert. Hiervoor worden de antwoorden van de respondent gebruikt op vragen over niveau, richting en werksoort, ofwel de drie criteria zoals die in de SBC voor de afbakening van beroep gelden. ${ }^{3} \mathrm{De}$ automatische typering via de zoekmachine is sinds 2004 in de EBB van toepassing.

\section{Beroepenmobiliteit}

Een statistiek over beroepenmobiliteit geeft aan hoe vaak het voorkomt dat personen in een nieuw beroep zijn gaan werken of uit een beroep stoppen met werken. In de meest ruime invulling worden dan alle transities geteld die iemand gedurende zijn/haar beroepsloopbaan heeft gemaakt. De voor dit doel beschikbare data (EBB) laten zo'n ruime invulling niet toe. Zo zijn uit de EBB-gegevens beschikbaar van een panel van steekproefpersonen voor maximaal 1 jaar op ten hoogste 5 peilmomenten. ${ }^{4}$ Transities in en uit een beroep worden bovendien alleen voor de hoofdwerkkring waargenomen.

\section{Ruime definitie}

Blijft niettemin de vraag of voor een statistiek over beroepenmobiliteit alle in de EBB waargenomen transities mee moeten tellen. Zijn er redenen om bijvoorbeeld transities in en uit kleine baantjes, transities van een klein baantje naar een voltijdbaan buiten

\footnotetext{
${ }^{3}$ Deze vragen zijn niet apart in het vragenlijstschema van bijlage 1 opgenomen.

${ }^{4}$ Daarbij is de afstand tussen de peilmomenten ongeveer even groot, namelijk 3 maanden.
} 
beschouwing te laten? Maar ook: moeten transities waartussen relatief korte tijd zit en waarbij sprake is van terugkeer naar de oorspronkelijke situatie ("draaideurgevallen") wel als werkelijke transities behandeld worden? In het algemeen is geen eenduidig antwoord op deze vragen te geven, maar zullen de keuzes afhankelijk zijn van de specifieke onderzoeksvraag. Dit pleit ervoor de afbakening van beroepenmobiliteit zo ruim mogelijk te houden.

In dit onderzoek dat primair gaat over de vraag of de paneluitkomsten uit de EBB bruikbare informatie over beroepenmobiliteit opleveren, zijn zo min mogelijk beperkingen opgelegd. Het meten van de beroepenmobiliteit op basis van de EBB vereist een preciezere formulering van beroepenmobiliteit. Beroepenmobiliteit gaat over de instroom in een beroep en de uitstroom uit een beroep. Voor een precisering van het begrip beroepenmobiliteit is het nuttig onderscheid te maken tussen beroepvinders, beroepwisselaars en beroepverlaters.

Stel voor een gegeven peilperiode de beroepenmobiliteit $M$ als de som van instroom $I$ en uitstroom $U$ :

Beroepenmobiliteit

$$
M=I+U \text {, waarbij }
$$

$I$, de beroepvinders, te onderscheiden zijn in een instroom vanuit een oud beroep $j$ naar beroep $i$, de beroepwisselaars en de instroom vanuit geen-beroep $k$, ofwel de beroepbeginners (van school, werkloos, pensioen, arbeidsongeschikt,...). ${ }^{5} U$, de beroepverlaters kunnen vanuit een oud beroep $j$ uitstromen naar beroep $i$ of stromen uit naar werkloosheid of richting non-participatie $k$. Samengevat geldt dat:

$$
\begin{array}{ll}
I=I_{j \rightarrow i}+I_{k \rightarrow i}, & \forall i \neq j \neq k \\
U=U_{j \rightarrow i}+U_{j \rightarrow k}, & \forall i \neq j \neq k
\end{array}
$$

De instroom naar beroep $i$ van beroep $j$ kan worden beschouwd als de uitstroom van beroep $j$.

Voor de volledigheid: instroom en uitstroom zijn optellingen. Beperkt tot de uitstroom:

Beroep-

wisselaars

$$
U_{j \rightarrow i}=\sum_{j} \sum_{i} U_{i, j}
$$$$
\forall i \neq j
$$

Beroep-

uitstromers

$$
U_{i \rightarrow k}=\sum_{i} \sum_{k} U_{i, k}
$$$$
\forall j \neq k
$$

\footnotetext{
${ }^{5}$ Beroepvinders en beroepwisselaars zijn termen die geformuleerd zijn naar analogie van baanvinders en baanwisselaars, waarover het CBS al geruime tijd publiceert.
} 
waarbij zij opgemerkt dat $k, i$ en $j$ in verschillende combinaties kunnen voorkomen bij een persoon. In deze studie beperkt de presentatie van de uitkomsten over beroepenmobiliteit zich tot de uitstroom (hoofdstuk 5).

In schema 1 is de instroom (I) in een beroep $\mathrm{x}$ en de uitstroom (U) uit beroep $\mathrm{x}$ grafisch weergegeven. Gegeven de peilperiode tusen peilmomenten 1 en 2 zijn de in- en uitstroom mogelijkheden weergegeven. $I_{1}$ is de instroom van personen die net voor het moment van instroom geen beroep of een ander beroep hadden en in de peilperiode niet meer uitstromen. De instroom $\mathrm{I}_{2}$ stroomt binnen de peilperiode weer uit, enz.

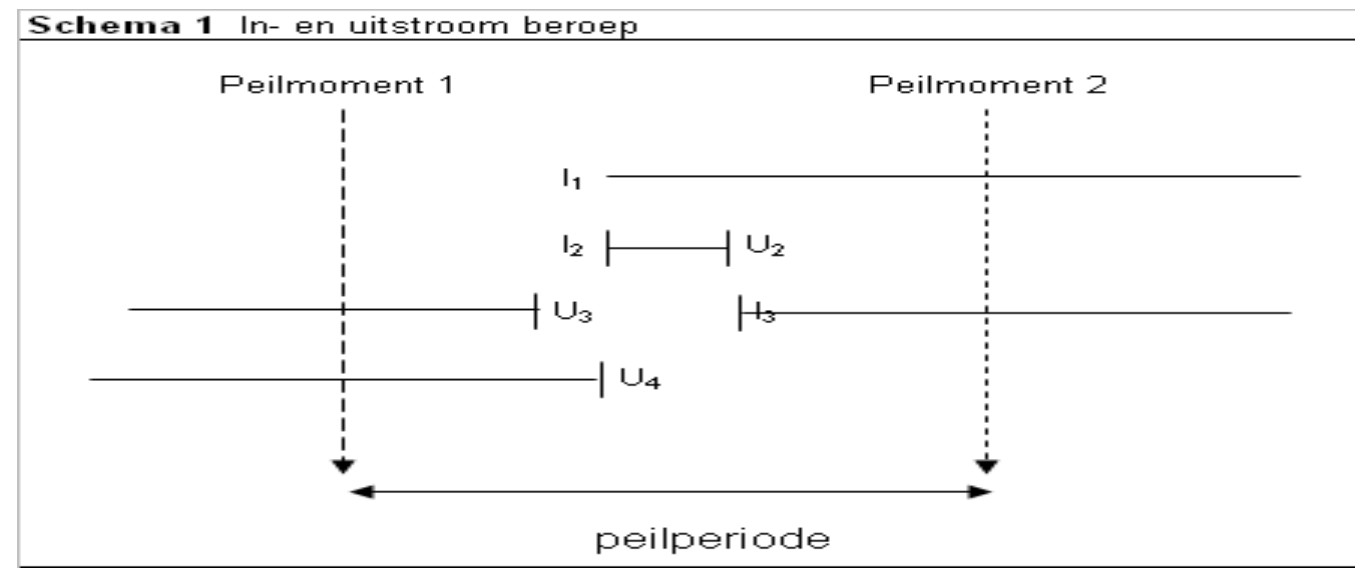

\section{Enquête Beroepsbevolking}

Niet alle transities zoals die in bovenstaande formules zijn vervat, worden in de EBB waargenomen. Zo worden in de EBB uitsluitend transities in en uit een beroep voor de hoofdwerkkring waargenomen. Dit betekent dat als iemand twee baantjes heeft en dan stopt met het kleinste baantje dit niet zichtbaar is uit de EBB. Dit is ook het geval als men naast de hoofdwerking een baantje erbij neemt, of op hetzelfde moment twee banen begint. Op basis van de EBB worden ook nog andere transities niet waargenomen. Voor het EBB-panel is op 5 peilmomenten gedurende een jaar (d.w.z. 5 achtereenvolgende kwartalen) het beroep van de hoofdwerkkring bekend. Maximaal zijn 4 transities van een persoon waar te nemen in een jaar. In dat jaar kan een persoon ten hoogste 2 keer beroepbeginner zijn en dus ook 2 keer een beroepverlater, maar 4 keer een beroepwisselaar.

Er zijn nog andere mogelijkheden, maar we berekenen de beroepenmobiliteit in een jaar Berekening nu door dezelfde groepen paarsgewijs tussen twee kwartalen te vergelijken. Elke veranberoepen- dering (beroepvinder of -verlater) telt dan 1 keer, hetgeen er op neerkomt dat alle waargenomen transities worden meegeteld. Alle veranderingen opgeteld, geeft dan de

Mobiliteit totale beroepenmobiliteit in een jaar. Omdat beroep op het $5^{\text {de }}$ digit van de SBC is gedefinieerd, worden beroepenwisselingen ook op dit niveau vastgesteld. ${ }^{6}$

Uitval Niet voor alle respondenten op een bepaald peilmoment zijn vervolgmetingen beschikbaar. Dat heeft ten eerste te maken met het rotatieschema zoals dat in de EBB voor het panel wordt toegepast. In schema 2 is het EBB-rotatieschema weergegeven.

\footnotetext{
${ }^{6}$ Op welk aggregatieniveau (digit 1, 2 enz.) wordt gepubliceerd, is een andere kwestie en hangt af van de celvulling (betrouwbaarheid).
} 
Ieder kwartaal is opgedeeld in vijf ongeveer even grote groepen die met een letter zijn aangegeven. Het rotatieprincipe werkt zo dat in kwartaal II de respons a uit kwartaal I vervangen wordt door F, in kwartaal III de respons b uit kwartaal II vervangen door G, enz. Iedere groep wordt zodoende vijf keer gepeild. Van de oorspronkelijke groep in een kwartaal is een jaar later een vijfde over. De eerste_peiling volgt via CAPI: de vragenlijst wordt aan de respondent op zijn huisadres voorgelegd en de antwoorden worden door de enquêteur in de laptop ingevoerd. De vervolgpeilingen vinden via de telefoon plaats (CATI).

Een andere vorm van "uitval" ontstaat wanneer personen besluiten niet meer aan de enquête deel te nemen. Dit is wat we normaal gesproken onder paneluitval verstaan. Dit heeft tot gevolg dat niet van alle starters alle transities worden waargenomen. Een specifiek probleem doet zich voor wanneer de paneluitval selectief is. Of paneluitval gevolgen heeft voor de berekening van de beroepenmobiliteit in de EBB zal in hoofdstuk 4 worden onderzocht.

In de weging van de uitkomsten naar de populatie zal met de rotatie en non-respons zo goed mogelijk rekening gehouden moeten worden om onzuiverheden in de berekening van mobiliteit zo veel mogelijk te voorkomen. Het vaststellen van de weegfactoren voor een panel van steekproefpersonen is een onderwerp dat aparte aandacht vereiste. Dit heeft geleid tot een nieuw weegschema, dat is samengevat in bijlage 5 .

Schema 2: Rotatie panel EBB *)

\begin{tabular}{|c|c|c|c|c|c|}
\hline \multicolumn{6}{|c|}{ Kwartaal } \\
\hline IV & 1 & II & III & IV & $I$ \\
\hline$\underline{D}$ & $E$ & $\mathrm{~F}$ & G & $\mathrm{H}$ & I \\
\hline $\bar{C}$ & $\underline{\mathrm{d}}$ & e & $f$ & $g$ & $\mathrm{H}$ \\
\hline B & $\bar{C}$ & $\underline{\mathrm{d}}$ & e & $f$ & G \\
\hline \multirow[t]{2}{*}{$A$} & $b$ & $\bar{c}$ & $\underline{\mathrm{d}}$ & e & $\mathrm{F}$ \\
\hline & $\mathrm{a}$ & $b$ & $\bar{c}$ & $\underline{\mathrm{d}}$ & E \\
\hline
\end{tabular}

*) Hoofdletters:= eerste peiling volgens CAPI; 4 vervolgpeilingen:= kleine letters volgens CATI

Vragenlijst Ook de vragenlijst legt beperkingen op ten aanzien van de meting van beroepenmobiliteit. In de tweede (CATI) peiling, worden de werkkringen van de respondent opnieuw vastgesteld. Is de hoofdwerkkring gewijzigd, krijgt de respondent niet de vraag voorgelegd of zijn beroep (of functie) sinds de laatste keer (vorige peiling) is veranderd, maar wordt opnieuw het beroep vastgesteld op een manier zoals dat in de daaraan voorafgaande peiling is gebeurd. De zoekmachine bepaalt dan weer het beroep op basis van de eerder genoemde criteria. Op deze wijze kan de berekening van de beroepenmobiliteit zuiver worden toegepast door de twee SBC beroepen te vergelijken. Is de werkkring ongewijzigd volgens de respondent, dan krijgt hij/zij uitsluitend de vraag of beroep of functie nog dezelfde is als de laatste keer. Is het antwoord "ja", wordt de in de vorige peiling vastgestelde beroep(code) automatisch ingevuld.

Doordat het beroep niet opnieuw wordt vastgesteld voor deze respondenten volgens de bekende criteria, wordt ruis in de berekening van de beroepenmobiliteit voorkomen. Als bij iedere meting het beroep opnieuw zou worden gecodeerd dan kan dit leiden tot een te hoge berekening van de mobiliteit. Dit blijkt onder andere uit studies van Mathiowetz (1992) en Polivka en Rothgeb (1993). Aan de andere kant is een incorrecte codering van 
het beroep niet uit te sluiten wanneer de respondent in de vorige peiling van een ander beroep uitging dan door de zoekmachine was vastgesteld.

In schema 3 is op een vereenvoudigde manier aangegeven op welke wijze het beroep van een respondent en beroepenmobiliteit op basis van de EBB kan worden vastgesteld.

Schema 3: Vaststelling beroep(en mobiliteit) in de EBB (vereenvoudigde voorstelling)

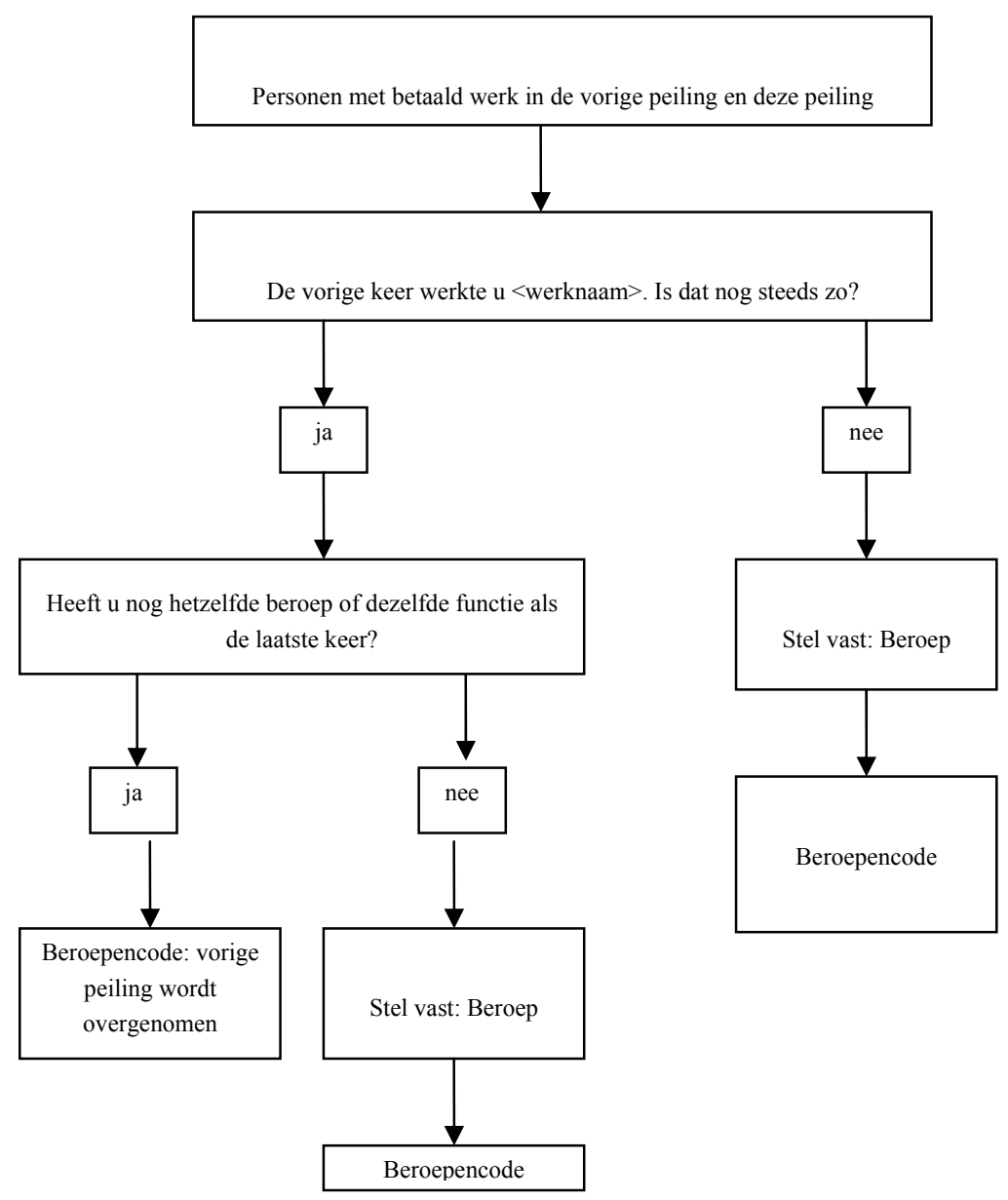

\section{Plausibiliteit EBB paneldata}

Bij panelonderzoek is de kwaliteit van de uitkomsten afhankelijk van de paneluitval. Is deze selectief omdat de uitval een afwijkend mobiliteitsgedrag vertoont dan zijn de uitkomsten over mobiliteit niet representatief. In dit hoofdstuk wordt nagegaan of er aanwijzingen zijn voor een dergelijke selectiviteit. Ook andere kwaliteitsaspecten van de uitkomsten komen aan de orde. In dit hoofdstuk gaat het om de kwaliteitsaspecten die samenhangen met:

1. uitval;

2. proxybeantwoording;

${ }^{7}$ Bijlage 1 bevat de uitgebreide weergave van de procesverantwoording van de EBB. 
3. verandering van beroep of werkkring.

\subsection{Uitval}

Totale groep Panelinformatie uit de EBB is beschikbaar vanaf verslagjaar 2000. De uitval voor de verslagjaren 2000 en 2001 is zo groot, dat de gegevens niet bruikbaar zijn voor een statistiek over beroepenmobiliteit. De EBB 2006 blijft eveneens buiten beschouwing. De reden hiervan is dat informatie over paneluitval in dat jaar nog niet volledig bekend is vanwege doorstroom naar 2007. Ten tijde van dit onderzoek waren nog geen gegevens over 2007 beschikbaar. We beperken ons derhalve tot de EBB jaren 2002 tot en met 2005.

Tabel 1 geeft een overzicht van het aantal respondenten per jaar en per peiling. Hieruit blijkt dat over de periode 2002-2005 in totaal 336 duizend personen hebben deelgenomen aan de eerste peiling. Hiervan neemt bijna vier van de vijf deel aan de tweede peiling. Dit aandeel loopt terug tot ruim tweederde bij de vijfde peiling.

Tabel 1: Aantal respondenten in de EBB, per peilnummer, 15-64 jaar, 2002-2005

\begin{tabular}{|l|c|c|}
\hline & & \\
\hline Peilnummer & x 1 000 & \% van $1^{\mathrm{e}}$ peiling \\
1 & 336 & 100 \\
2 & 262 & 78 \\
3 & 246 & 73 \\
4 & 233 & 69 \\
5 & 224 & 67 \\
\hline
\end{tabular}

De paneluitval naar de achtergrondkenmerken geslacht, herkomstgroepering, leeftijd en opleidingsniveau geven aan dat de uitval voor (tabellen B2.1-B2.6; bijlage 2):

- mannen en vrouwen vrijwel gelijk is;

- onder allochtonen groter is dan onder autochtonen, met name voor de nietwesterse allochtonen;

- voor de jongeren (15-24 jaar) naar verhouding hoog is;

- voor personen met een lager opleidingsniveau naar verhouding hoog is, in het bijzonder voor hen die uitsluitend basisonderwijs hebben behaald.

Het gevolg van de paneluitval is dat de groepen waarvan de paneluitval relatief hoog is, nu zijn ondervertegenwoordigd in de cijfers. Wanneer één van deze groepen meer of juist minder beroepenmobiliteit vertoont, geven de ongewogen cijfers een vertekening van de werkelijke beroepenmobiliteit. Van een dergelijke vertekening mag hier worden uitgegaan. Zo zullen jongeren vaker van beroep wisselen dan ouderen, hetgeen er op neerkomt dat beroepenmobiliteit wordt onderschat. Een en ander betekent dat weging van de uitkomsten naar de populatieaantallen in ieder geval per achtergrondkenmerk leeftijd en herkomstgroepering noodzakelijk zal zijn. 
Paneluitval kan ook selectief zijn wanneer de uitval direct samenhangt met beroepenmobiliteit (dus niet alleen op de waargenomen persoonskenmerken). Dit is het geval wanneer personen die van beroep veranderen ook vaker verhuizen en daardoor niet meer aan de enquête deelnemen. In de weging zal daarom voor verhuizingen moeten worden gecorrigeerd.

Beroep Beperken we ons tot de groep respondenten die een beroep hebben waarvan bekend de beroepencode bekend is, ontstaat een iets gunstiger beeld. Geselecteerd zijn uitsluitend personen met een beroep van 12 uur of meer om de analyse op substantiële banen te kunnen toepassen. Het 12-uurs criterium sluit aan bij het criterium zoals dat in de definitie van de werkzame beroepsbevolking wordt toegepast.

Van de 336 duizend personen uit de eerste peiling van de EBB is bij 243 duizend personen de beroepencode bekend (tabel 2). Van ongeveer 2,1 duizend personen is deze niet bekend en op 89 duizend personen niet van toepassing. Bij de laatste gaat het om personen zonder baan. In tabel 2 is ook van deze groep de paneluitval vermeld. Bij personen met een beroepencode is de paneluitval minder groot dan bij het totaal. De uitval is het hoogst onder de personen zonder baan.

Tabel 2: Aantal respondenten waarvan de beroepencode bekend en wekelijkse arbeidsduur 12 uur of meer is, per peilnummer, 15-64 jaar, 2002-2005

\begin{tabular}{|c|c|c|c|c|c|c|}
\hline \multirow[b]{2}{*}{ Peilnummer } & \multicolumn{6}{|c|}{ Beroepencode } \\
\hline & x 1000 & $\begin{array}{c}\% \text { van } 1^{e} \\
\text { peiling }\end{array}$ & x 1000 & $\begin{array}{c}\% \text { van } 1^{e} \\
\text { peiling }\end{array}$ & x 1000 & $\begin{array}{c}\% \text { van } 1^{e} \\
\text { peiling }\end{array}$ \\
\hline 1 & 243 & 100 & 2,1 & 100 & 89 & 100 \\
\hline 2 & 196 & 81 & 1,7 & 78 & 60 & 68 \\
\hline 3 & 185 & 76 & 1,7 & 77 & 54 & 61 \\
\hline 4 & 176 & 72 & 1,7 & 77 & 49 & 55 \\
\hline 5 & 169 & 70 & 1,7 & 77 & 45 & 51 \\
\hline
\end{tabular}

Bij de uitsplitsing van de uitval naar achtergrondkenmerken ontstaan nauwelijks nieuwe gezichtspunten (tabellen B2.9-B2.14; bijlage 2), zodat geconcludeerd kan worden dat weging van de uitkomsten noodzakelijk blijft om voor vertekening te corrigeren. Bij geslacht zijn er weinig verschillen in paneluitval. Opnieuw blijkt dat de paneluitval hoger is bij allochtonen dan autochtonen, en dan vooral onder de niet-westerse allochtonen. Daarnaast is de paneluitval relatief hoog onder 15-24 en 25-34 jarigen. Voor het opleidingsniveau geldt dat er meer uitval is onder de laagst opgeleiden (basisonderwijs).

Uitval naar peiling

De paneluitval zal in het algemeen groter zijn naarmate het aantal peilingen toeneemt. Dit kan betekenen dat de kwaliteit van de uitkomsten over beroepenmobiliteit met iedere volgende peiling slechter wordt. Om hiervan een indicatie te verkrijgen, is de beroepenmobiliteit tussen twee opeenvolgende peilingen onderzocht van alle personen die een beroep (met bekende beroepencode) hadden met wekelijkse arbeidsduur van 12 uur of meer. Omdat onderzoek naar de mobiliteit bij kleine baantjes van minder dan 12 uur per week voor bepaalde doeleinden toch interessant kan zijn, is in bijlage 3 ingegaan op de verschillen met personen die een baan hebben van 1 uur per week of meer. 
In tabel 3 is weergegeven hoeveel personen van beroepencode veranderen tussen twee opeenvolgende peilingen.

Tabel 3: Verandering van beroepencode per peiling op vijf digit niveau, 15-64 jaar, 2002-2005 (wekelijkse arbeidsduur 12 uur of meer)

\begin{tabular}{|l|c|c|}
\hline Verandering beroepencode & x 1 000 & \% van totale $N^{*}$ ) \\
\hline Peiling 1 - peiling 2 & 4,0 & 2,0 \\
Peiling 2 - peiling 3 & 3,9 & 2,1 \\
Peiling 3 - peiling 4 & 3,7 & 2,1 \\
Peiling 4 - peiling 5 & 3,3 & 2,0 \\
Totaal & 14,9 & \\
*) Het percentage personen met een verandering van beroepencode \\
(pilin 2
\end{tabular}

(peiling $2 \mathrm{t} / \mathrm{m}$ peiling 5 ; tabel 2 ).

Voor de periode 2002-2005 is van 14,9 duizend personen de beroepencode gewijzigd. Vanwege de paneluitval is het aantal veranderingen van beroepencode het hoogst tussen peiling 1 en peiling 2 en het laagst tussen peiling 4 en peiling 5 .

Om een beeld te krijgen in hoeverre de paneluitval van invloed is op de beroepenmobiliteit is in tabel 3 het percentage verandering van beroepencode vermeld. Hiertoe is het aantal personen dat van beroepencode is veranderd gedeeld door het totale aantal personen waarvan de beroepencode bekend is (tabel 2). Op grond van deze cijfers bestaat er geen serieuze aanwijzing voor het optreden van selectiviteit als het aantal peilingen toeneemt.

In de tabellen B2.15-B2.20 wordt de verandering van beroepencode weergeven voor een aantal achtergrondkenmerken (geslacht, herkomst, leeftijd en opleidingsniveau). Ook in de cijfers naar achtergrondkenmerken vinden we geen duidelijke aanwijzingen voor selectiviteit bij een toenemend aantal peilingen. Bij herkomst zijn bij niet-westerse allochtonen de percentages in de eerdere peilingen wat hoger dan in de latere peilingen. Hetzelfde geldt voor de verschillende opleidingsniveaus, maar hierbij speelt mee dat het aantal onbekenden behoorlijk toeneemt bij deze variabele bij de latere peilingen. Voorzichtigheid blijft geboden bij de uitkomsten over niet-westerse allochtonen. Nogmaals wordt op het belang van de weging gewezen, als middel om voor paneluitval te corrigeren.

\subsection{Proxy beantwoording}

In de EBB kunnen de vragen ook door een ander lid van het huishouden worden beantwoord (proxy beantwoording). Bij de proxy beantwoording is het de vraag of de persoon die de vragen beantwoordt, wel altijd goed op de hoogte is van de arbeidsmarktsituatie van degene waar de vragen betrekking op hebben. Dit zou van invloed kunnen zijn op de kwaliteit van de uitkomsten over beroepenmobiliteit. In tabel 4 zijn de antwoorden weergegeven van de combinaties zelf-zelf, zelf-proxy en proxyproxy in twee opeenvolgende peilingen. Met de categorie zelf-proxy wordt hier zowel "zelf-proxy" als "proxy-zelf" bedoeld. De percentages in tabel 4 liggen wat lager dan in tabel 3 omdat in tabel 4 gepercenteerd is op de gehele EBB-populatie, en in tabel 3 op uitsluitend de personen waarvan de beroepencode bekend is. Uit tabel 4 blijkt dat vooral in de latere peilingen de beroepenmobiliteit procentueel gezien iets hoger ligt bij zelfproxy. 
Tabel 4: Proxy beantwoording en verandering van beroepencode, 2002-2005

\begin{tabular}{|l|c|c|}
\hline & x 1000 & $\%$ \\
\hline Beantwoording peiling 1-peiling 2 & 1,7 & 1,5 \\
Beide zelf & 1,0 & 1,6 \\
Zelf en proxy & 1,3 & 1,6 \\
Beide proxy & & \\
Beantwoording peiling 2-peiling 3 & 1,6 & 1,7 \\
Beide zelf & 0,8 & 1,9 \\
Zelf en proxy & 1,5 & 1,6 \\
Beide proxy & & 1,6 \\
Beantwoording peiling 3-peiling 4 & 1,4 & 2,0 \\
Beide zelf & 0,8 & 1,6 \\
Zelf en proxy & 1,4 & 1,5 \\
Beide proxy & & 1,9 \\
Beantwoording peiling 4-peiling 5 & 1,2 & 1,6 \\
Beide zelf & 0,7 & \\
Zelf en proxy & 1,3 & \\
Beide proxy & & \\
\hline
\end{tabular}

Met andere woorden: als twee opeenvolgende peilingen door de persoon zelf en door een ander lid van een huishouden worden beantwoord, is de beroepenmobiliteit net even iets hoger. Waarschijnlijk speelt hier mee dat de categorie zelf-proxy uit een andere populatie bestaat dan de categorie 'beide zelf' of de categorie "beide proxy". Personen die werken zijn minder vaak thuis. Daarom is onder de categorie "beide proxy" het aandeel werkenden relatief hoog. Dit in tegenstelling tot de categorie "beide zelf" die relatief veel werklozen en inactieven ("non-participatie") bevat. Voor hen is de kans het grootst dat ze op beide peilmomenten thuis zijn. De categorie "zelf-proxy" zit hier tussenin. Hierin kunnen veel personen zitten waarvan tussen beide peilingen de arbeidsmarktpositie is veranderd, bijvoorbeeld personen die de eerste maal nog werkloos waren en de daaropvolgende peiling werkzaam zijn. Daarnaast is de invloed van de gevonden verschillen in tabel 4 op het resultaat minder groot omdat het veel vaker voorkomt dat de beide peilingen door eenzelfde persoon worden beantwoord ("beide zelf" of "beide proxy"). Er ontstaat een iets ander beeld als naar leeftijd en herkomst wordt onderscheiden (zie tabellen: B2.7 en B2.8 in bijlage 2). Met name bij de jongeren ligt het percentage dat verandert van beroepencode in geval van proxy beantwoording beduidend lager. Hier geldt echter dat veel van de jongeren in de categorie 'beide proxy' nog op school zitten en niet werkzaam zijn, waardoor hun beroepsmobiliteit lager uitvat.

\subsection{Verandering van werkkring of beroep}

Tussen beroepveranderingen en veranderingen van werkkring bestaat een samenhang. Dit is het geval wanneer een beroepverandering gepaard gaat met een werkkringverandering. We voeren ook hier weer de toets uit of tussen de peilingen het beeld hetzelfde blijft. 
Als de respondent van werkkring is veranderd, wordt opnieuw het beroep vastgesteld. Is de werkkring ongewijzigd, dan krijgt de respondent de vraag of het beroep/functie sinds de laatste keer is gewijzigd. Is het antwoord "ja", dan wordt ook van deze personen het beroep opnieuw vastgesteld.

In tabel 5 en 6 is de verandering van werkkring in relatie tot de verandering van beroep weergegeven. Dit is gedaan voor de EBB jaren 2003 (tabel 5) en 2004 (tabel 6). In 2004 is voor het eerst de zoekmachine in de EBB vragenlijst toegepast. Hiermee kan als bijproduct een eventueel effect van de introductie van de zoekmachine in de EBB vragenlijst op de cijfers worden vastgesteld.

Tabel 5: Verandering van werkkring en aantal/aandeel verandering van beroepencode (vijf digit), per peiling, 2003 (geen zoekmachine)

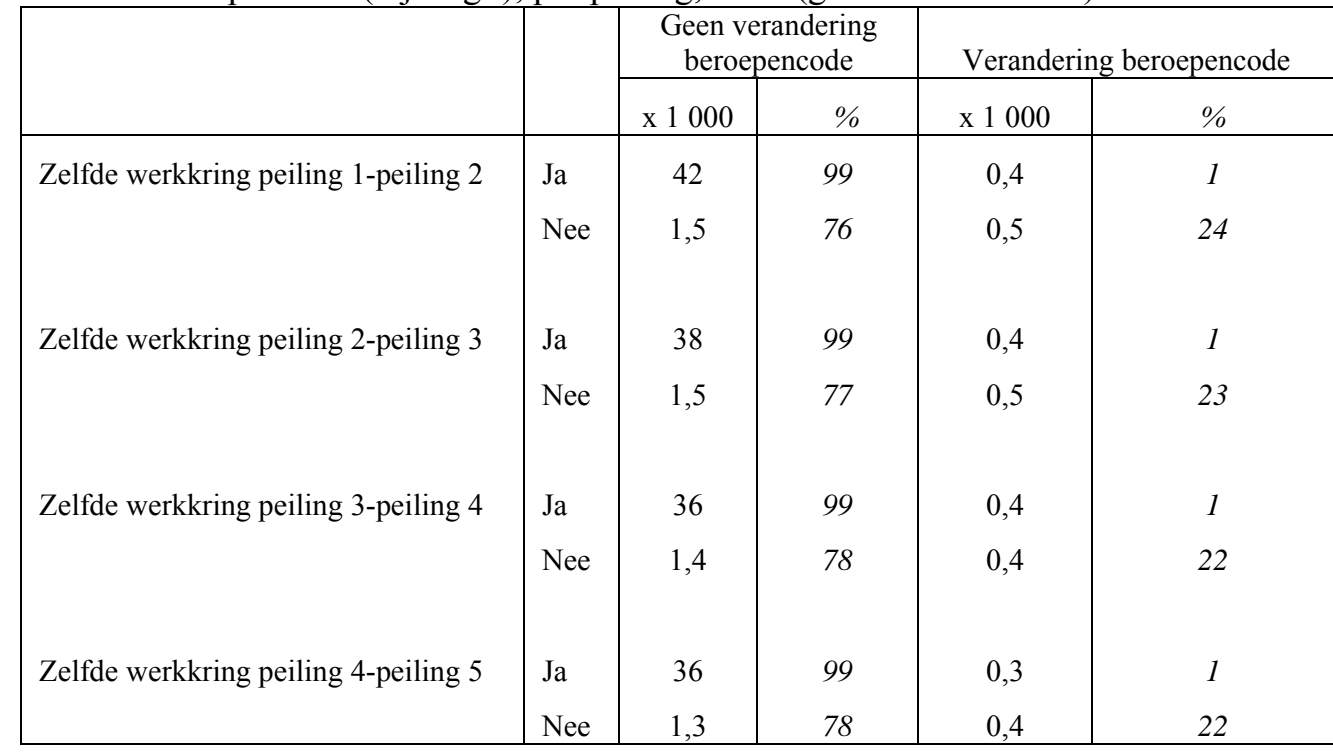

Uit tabel 5 blijkt dat in 2003 ongeveer een kwart van de personen die in de tweede peiling van werkkring is veranderd, ook van beroep is veranderd. In de latere peilingen ligt dit aandeel iets lager. Ook zijn er personen die binnen de huidige werkkring van beroep zijn veranderd. Het percentage blijft nagenoeg constant op 1 procent tussen de verschillende peilingen. De cijfers voor 2004 die in tabel 6 zijn weergegeven, wijken vrijwel niet af. Dit betekent dat de introductie van de zoekmachine bij de EBB 2004 geen negatieve invloed heeft gehad op de uitkomsten. 
Tabel 6: Verandering van werkkring en aantal/aandeel verandering van beroepencode (vijf digit), per peiling, 2004 (met zoekmachine)

\begin{tabular}{|c|c|c|c|c|c|}
\hline & & \multicolumn{2}{|c|}{$\begin{array}{c}\text { Geen verandering } \\
\text { beroepencode }\end{array}$} & \multicolumn{2}{|c|}{ Verandering beroepencode } \\
\hline $\begin{array}{l}\text { Zelfde werkkring als in vorige } \\
\text { peiling? }\end{array}$ & & x 1000 & $\%$ & x 1000 & $\%$ \\
\hline \multirow[t]{2}{*}{ Peiling 1-peiling 2} & $\mathrm{Ja}$ & 50 & 99 & 0,5 & 1 \\
\hline & Nee & 1,7 & 77 & 0,5 & 23 \\
\hline \multirow[t]{2}{*}{ Peiling 2-peiling 3} & $\mathrm{Ja}$ & 47 & 99 & 0,5 & 1 \\
\hline & Nee & 1,7 & 79 & 0,4 & 21 \\
\hline \multirow[t]{2}{*}{ Peiling 3-peiling 4} & $\mathrm{Ja}$ & 43 & 99 & 0,5 & 1 \\
\hline & Nee & 1,5 & 79 & 0,4 & 21 \\
\hline \multirow[t]{2}{*}{ Peiling 4-peiling 5} & $\mathrm{Ja}$ & 39 & 99 & 0,4 & 1 \\
\hline & Nee & 1,4 & 79 & 0,4 & 21 \\
\hline
\end{tabular}

Tabel 7: Verandering van beroep/functie en aantal/aandeel verandering van beroepencode (vijf digit)*, per peiling, 2003 (geen zoekmachine)

\begin{tabular}{|l|c|c|c|c|}
\hline \multirow{2}{*}{ Zelfde beroep/functie als in vorige peiling? } & \multicolumn{2}{|c|}{$\begin{array}{c}\text { Geen verandering } \\
\text { beroepencode }\end{array}$} & \multicolumn{2}{c|}{ Verandering beroepencode } \\
\cline { 2 - 5 } Peiling 1-peiling 2: Nee & $\mathrm{x} 1000$ & $\%$ & $\mathrm{x} 1000$ & $\%$ \\
Peiling 2-peiling 3: Nee & 0,2 & 45 & 0,3 & 55 \\
Peiling 3-peiling 4: Nee & 0,3 & 49 & 0,3 & 51 \\
Peiling 4-peiling 5: Nee & 0,2 & 41 & 0,3 & 51 \\
\hline
\end{tabular}

* Voor personen van wie de werkkring niet is veranderd.

Van personen die aangegeven van beroep/functie te zijn veranderd, wordt opnieuw het beroep bepaald. Onderzocht is of de mate waarin de nieuwe beroepencode voor deze personen verschilt van de beroepencode uit de vorige peiling afwijkt tussen 2003 en 2004. In 2003 (tabel 7) is van iets meer dan de helft van degenen die zeggen een ander beroep te hebben de beroepencode veranderd. In 2004 geldt dit voor ongeveer 60 procent van degenen die aangeven een ander beroep te hebben. Hiermee lijkt het er op dat er na de invoering van de zoekmachine, de mobiliteit hoger uitvalt voor degenen die zeggen 
van beroep te zijn veranderd (ongeveer 10 procent). Het gaat hierbij echter om relatief kleine absolute aantallen, zodat het effect op de berekende mobiliteit gering zal zijn.

Tabel 8: Verandering van beroep/functie en aantal/aandeel verandering van beroepencode (vijf digit)*, per peiling, 2004 (wel zoekmachine)

\begin{tabular}{|l|c|c|c|c|}
\hline & \multicolumn{2}{|c|}{$\begin{array}{c}\text { Geen verandering } \\
\text { beroepencode }\end{array}$} & \multicolumn{2}{|c|}{$\begin{array}{c}\text { Verandering } \\
\text { beroepencode }\end{array}$} \\
\hline Zelfde beroep/functie als in vorige peiling? & $\mathrm{x} 1000$ & $\%$ & $\mathrm{x} 1000$ & $\%$ \\
\hline Peiling 1-peiling 2: Nee & 0,2 & 36 & 0,3 & 64 \\
Peiling 2-peiling 3: Nee & 0,2 & 37 & 0,4 & 63 \\
Peiling 3-peiling 4: Nee & 0,2 & 42 & 0,3 & 58 \\
Peiling 4-peiling 5: Nee & 0,2 & 40 & 0,3 & 60 \\
\hline
\end{tabular}

* Voor personen van wie de werkkring niet is veranderd.

Niet uitgesloten is dat bepaalde personen vaker van baan wisselen en daarbij weer terugkeren naar het oude beroep. Het is echter ook mogelijk dat het beroep in een tussenliggende peiling niet helemaal goed is gemeten. In de daaropvolgende meting is het beroep dan weer goed gemeten, en men vindt deze persoon dan weer terug in het oorspronkelijke beroep. Dit zou een overschatting van de beroepenmobiliteit opleveren. Transities binnen een jaar naar het oorspronkelijke beroep kunnen echter geen substantieel verschijnsel zijn. Hierop is in deze paragraaf getoetst.

Uit tabel 9 blijkt dat terugkeer in het oorspronkelijke beroep inderdaad maar zeer weinig voorkomt. Van de 14,9 duizend personen die in de periode 2002-2005 van baan zijn veranderd zijn er slechts 312 weer teruggekeerd in het oorspronkelijke beroep (2 procent). Eventuele meetfouten op dit gebied zijn daarmee klein. Bovendien is dit ook bekeken wanneer beroepenmobiliteit op drie digit niveau wordt bepaald. In dat geval keert 3 procent terug in het oorspronkelijke beroep.

Tabel 9: Beroepenmobiliteit terug naar het oorspronkelijke beroep (vijf digit), 20022005

\begin{tabular}{|r|l|c|}
\hline & & N \\
\hline \multicolumn{1}{|l|}{ Totale beroepenmobiliteit } & & 14.900 \\
Waarvan terug in het oorspronkelijke beroep & Totaal & 312 \\
Waarvan tussen: & Peiling 1-Peiling 3 & 90 \\
& Peiling 2-Peiling 4 & 85 \\
& Peiling 1-Peiling 4 & 53 \\
& Peiling 2-Peiling 5 & 55 \\
& Peiling 1-Peiling 5 & 31 \\
\hline
\end{tabular}


Tabel 10: Beroepenmobiliteit terug naar het oorspronkelijke beroep (drie digit), 2002-2005

\begin{tabular}{|c|c|c|}
\hline & & $\mathrm{N}$ \\
\hline Totale beroepenmobiliteit & & 12.900 \\
\hline Waarvan terug in het oorspronkelijke beroep & Totaal & 364 \\
\hline Waarvan tussen: & Peiling 1-Peiling 3 & 114 \\
\hline & Peiling 2-Peiling 4 & 92 \\
\hline & Peiling 1-Peiling 4 & 60 \\
\hline & Peiling 2-Peiling 5 & 61 \\
\hline & Peiling 1-Peiling 5 & 37 \\
\hline
\end{tabular}

\section{Uitkomsten beroepenmobiliteit}

In het voorafgaande blijkt dat voor een groot aantal personen binnen het roterend EBBpanel een verandering van beroepscode wordt genoteerd op het 5 digit niveau. In dit hoofdstuk zal aandacht worden besteed aan in welke richting personen mobiel zijn en in hoeverre de grootte en richting van mobiliteitsstromen plausibel zijn. Niet alleen zal aandacht worden besteed aan mobiliteit tussen beroepen, maar ook aan mobiliteit vanuit en naar werkloosheid en non-participatie. Daarbij wordt de definitie van beroepenmobiliteit gebruikt zoals omschreven in hoofdstuk 3. De focus ligt op de uitstroom. Beroepverlaters kunnen uitstromen naar een nieuw beroep of stromen uit richting werkloosheid of non-participatie. Personen worden conform de CBS-definitie als werkloos beschouwd als zij tussen de leeftijd van 15 en 64 jaar zijn en niet of minder dan 12 uur per week werken en beschikbaar zijn en actief op zoek zijn naar een baan van 12 uur per week of meer. De groep non-participanten bestaat uit alle personen die niet 12 uur of meer werken en eveneens niet werkloos zijn. Het betreft personen die een baan hebben voor minder dan 12 uur maar niet meer uren willen werken, arbeidsongeschikt zijn, met pensioen zijn, zorgtaken op zich nemen etc.

De beroepenmobiliteit tussen de 5 peilingen van het ongewogen EBB-panelbestand wordt gemeten op 5-digit niveau, maar is getabelleerd op één digit, twee digit en drie digit niveau van de Standaard Beroepenclassificatie 1992 voor de periode 2002-2005. De steekproef is gelimiteerd tot personen met een leeftijd vanaf 15 jaar. $^{8}$ Aangezien het mogelijk is dat mensen doorwerken (bijvoorbeeld als zelfstandige) na hun $65^{\text {ste }}$, wordt er geen bovengrens gesteld aan de leeftijd. Net zoals bij de plausibiliteitsanalyse is gekozen om de jaren 2000 en 2001 buiten beschouwing te laten vanwege het grote paneluitval in deze twee jaren. De keuze om de mobiliteit niet op hogere digit niveaus te analyseren is ingegeven door het feit dat de mobiliteitsstromen, ondanks het substantiële aantal mobiele personen, te klein zijn tussen de 1.211 verschillende beroepen. Pas op een aggregatieniveau van 3 digit zijn de stromen groot genoeg voor een betrouwbare analyse

\footnotetext{
${ }^{8}$ Mensen die werkzaam zijn na de leeftijd van 65 jaar blijven in de steekproef terwijl nonparticipanten met een leeftijd van 65 jaar of ouder niet in de steekproef zijn opgenomen. Dit betekent dat de non-participatie in onze analyses wordt onderschat. Echter, de nadruk in deze studie ligt op mobiliteit tussen beroepen. Daarnaast treden de meeste werknemers uit voor hun $65^{\text {ste }}$.
} 
van de mobiliteit. Om het overzichtelijk te houden wordt in dit hoofdstuk alleen de beroepenmobiliteit op 1 digit niveau getoond. De beroepenmobiliteit op 3 digit niveau is opgenomen in bijlage 4.

Voor het bepalen van de beroepenmobiliteit is verder van belang dat respondenten de mogelijkheid hebben om eenmalig een peiling over te slaan. Als geen actie wordt ondernomen tegen de daarmee samenhangende non-respons in de tweede, derde en vierde peiling van het EBB panel, betekent dit dat waarnemingen van de twee omliggende peilingen eveneens niet bruikbaar zijn voor het bepalen van de mobiliteit. Voor deze publicatie is daarom gekozen om voor een eenmalige missende waarneming de in de vorige peiling geregistreerde beroepscode in te vullen.

\subsection{Beroepenmobiliteit in de EBB}

In tabel 11 wordt de beroepenmobiliteit over alle peilingen weergegeven op 1 digit niveau voor de periode 2002-2005. De rijen van de tabel geven het beroep waarin personen werkzaam zijn. Daarnaast kunnen personen werkloos of non-participant zijn. De kolommen geven weer in welk beroep personen werkzaam zijn in de volgende peiling volgens de 1 digit SBC van het CBS. Tevens kunnen beroepverlaters uitstromen naar werkloosheid en non-participatie. De tabel dient horizontaal te worden gelezen en telt over de rijen op tot $100 \%$.

Uit de tabel blijkt dat de uitstroom richting andere beroepen vrij laag is. Gemiddeld genomen blijft ongeveer 95\% van alle personen in het EBB-panel werkzaam in hetzelfde beroep. Dit percentage is hoger dan in het Sociaal Economisch Panel (zie tabel 12). Volgens de EBB is afhankelijk van de beroepsklasse 3 tot $11 \%$ van de werkzame personen mobiel, terwijl dit volgens het SEP 23 tot $45 \%$ is. De uitstroompercentages in het SEP zijn dus naar verhouding hoog. Hoewel dit geldt voor zowel de hogere als de lagere beroepen, is met name de mobiliteit bij de hogere beroepen opvallend. Zo zou 24 procent van de personen met een wetenschappelijk beroep (economisch) uitstromen naar een hoger administratief beroep. Volgens het SEP zou bij economen zelfs nog maar 53 procent een jaar later nog in hetzelfde beroep werken. Ook zou volgens het SEP 18 procent van de personen met een hoger administratief beroep naar een middelbaar administratief uitstromen. In de EBB zijn de uitstroompercentages bij de hogere beroepen veel lager en bij de lagere beroepen hoger, hetgeen meer in de lijn der verwachting ligt.

Er zijn vier mogelijke verklaringen voor de lagere mobiliteit in het EBB-panel.

- Op basis van de EBB wordt mobiliteit tussen beroepen gemeten tussen kwartalen, terwijl op basis van de SEP beroepenmobiliteit wordt gemeten tussen jaren. Aangezien werknemers doorgaans een aantal jaren werkzaam zijn bij dezelfde werkgever, is de beroepenmobiliteit tussen jaren groter dan tussen kwartalen. Dit blijkt ook uit tabel 13 waarin de mobiliteit tussen de eerste en de vijfde meting wordt weergegeven.

- $\quad$ De externe baanmobiliteit in Nederland was gedurende de periode 1995-2001 hoger dan in de periode 2002-2005. De externe baanmobiliteit is tussen 2001 en 2004 met ongeveer $6 \%$ gedaald. $^{9}$ Ook uit cijfers van het CBS (2008) dat de arbeidsmarktdynamiek tussen 2001 en 2004 een stuk lager was dan in die periode daarvoor de beroepenmobiliteit samenhangt met de baanmobiliteit

\footnotetext{
${ }^{9}$ Zie OSA (2006) voor een overzicht van externe baanmobiliteit voor de periode 1993-2004.
} 
impliceert dit dat de beroepenmobiliteit in de periode 2002-2005 eveneens lager zal zijn.

- In het SEP ontbreekt de terugkoppelvraag of men van beroep is veranderd, zoals die in de EBB wordt gesteld. Het beroep werd dus bij elke meting opnieuw vastgesteld in plaats van de vraag te stellen of het beroep ten opzichte van de vorige peiling is veranderd. In het SEP bestaat daarom een reële kans dat zowel de enquêteurs ("typeurvariantie") als respondenten ("respondentvariantie") anders kunnen oordelen over hetzelfde beroep in achtereenvolgende peilingen waardoor de beroepenmobiliteit wordt overschat. Studies van onder andere Mathiowetz (1992) en Polivka en Rothgeb (1993) tonen op basis van Amerikaanse data aan dat de vraagstellingwijze zoals in de SEP kan leiden tot een grote overschatting van de beroepenmobiliteit. Een recent literatuuroverzicht over het effect van de vraagstellingwijze op de meting van beroepenmobiliteit wordt gegeven door Moscarini en Thomsson (2007). Uit dit literatuuroverzicht blijkt dat de vraagstellingwijze grote effecten kan hebben op de gemeten beroepenmobiliteit. Moscarini en Thomson (2007) meten derhalve beroepenmobiliteit in de CPS op basis van vragen die ongeveer gelijk zijn aan die in de EBB. Qua orde van grootte sluit de gemeten beroepenmobiliteit in de CPS aan bij de beroepenmobiliteit op basis van het EBB-panel.

- Daarnaast is het goed denkbaar dat bij proxy beantwoording de overschatting in het SEP nog groter is. De proxy persoon zal vaak wel weten of er sprake van een beroepswijziging van de onderzoekspersoon, zoals dat bij de EBB gebeurt, maar niet precies het beroep van de onderzoekspersoon kunnen duiden (bij de SEP). 
Tabel 11: Beroep en arbeidsmarktpositie in de EBB tussen kwartalen $t$ en $t+1,2002-2005$ (ongewogen, 15-64 jaar)

\begin{tabular}{|c|c|c|c|c|c|c|c|c|c|c|c|c|}
\hline$n^{t+1}$ & $\begin{array}{c}\text { Elementaire } \\
\text { beroepen }\end{array}$ & $\begin{array}{l}\text { Lagere } \\
\text { Beroepen } \\
\text { (techniek } \\
\text { etc) }\end{array}$ & $\begin{array}{l}\text { Lagere adm., } \\
\text { commerciële } \\
\text { beroepen } \\
\text { e.d. }\end{array}$ & $\begin{array}{c}\text { Middelbare } \\
\text { beroepen } \\
\text { (techniek } \\
\text { etc) }\end{array}$ & $\begin{array}{l}\text { Middelbare } \\
\text { adm., } \\
\text { commerciële } \\
\text { beroepen } \\
\text { e.d. }\end{array}$ & $\begin{array}{c}\text { Hogere } \\
\text { beroepen } \\
\text { (techniek } \\
\text { etc) }\end{array}$ & $\begin{array}{c}\text { Hogere } \\
\text { adm., } \\
\text { commerciële } \\
\text { beroepen } \\
\text { e.d. }\end{array}$ & $\begin{array}{l}\text { Wetenschap- } \\
\text { pelijke } \\
\text { beroepen } \\
\text { (techniek } \\
\text { etc) }\end{array}$ & $\begin{array}{l}\text { Wetenschap- } \\
\text { pelijke } \\
\text { economische } \\
\text { adm. } \\
\text { beroepen } \\
\text { e.d. }\end{array}$ & $\begin{array}{l}\text { Werkloos- } \\
\text { heid }\end{array}$ & $\begin{array}{c}\text { Non- } \\
\text { participatie }\end{array}$ & $\begin{array}{c}\mathrm{N} \\
(\mathrm{x} 1000)\end{array}$ \\
\hline Elementaire beroepen & 89,2 & 0,9 & 0,9 & 0,4 & 0,6 & 0,1 & 0,1 & 0,0 & 0,0 & 1,8 & 6,0 & 43,9 \\
\hline $\begin{array}{l}\text { Lagere Beroepen (techniek } \\
\text { etc) }\end{array}$ & 0,4 & 95,3 & 0,2 & 0,6 & 0,2 & 0,1 & 0,1 & 0,0 & 0,0 & 1,0 & 2,1 & 83,8 \\
\hline $\begin{array}{l}\text { Lagere adm., commerciële } \\
\text { beroepen e.d. }\end{array}$ & 0,4 & 0,2 & 92,5 & 0,2 & 1,1 & 0,1 & 0,2 & 0,0 & 0,0 & 1,2 & 4,0 & 78,9 \\
\hline $\begin{array}{l}\text { Middelbare beroepen } \\
\text { (techniek etc) }\end{array}$ & 0,1 & 0,3 & 0,1 & 97,2 & 0,3 & 0,2 & 0,2 & 0,0 & 0,1 & 0,5 & 1,1 & 129,1 \\
\hline $\begin{array}{l}\text { Middelbare adm, } \\
\text { commerciële beroepen e.d. }\end{array}$ & 0,1 & 0,1 & 0,4 & 0,2 & 96,2 & 0,1 & 0,6 & 0,0 & 0,1 & 0,7 & 1,4 & 159,0 \\
\hline $\begin{array}{l}\text { Hogere beroepen (techniek } \\
\text { etc) }\end{array}$ & 0,0 & 0,0 & 0,1 & 0,3 & 0,2 & 97,1 & 0,4 & 0,2 & 0,1 & 0,3 & 1,2 & 71,1 \\
\hline $\begin{array}{l}\text { Hogere adm, commerciële } \\
\text { beroepen e.d. }\end{array}$ & 0,0 & 0,1 & 0,1 & 0,2 & 0,8 & 0,3 & 96,5 & 0,1 & 0,4 & 0,6 & 0,9 & 93,4 \\
\hline $\begin{array}{l}\text { Wetenschappelijke } \\
\text { beroepen (techniek etc) }\end{array}$ & 0,0 & 0,0 & 0,0 & 0,2 & 0,1 & 0,3 & 0,4 & 96,8 & 0,4 & 0,6 & 1,1 & 26,4 \\
\hline $\begin{array}{l}\text { Wetenschappelijke } \\
\text { economische adm. } \\
\text { beroepen e.d. }\end{array}$ & 0,0 & 0,0 & 0,1 & 0,1 & 0,4 & 0,2 & 1,0 & 0,3 & 96,7 & 0,4 & 0,9 & 36,0 \\
\hline Werkloosheid & 3,3 & 3,5 & 4,8 & 2,4 & 4,9 & 1,3 & 2,0 & 0,6 & 0,7 & 47,2 & 29,2 & 30,7 \\
\hline Non-participatie & 0,8 & 0,5 & 0,9 & 0,3 & 0,6 & 0,2 & 0,2 & 0,1 & 0,1 & 3,1 & 93,4 & 334,9 \\
\hline
\end{tabular}


De diagonaal van tabel 11 toont verder aan dat beroepenmobiliteit het grootst is bij de elementaire en lagere beroepen. Het is hierbij relevant om op te merken dat in de plausibiliteitanalyse is gebleken dat de uitval relatief groot is onder laagopgeleiden. Ervan uitgaande dat de uitval een positieve relatie heeft met mobiliteit, is het waarschijnlijk dat de mobiliteit van personen met een elementair of lager beroep wordt onderschat.

Bijna 11\% van de personen die werkzaam zijn in een elementair beroep stroomt uit in de volgende peiling. De meeste beroepverlaters die een elementair of lager beroep hadden stromen uit richting non-participatie en werkloosheid. Dit is weinig verrassend aangezien personen met een elementair beroep doorgaans een zwakke arbeidsmarktpositie hebben. Daarnaast werken veel studenten en scholieren naast hun studie in een elementair of lager beroep. Verder is de mobiliteit van werknemers met een elementair beroep beperkt tot uitstroom naar een lager beroep. De uitstroom van beroepverlaters naar middelbare en hogere beroepen is beperkt. Voor werknemers met een lager beroep geldt dat zij vooral uitstromen naar een elementair of middelbaar beroep. Bij de uitstroom naar een middelbaar beroep valt op dat de uitstroom voornamelijk naar beroepen gaat met dezelfde richting (op 1 digit niveau) als het initiële lagere beroep. Werknemers met een lager technisch, paramedisch transport of nietspecialistisch beroep stromen uit naar een middelbaar technisch, paramedisch transport of niet-specialistisch beroep. Werknemers met een lager administratief en commercieel beroep stromen vaker uit naar een middelbaar administratief en commercieel beroep.

De mobiliteit richting werkloosheid en non-participatie onder personen die een beroep op middelbaar of hoger niveau hebben is substantieel lager dan bij de elementaire en lagere beroepen. De beroepenmobiliteit voor mensen met een middelbaar of hoger beroep wordt gekenmerkt door mobiliteit naar een beroep in dezelfde richting op één niveau lager of hoger. Voor beroepen van het wetenschappelijk niveau geldt dat alleen mobiliteit naar een lager niveau mogelijk is. De meeste beroepverlaters met een wetenschappelijk beroep stromen uit richting een hoger beroep met dezelfde richting. Opvallend is echter dat $0,4 \%$ van de werkenden met een wetenschappelijk economisch administratief beroep in de volgende peiling werkzaam is in een middelbaar economisch administratief beroep.

Van de mensen die werkloos zijn, is $47 \%$ ook werkloos in de volgende kwartaalpeiling. Deze groep personen zal voor een groot gedeelte uit langdurig werklozen bestaan en mensen die meer moeite hebben om een baan te vinden die bij hun competenties past. Ongeveer $29 \%$ van de personen die werkloos zijn stroomt uit naar non-participatie. De uitstroom is het grootst naar beroepen met een economische of administratieve richting. Hierbij speelt dat het aantal baanopeningen in de economisch-administratieve beroepen groot is ten opzichte van de overige beroepen (zie ROA, 2007). Daarnaast leidt ook de verdienstelijking van de Nederlandse economie tot een verschuiving van werkgelegenheid van technische en industrieberoepen naar economisch-administratieve beroepen. 
Tabel 12: Beroep en arbeidsmarktpositie in het SEP tussen jaren $t$ en $t+1,1995-2001$ (ongewogen)

\begin{tabular}{|c|c|c|c|c|c|c|c|c|c|c|c|c|}
\hline$n^{t+1}$ & $\begin{array}{c}\text { Elementaire } \\
\text { beroepen }\end{array}$ & $\begin{array}{c}\text { Lagere } \\
\text { Beroepen } \\
\text { (techniek } \\
\text { etc) }\end{array}$ & $\begin{array}{c}\text { Lagere adm., } \\
\text { commerciële } \\
\text { beroepen } \\
\text { e.d. }\end{array}$ & $\begin{array}{l}\text { Middelbare } \\
\text { beroepen } \\
\text { (techniek } \\
\text { etc) }\end{array}$ & $\begin{array}{l}\text { Middelbare } \\
\text { adm., } \\
\text { commerciële } \\
\text { beroepen } \\
\text { e.d. }\end{array}$ & $\begin{array}{c}\text { Hogere } \\
\text { beroepen } \\
\text { (techniek } \\
\text { etc) }\end{array}$ & $\begin{array}{c}\text { Hogere } \\
\text { adm., } \\
\text { commerciële } \\
\text { beroepen } \\
\text { e.d. }\end{array}$ & $\begin{array}{l}\text { Wetenschap- } \\
\text { pelijke } \\
\text { beroepen } \\
\text { (techniek } \\
\text { etc) }\end{array}$ & $\begin{array}{c}\text { Wetenschap- } \\
\text { pelijke } \\
\text { economische } \\
\text { adm. } \\
\text { beroepen } \\
\text { e.d. }\end{array}$ & $\begin{array}{l}\begin{array}{l}\text { Werkloos- } \\
\text { heid }\end{array} \\
\text { n }\end{array}$ & $\begin{array}{c}\text { Non- } \\
\text { participatie }\end{array}$ & $\begin{array}{c}\mathrm{N} \\
(\mathrm{x} 1000)\end{array}$ \\
\hline Elementaire beroepen & 53,5 & 11,2 & 11,7 & 4,2 & 4,1 & 0,8 & 0,6 & 0,0 & 0,4 & 2,1 & 11,5 & 1,6 \\
\hline $\begin{array}{l}\text { Lagere Beroepen (techniek } \\
\text { etc) }\end{array}$ & 4,5 & 69,2 & 2,7 & 11,2 & 2,6 & 1,2 & 0,9 & 0,3 & 0,4 & 1,1 & 6,0 & 3,7 \\
\hline $\begin{array}{l}\text { Lagere adm., commerciële } \\
\text { beroepen e.d. }\end{array}$ & 5,1 & 2,7 & 57,1 & 2,1 & 18,5 & 0,7 & 2,5 & 0,3 & 0,5 & 1,6 & 8,8 & 3,7 \\
\hline $\begin{array}{l}\text { Middelbare beroepen } \\
\text { (techniek etc) }\end{array}$ & 1,4 & 11,4 & 2,3 & 67,6 & 5,2 & 4,0 & 2,7 & 1,0 & 0,6 & 0,5 & 3,4 & 3,5 \\
\hline $\begin{array}{l}\text { Middelbare adm, } \\
\text { commerciële beroepen e.d. }\end{array}$ & 1,2 & 1,9 & 13,1 & 3,1 & 62,1 & 1,8 & 9,8 & 0,6 & 1,8 & 1,0 & 3,6 & 5,2 \\
\hline $\begin{array}{l}\text { Hogere beroepen (techniek } \\
\text { etc) }\end{array}$ & 0,3 & 2,0 & 1,0 & 5,4 & 3,9 & 72,9 & 4,6 & 3,3 & 1,9 & 0,6 & 4,3 & 2,4 \\
\hline $\begin{array}{l}\text { Hogere adm, commerciële } \\
\text { beroepen e.d. }\end{array}$ & 0,4 & 1,1 & 2,6 & 3,3 & 18,4 & 3,8 & 58,7 & 0,8 & 6,7 & 1,1 & 3,0 & 2,7 \\
\hline $\begin{array}{l}\text { Wetenschappelijke } \\
\text { beroepen (techniek etc) }\end{array}$ & 0,0 & 1,3 & 0,6 & 6,4 & 4,2 & 16,1 & 6,1 & 59,2 & 4,0 & 0,3 & 1,8 & 0,6 \\
\hline $\begin{array}{l}\text { Wetenschappelijke } \\
\text { economische adm. } \\
\text { beroepen e.d. }\end{array}$ & 0,4 & 1,5 & 2,2 & 1,7 & 7,7 & 4,6 & 23,9 & 2,3 & 53,0 & 0,3 & 2,2 & 0,9 \\
\hline Werkloosheid & 4,3 & 5,6 & 9,0 & 3,0 & 8,0 & 2,7 & 2,8 & 0,5 & 1,0 & 25,7 & 37,3 & 1,2 \\
\hline Non-participatie & 1,9 & 1,9 & 3,3 & 1,1 & 1,9 & 0,7 & 0,7 & 0,2 & 0,2 & 3,9 & 84,2 & 12,6 \\
\hline
\end{tabular}


Tabel 13: Beroep en arbeidsmarktpositie in de EBB tussen eerste kwartaal $t$ en laatste kwartaal $t+4$ (1 digit), 2002-2005, (ongewogen)

\begin{tabular}{|c|c|c|c|c|c|c|c|c|c|c|c|c|}
\hline$n^{t+1}$ & $\begin{array}{l}\text { Elementaire } \\
\text { beroepen }\end{array}$ & $\begin{array}{c}\text { Lagere } \\
\text { Beroepen } \\
\text { (techniek } \\
\text { etc) }\end{array}$ & $\begin{array}{c}\text { Lagere adm., } \\
\text { commerciële } \\
\text { beroepen } \\
\text { e.d. }\end{array}$ & $\begin{array}{l}\text { Middelbare } \\
\text { beroepen } \\
\text { (techniek } \\
\text { etc) }\end{array}$ & $\begin{array}{l}\text { Middelbare } \\
\text { adm., } \\
\text { commerciële } \\
\text { beroepen } \\
\text { e.d. }\end{array}$ & $\begin{array}{c}\text { Hogere } \\
\text { beroepen } \\
\text { (techniek } \\
\text { etc) }\end{array}$ & $\begin{array}{c}\text { Hogere } \\
\text { adm., } \\
\text { commerciële } \\
\text { beroepen } \\
\text { e.d. }\end{array}$ & $\begin{array}{l}\text { Wetenschap- } \\
\text { pelijke } \\
\text { beroepen } \\
\text { (techniek } \\
\text { etc) }\end{array}$ & $\begin{array}{l}\text { Wetenschap- } \\
\text { pelijke } \\
\text { economische } \\
\text { adm. } \\
\text { beroepen } \\
\text { e.d. }\end{array}$ & $\begin{array}{l}\text { Werkloos- } \\
\text { heid }\end{array}$ & $\begin{array}{c}\text { Non- } \\
\text { participatie }\end{array}$ & $\begin{array}{c}\mathrm{N} \\
(\mathrm{x} 1000)\end{array}$ \\
\hline Elementaire beroepen & 77,5 & 2,5 & 3,0 & 1,5 & 2,0 & 0,2 & 0,4 & 0,1 & 0,0 & 2,7 & 10,0 & 10,5 \\
\hline $\begin{array}{l}\text { Lagere Beroepen (techniek } \\
\text { etc) }\end{array}$ & 1,2 & 88,7 & 0,8 & 2,2 & 0,8 & 0,2 & 0,2 & 0,0 & 0,1 & 1,5 & 4,2 & 20,8 \\
\hline $\begin{array}{l}\text { Lagere adm., commerciële } \\
\text { beroepen e.d. }\end{array}$ & 1,2 & 0,8 & 82,7 & 0,7 & 3,9 & 0,3 & 0,7 & 0,1 & 0,1 & 2,0 & 7,4 & 19,0 \\
\hline $\begin{array}{l}\text { Middelbare beroepen } \\
\text { (techniek etc) }\end{array}$ & 0,4 & 0,9 & 0,4 & 91,8 & 1,1 & 0,9 & 0,5 & 0,1 & 0,2 & 0,9 & 2,7 & 32,4 \\
\hline $\begin{array}{l}\text { Middelbare adm, } \\
\text { commerciële beroepen e.d. }\end{array}$ & 0,3 & 0,3 & 1,4 & 0,8 & 89,2 & 0,5 & 2,2 & 0,1 & 0,4 & 1,4 & 3,3 & 39,3 \\
\hline $\begin{array}{l}\text { Hogere beroepen (techniek } \\
\text { etc) }\end{array}$ & 0,1 & 0,1 & 0,2 & 0,9 & 0,8 & 91,6 & 1,5 & 0,7 & 0,5 & 0,7 & 2,9 & 17,6 \\
\hline $\begin{array}{l}\text { Hogere adm, commerciële } \\
\text { beroepen e.d. }\end{array}$ & 0,1 & 0,2 & 0,4 & 0,6 & 2,8 & 1,0 & 89,2 & 0,4 & 1,5 & 1,2 & 2,6 & 22,9 \\
\hline $\begin{array}{l}\text { Wetenschappelijke } \\
\text { beroepen (techniek etc) }\end{array}$ & 0,1 & 0,1 & 0,1 & 0,6 & 0,5 & 1,0 & 1,5 & 90,1 & 1,8 & 1,3 & 3,0 & 6,5 \\
\hline $\begin{array}{l}\text { Wetenschappelijke } \\
\text { economische adm. } \\
\text { beroepen e.d. }\end{array}$ & 0,0 & 0,1 & 0,3 & 0,4 & 1,4 & 0,8 & 3,6 & 0,9 & 89,0 & 0,9 & 2,6 & 8,9 \\
\hline Werkloosheid & 5,3 & 5,8 & 8,4 & 4,1 & 8,9 & 2,4 & 3,4 & 1,1 & 1,4 & 26,8 & 32,4 & 7,9 \\
\hline Non-participatie & 1,6 & 1,2 & 2,3 & 1,0 & 1,6 & 0,6 & 0,6 & 0,2 & 0,2 & 3,3 & 87,5 & 83,5 \\
\hline
\end{tabular}


Van de mensen die niet participeerden blijft 93\% non-participant. Het betreft hier voornamelijk personen die met pensioen zijn, studenten en mensen die zorgtaken op zich nemen in het huishouden. Het percentage niet-mobiele non-participanten is hoger dan in OSA-Arbeidsaanbodpanel $(80 \%)$. Echter, het OSA-Arbeidsaanbodpanel wordt om de twee jaar afgenomen, terwijl op basis van het EBB-panel de mobiliteit wordt gemeten tussen kwartalen, waardoor in de OSA-data een grotere mobiliteit wordt gemeten. Mensen die opnieuw gaan werken (herintreders) zijn vooral werkzaam in elementaire, lagere en middelbare beroepen. Net zoals bij de uitstroom vanuit werkloosheid is de uitstroom vanuit non-participatie het grootst naar beroepen met een economisch-administratieve richting.

De gevonden mobiliteitspatronen zijn zeer constant over de periode 2002-2005 en over de verschillende peilingen. Bijlage 5 geeft een overzicht van de mobiliteitspatronen voor elk jaar en voor elke peiling. Het enige verschil dat wordt gevonden is dat de uitstroom van personen met een elementaire en lagere beroepen richting non-participatie licht is gedaald vanaf 2004 en dat zij vaker werkzaam bleven in hetzelfde beroep. Waarschijnlijk is dit een conjunctuureffect. De jaren 2002-2003 werden gekenmerkt door laagconjunctuur. Vanaf 2004 is er sprake van conjunctureel herstel waardoor de arbeidsmarktpositie van laaggeschoolden is verbeterd (CPB, 2007).

Zoals reeds eerder gezegd wordt vanwege presentatieredenen en celvulling alleen de beroepenmobiliteit op 1 digit niveau getoond. De mogelijkheid bestaat echter dat werknemers niet mobiel zijn op het 1 digit niveau, maar wel van beroep veranderen op 5 digit niveau. De vraag is dus in welke mate beroepenmobiliteit niet wordt waargenomen op het 1 digit niveau. Tabel 14 geeft eerst het percentage werknemers dat niet mobiel is tussen beroepen op 1 digit niveau. In de tweede kolom wordt vervolgens per 1 digit beroepsklasse het percentage werknemers weergegeven dat niet mobiel is op het 5 digit niveau.

Tabel 14: 5 digit mobiliteit tussen beroepen binnen 1 digit niveau (in procenten) in de EBB tussen kwartalen $t$ en $t+1,2002-2005$ (ongewogen)

\begin{tabular}{lcccc}
\hline \hline & $\begin{array}{c}\text { Percentage niet } \\
\text { mobiel }(1 \\
\text { digit }\end{array}$ & $\begin{array}{c}\text { Percentage niet } \\
\text { mobiel }(5 \\
\text { digit }\end{array}$ & $\begin{array}{c}\text { Percentage } \\
\text { mobiel binnen } \\
\text { beroepsklassen } \\
\text { op 1 digit } \\
\text { niveau }\end{array}$ & $\begin{array}{c}\text { Percentage } \\
\text { mobiel tussen } \\
\text { beroepsklassen } \\
\text { op 1 digit } \\
\text { niveau }\end{array}$ \\
\hline Elementaire beroepen & 89,2 & 88,2 & 1,0 & 3,0 \\
Lagere Beroepen & 95,3 & 94,3 & 1,0 & 2,3 \\
Lagere adm., commerciële beroepen e.d. & 92,5 & 91,5 & 1,0 \\
Middelbare beroepen & 97,2 & 96,1 & 1,1 & 1,2 \\
$\begin{array}{l}\text { Middelbare adm, commerciële beroepen } \\
\text { e.d. }\end{array}$ & 96,2 & 95,1 & 1,1 & 1,7 \\
Hogere beroepen & 97,1 & 96,1 & 1,0 & 1,3 \\
Hogere adm, commerciële beroepen e.d. & 96,5 & 95,4 & 1,1 & 1,9 \\
Wetenschappelijke beroepen & 96,8 & 95,8 & 1,0 \\
$\begin{array}{l}\text { Wetenschappelijke economische adm. } \\
\text { beroepen e.d. }\end{array}$ & 96,7 & 95,6 & 1,1 \\
\hline \hline
\end{tabular}


Tabel 15: Beroep en arbeidsmarktpositie tussen kwartalen $t$ en $t+1$ van mannen (1 digit), 2002-2005 (ongewogen)

\begin{tabular}{|c|c|c|c|c|c|c|c|c|c|c|c|c|}
\hline$n^{t+1}$ & $\begin{array}{c}\text { Elementaire } \\
\text { beroepen }\end{array}$ & $\begin{array}{c}\text { Lagere } \\
\text { Beroepen } \\
\text { (techniek } \\
\text { etc) }\end{array}$ & $\begin{array}{c}\text { Lagere adm., } \\
\text { commerciële } \\
\text { beroepen } \\
\text { e.d. }\end{array}$ & $\begin{array}{c}\text { Middelbare } \\
\text { beroepen } \\
\text { (techniek } \\
\text { etc) }\end{array}$ & $\begin{array}{l}\text { Middelbare } \\
\text { adm., } \\
\text { commerciële } \\
\text { beroepen } \\
\text { e.d. }\end{array}$ & $\begin{array}{c}\text { Hogere } \\
\text { beroepen } \\
\text { (techniek } \\
\text { etc) }\end{array}$ & $\begin{array}{l}\text { Hogere } \\
\text { adm., } \\
\text { commerciële } \\
\text { beroepen } \\
\text { e.d. }\end{array}$ & $\begin{array}{l}\text { Wetenschap- } \\
\text { pelijke } \\
\text { beroepen } \\
\text { (techniek } \\
\text { etc) }\end{array}$ & $\begin{array}{l}\text { Wetenschap- } \\
\text { pelijke } \\
\text { economische } \\
\text { adm. } \\
\text { beroepen } \\
\text { e.d. }\end{array}$ & $\begin{array}{l}\text { Werkloos- } \\
\text { heid }\end{array}$ & $\begin{array}{c}\text { Non- } \\
\text { participatie }\end{array}$ & $\begin{array}{c}\mathrm{N} \\
(\mathrm{x} 1000)\end{array}$ \\
\hline Elementaire beroepen & 89,5 & 1,3 & 0,7 & 0,6 & 0,6 & 0,1 & 0,2 & 0,0 & 0,0 & 1,8 & 5,3 & 23,7 \\
\hline $\begin{array}{l}\text { Lagere Beroepen (techniek } \\
\text { etc) }\end{array}$ & 0,4 & 96,0 & 0,1 & 0,6 & 0,2 & 0,0 & 0,1 & 0,0 & 0,0 & 0,9 & 1,7 & 70,5 \\
\hline $\begin{array}{l}\text { Lagere adm., commerciele } \\
\text { beroepen e.d. }\end{array}$ & 0,6 & 0,4 & 92,4 & 0,3 & 1,4 & 0,1 & 0,3 & 0,0 & 0,1 & 1,2 & 3,2 & 20,7 \\
\hline $\begin{array}{l}\text { Middelbare beroepen } \\
\text { (techniek etc) }\end{array}$ & 0,1 & 0,3 & 0,1 & 97,4 & 0,3 & 0,2 & 0,2 & 0,0 & 0,0 & 0,5 & 0,9 & 90,5 \\
\hline $\begin{array}{l}\text { Middelbare adm, } \\
\text { commerciele beroepen e.d. }\end{array}$ & 0,1 & 0,1 & 0,3 & 0,3 & 96,4 & 0,1 & 0,7 & 0,0 & 0,1 & 0,6 & 1,1 & 70,6 \\
\hline $\begin{array}{l}\text { Hogere beroepen (techniek } \\
\text { etc) }\end{array}$ & 0,0 & 0,1 & 0,0 & 0,3 & 0,2 & 97,1 & 0,6 & 0,2 & 0,2 & 0,3 & 0,9 & 32,9 \\
\hline $\begin{array}{l}\text { Hogere adm, commerciele } \\
\text { beroepen e.d. }\end{array}$ & 0,0 & 0,1 & 0,1 & 0,2 & 0,6 & 0,2 & 96,9 & 0,1 & 0,4 & 0,6 & 0,8 & 60,2 \\
\hline $\begin{array}{l}\text { Wetenschappelijke } \\
\text { beroepen (techniek etc) }\end{array}$ & 0,0 & 0,0 & 0,0 & 0,2 & 0,1 & 0,4 & 0,4 & 97,0 & 0,4 & 0,5 & 0,9 & 16,5 \\
\hline $\begin{array}{l}\text { Wetenschappelijke } \\
\text { economische adm. } \\
\text { beroepen e.d. }\end{array}$ & 0,0 & 0,0 & 0,1 & 0,1 & 0,4 & 0,2 & 1,1 & 0,2 & 96,7 & 0,4 & 0,9 & 23,2 \\
\hline Werkloosheid & 4,2 & 6,5 & 2,6 & 3,8 & 3,8 & 1,0 & 2,6 & 0,8 & 0,8 & 51,1 & 22,8 & 13,5 \\
\hline Non-participatie & 1,3 & 1,0 & 0,7 & 0,5 & 0,5 & 0,1 & 0,3 & 0,1 & 0,1 & 3,1 & 92,5 & 115,2 \\
\hline
\end{tabular}


Tabel 16: Beroep en arbeidsmarktpositie tussen kwartalen $t$ en $t+1$ van vrouwen (1 digit), 2002-2005 (ongewogen)

\begin{tabular}{|c|c|c|c|c|c|c|c|c|c|c|c|c|}
\hline$n^{t+1}$ & $\begin{array}{c}\text { Elementaire } \\
\text { beroepen }\end{array}$ & $\begin{array}{l}\text { Lagere } \\
\text { Beroepen } \\
\text { (techniek } \\
\text { etc) }\end{array}$ & $\begin{array}{c}\text { Lagere adm., } \\
\text { commerciële } \\
\text { beroepen } \\
\text { e.d. }\end{array}$ & $\begin{array}{l}\text { Middelbare } \\
\text { beroepen } \\
\text { (techniek } \\
\text { etc) }\end{array}$ & $\begin{array}{l}\text { Middelbare } \\
\text { adm., } \\
\text { commerciële } \\
\text { beroepen } \\
\text { e.d. }\end{array}$ & $\begin{array}{c}\text { Hogere } \\
\text { beroepen } \\
\text { (techniek } \\
\text { etc) }\end{array}$ & $\begin{array}{c}\text { Hogere } \\
\text { adm., } \\
\text { commerciële } \\
\text { beroepen } \\
\text { e.d. }\end{array}$ & $\begin{array}{l}\text { Wetenschap- } \\
\text { pelijke } \\
\text { beroepen } \\
\text { (techniek } \\
\text { etc) }\end{array}$ & $\begin{array}{l}\text { Wetenschap- } \\
\text { pelijke } \\
\text { economische } \\
\text { adm. } \\
\text { beroepen } \\
\text { e.d. }\end{array}$ & $\begin{array}{l}\text { Werkloos- } \\
\text { heid }\end{array}$ & $\begin{array}{c}\text { Non- } \\
\text { participatie }\end{array}$ & $\begin{array}{c}\mathrm{N} \\
(\mathrm{x} 1000)\end{array}$ \\
\hline Elementaire beroepen & 90,2 & 0,4 & 1,2 & 0,2 & 0,6 & 0,1 & 0,1 & 0,0 & 0,0 & 1,7 & 5,4 & 19,2 \\
\hline $\begin{array}{l}\text { Lagere Beroepen (techniek } \\
\text { etc) }\end{array}$ & 0,4 & 92,0 & 0,7 & 0,8 & 0,5 & 0,1 & 0,1 & 0,0 & 0,0 & 1,5 & 3,8 & 11,9 \\
\hline $\begin{array}{l}\text { Lagere adm., commerciele } \\
\text { beroepen e.d. }\end{array}$ & 0,3 & 0,1 & 93,0 & 0,2 & 1,1 & 0,1 & 0,1 & 0,0 & 0,0 & 1,2 & 3,7 & 56,3 \\
\hline $\begin{array}{l}\text { Middelbare beroepen } \\
\text { (techniek etc) }\end{array}$ & 0,1 & 0,1 & 0,2 & 96,8 & 0,5 & 0,3 & 0,1 & 0,0 & 0,1 & 0,4 & 1,4 & 36,3 \\
\hline $\begin{array}{l}\text { Middelbare adm, } \\
\text { commerciele beroepen e.d. }\end{array}$ & 0,1 & 0,1 & 0,5 & 0,2 & 96,0 & 0,1 & 0,5 & 0,0 & 0,1 & 0,8 & 1,5 & 85,4 \\
\hline $\begin{array}{l}\text { Hogere beroepen (techniek } \\
\text { etc) }\end{array}$ & 0,0 & 0,0 & 0,1 & 0,2 & 0,2 & 97,2 & 0,3 & 0,1 & 0,1 & 0,3 & 1,4 & 36,9 \\
\hline $\begin{array}{l}\text { Hogere adm, commerciele } \\
\text { beroepen e.d. }\end{array}$ & 0,0 & 0,1 & 0,2 & 0,1 & 1,1 & 0,4 & 95,7 & 0,1 & 0,4 & 0,7 & 1,2 & 31,0 \\
\hline $\begin{array}{l}\text { Wetenschappelijke } \\
\text { beroepen (techniek etc) }\end{array}$ & 0,0 & 0,0 & 0,0 & 0,2 & 0,1 & 0,3 & 0,4 & 96,5 & 0,5 & 0,7 & 1,3 & 9,3 \\
\hline $\begin{array}{l}\text { Wetenschappelijke } \\
\text { economische adm. } \\
\text { beroepen e.d. }\end{array}$ & 0,0 & 0,0 & 0,1 & 0,1 & 0,4 & 0,2 & 0,9 & 0,3 & 96,6 & 0,6 & 0,8 & 11,9 \\
\hline Werkloosheid & 2,7 & 1,2 & 6,5 & 1,3 & 5,8 & 1,6 & 1,5 & 0,5 & 0,6 & 44,2 & 34,1 & 17,2 \\
\hline Non-participatie & 0,5 & 0,2 & 1,1 & 0,2 & 0,6 & 0,2 & 0,1 & 0,1 & 0,0 & 3,1 & 93,8 & 219,7 \\
\hline
\end{tabular}


Het blijkt dat maar ruwweg $1 \%$ van de werknemers voor wie geen mobiliteit wordt waargenomen op het 1 digit niveau, wel mobiel is op het 5 digit niveau. Daarmee is de mobiliteit op 5 digit niveau binnen eenzelfde beroepsgroep dus kleiner dan de mobiliteit tussen beroepsgroepen.

\subsection{Beroepenmobiliteit naar achtergrondkenmerken}

Om de plausibiliteit van de beroepenmobiliteit nader te onderzoeken is de mobiliteit verder uitgesplitst naar achtergrondkenmerken van personen. Allereerst is gekeken naar de mobiliteit van mannen en vrouwen. Op basis van gegevens over externe baanmobiliteit en functiemobiliteit in OSA (2006) kan verwacht worden dat de vrouwen iets mobieler zijn dan mannen.

De tabellen 15 en 16 tonen aan dat de beroepenmobiliteit van vrouwen in het EBB panel slechts in beperkte mate groter is dan voor mannen. Het verschil tussen mannen en vrouwen is met $4,0 \%$ het grootst bij de lagere beroepen. Daarnaast blijkt dat de mobiliteit van vrouwen richting non-participatie eveneens enigszins groter is dan voor mannen. Dit geldt echter niet voor vrouwen die werkzaam zijn in een wetenschappelijk economisch en administratief beroep. Zoals te verwachten valt is het percentage vrouwen dan non-participant blijft met 93,8\% hoger dan het percentage mannen $(92,5 \%)$. Mannen blijven vaker werkloos, terwijl vrouwen vaker vanuit werkloosheid uitstromen richting non-participatie. Daarnaast blijkt dat vrouwen vaker doorstromen vanuit werkloosheid naar lagere en middelbare economische en administratieve beroepen dan mannen. Mannen stromen vaker uit naar lagere beroepen en middelbare beroepen.

Vervolgens is de mobiliteit vergeleken tussen de verschillende leeftijdsgroepen. Verwacht kan worden dat jongeren vanwege hun zwakke arbeidsmarktpositie vaker werkloos en mobiel zijn tussen banen. Daarnaast zullen veel jongeren bijverdiensten hebben naast hun studie. Als jongeren meer tijd aan hun studie gaan besteden, dan zullen zij volgens de CBS-definitie worden beschouwd als non-participant. Derhalve kan verwacht worden dat de mobiliteit richting non-participatie onder jongeren groter is dan onder ouderen. Dit geldt specifiek voor laagopgeleide jongeren zonder startkwalificatie die vaak alsnog een vervolgstudie gaan doen. Voor ouderen kan worden verwacht dat zij als gevolg van (vervroegde) pensionering vaker zullen uittreden uit de arbeidsmarkt.

De tabellen 17 tot en met 21 geven de mobiliteit weer voor verschillende leeftijdsklassen. Tabel 17 laat zien dat de mobiliteit onder 15-24 jarigen conform de verwachting hoger is. Specifiek voor elementaire beroepen en lagere beroepen geldt dat de mobiliteit zeer hoog is. Ook valt af te lezen dat de mobiliteit groter is voor beroepen met een economische inslag, ongeacht het niveau.

Veel 15-24 jarigen vertrekken van de arbeidsmarkt. Bijna 18\% van de 15-24 jarigen die werkzaam waren in een elementair beroep, is in de volgende periode nonparticipant. Ook 15-24 jarigen die werkzaam waren in een lager administratief, commercieel en economisch beroep treden vaak uit van de arbeidsmarkt (12,1\%). De mobiliteit richting werkloosheid onder deze leeftijdsgroep is eveneens veel groter dan voor andere leeftijdsgroepen. Echter, het percentage mensen dat werkloos of nonparticipant blijft in de volgende periode is kleiner voor deze groep dan voor andere leeftijdsgroepen. 
Tabel 17: Beroep en arbeidsmarktpositie tussen kwartalen $t$ en $t+1$ van 15-24 jarigen (1 digit), 2002-2005 (ongewogen)

\begin{tabular}{|c|c|c|c|c|c|c|c|c|c|c|c|c|}
\hline$n^{t+1}$ & $\begin{array}{c}\text { Elementaire } \\
\text { beroepen }\end{array}$ & $\begin{array}{c}\text { Lagere } \\
\text { Beroepen } \\
\text { (techniek } \\
\text { etc) }\end{array}$ & $\begin{array}{c}\text { Lagere adm., } \\
\text { commerciële } \\
\text { beroepen } \\
\text { e.d. }\end{array}$ & $\begin{array}{c}\text { Middelbare } \\
\text { beroepen } \\
\text { (techniek } \\
\text { etc) }\end{array}$ & $\begin{array}{l}\text { Middelbare } \\
\text { adm., } \\
\text { commerciële } \\
\text { beroepen } \\
\text { e.d. }\end{array}$ & $\begin{array}{c}\text { Hogere } \\
\text { beroepen } \\
\text { (techniek } \\
\text { etc) }\end{array}$ & $\begin{array}{l}\text { Hogere } \\
\text { adm., } \\
\text { commerciële } \\
\text { beroepen } \\
\text { e.d. }\end{array}$ & $\begin{array}{l}\text { Wetenschap- } \\
\text { pelijke } \\
\text { beroepen } \\
\text { (techniek } \\
\text { etc) }\end{array}$ & $\begin{array}{l}\text { Wetenschap- } \\
\text { pelijke } \\
\text { economische } \\
\text { adm. } \\
\text { beroepen } \\
\text { e.d. }\end{array}$ & $\begin{array}{l}\text { Werkloos- } \\
\text { heid }\end{array}$ & $\begin{array}{c}\text { Non- } \\
\text { participatie }\end{array}$ & $\begin{array}{c}\mathrm{N} \\
(\mathrm{x} 1000)\end{array}$ \\
\hline Elementaire beroepen & 72,8 & 2,0 & 2,1 & 0,7 & 1,0 & 0,2 & 0,2 & 0,1 & 0,0 & 3,1 & 17,8 & 9,4 \\
\hline $\begin{array}{l}\text { Lagere Beroepen (techniek } \\
\text { etc) }\end{array}$ & 1,2 & 86,8 & 0,8 & 1,5 & 0,4 & 0,1 & 0,1 & 0,0 & 0,0 & 2,1 & 7,0 & 10,9 \\
\hline $\begin{array}{l}\text { Lagere adm., commerciele } \\
\text { beroepen e.d. }\end{array}$ & 0,9 & 0,5 & 81,5 & 0,3 & 2,0 & 0,1 & 0,3 & 0,0 & 0,1 & 2,2 & 12,1 & 16,2 \\
\hline $\begin{array}{l}\text { Middelbare beroepen } \\
\text { (techniek etc) }\end{array}$ & 0,4 & 0,7 & 0,5 & 93,0 & 0,5 & 0,3 & 0,1 & 0,0 & 0,0 & 1,2 & 3,2 & 9,6 \\
\hline $\begin{array}{l}\text { Middelbare adm, } \\
\text { commerciele beroepen e.d. }\end{array}$ & 0,4 & 0,2 & 1,4 & 0,4 & 89,5 & 0,2 & 0,8 & 0,1 & 0,1 & 1,8 & 5,0 & 11,6 \\
\hline $\begin{array}{l}\text { Hogere beroepen (techniek } \\
\text { etc) }\end{array}$ & 0,1 & 0,1 & 0,3 & 0,5 & 0,6 & 92,3 & 0,3 & 0,4 & 0,1 & 1,2 & 4,2 & 2,7 \\
\hline $\begin{array}{l}\text { Hogere adm, commerciele } \\
\text { beroepen e.d. }\end{array}$ & 0,3 & 0,2 & 1,0 & 0,3 & 2,3 & 0,1 & 88,5 & 0,2 & 0,9 & 1,5 & 4,6 & 2,4 \\
\hline $\begin{array}{l}\text { Wetenschappelijke } \\
\text { beroepen (techniek etc) }\end{array}$ & 0,4 & 0,0 & 1,1 & 1,1 & 0,4 & 1,1 & 0,0 & 87,9 & 0,4 & 3,2 & 4,6 & 0,3 \\
\hline $\begin{array}{l}\text { Wetenschappelijke } \\
\text { economische adm. } \\
\text { beroepen e.d. }\end{array}$ & 0,0 & 0,0 & 1,0 & 0,0 & 1,2 & 0,0 & 1,7 & 0,5 & 90,3 & 1,2 & 4,1 & 0,4 \\
\hline Werkloosheid & 6,9 & 5,5 & 9,7 & 3,0 & 5,7 & 1,8 & 1,5 & 0,3 & 0,3 & 27,0 & 38,3 & 6,4 \\
\hline Non-participatie & 2,0 & 1,1 & 2,5 & 0,5 & 1,0 & 0,3 & 0,2 & 0,1 & 0,0 & 3,9 & 88,3 & 89,1 \\
\hline
\end{tabular}


Tabel 18: Beroep en arbeidsmarktpositie tussen kwartalen $t$ en $t+1$ van 25-34 jarigen (1 digit), 2002-2005 (ongewogen)

\begin{tabular}{|c|c|c|c|c|c|c|c|c|c|c|c|c|}
\hline$n^{\mathrm{t}+1}$ & $\begin{array}{l}\text { Elementaire } \\
\text { beroepen }\end{array}$ & $\begin{array}{c}\text { Lagere } \\
\text { Beroepen } \\
\text { (techniek } \\
\text { etc) }\end{array}$ & $\begin{array}{l}\text { Lagere adm., } \\
\text { commerciële } \\
\text { beroepen } \\
\text { e.d. }\end{array}$ & $\begin{array}{l}\text { Middelbare } \\
\text { beroepen } \\
\text { (techniek } \\
\text { etc) }\end{array}$ & $\begin{array}{l}\text { Middelbare } \\
\text { adm., } \\
\text { commerciële } \\
\text { beroepen } \\
\text { e.d. }\end{array}$ & $\begin{array}{c}\text { Hogere } \\
\text { beroepen } \\
\text { (techniek } \\
\text { etc) }\end{array}$ & $\begin{array}{l}\text { Hogere } \\
\text { adm., } \\
\text { commerciële } \\
\text { beroepen } \\
\text { e.d. }\end{array}$ & $\begin{array}{l}\text { Wetenschap- } \\
\text { pelijke } \\
\text { beroepen } \\
\text { (techniek } \\
\text { etc) }\end{array}$ & $\begin{array}{l}\text { Wetenschap- } \\
\text { pelijke } \\
\text { economische } \\
\text { adm. } \\
\text { beroepen } \\
\text { e.d. }\end{array}$ & $\begin{array}{l}\text { Werkloos- } \\
\text { heid }\end{array}$ & $\begin{array}{c}\text { Non- } \\
\text { participatie }\end{array}$ & $\begin{array}{c}\mathrm{N} \\
(\mathrm{x} 1000)\end{array}$ \\
\hline Elementaire beroepen & 91,1 & 1,0 & 0,9 & 0,7 & 1,0 & 0,1 & 0,2 & 0,0 & 0,0 & 2,0 & 3,0 & 8,0 \\
\hline $\begin{array}{l}\text { Lagere Beroepen (techniek } \\
\text { etc) }\end{array}$ & 0,5 & 95,7 & 0,2 & 0,8 & 0,4 & 0,1 & 0,1 & 0,0 & 0,0 & 1,2 & 1,0 & 17,0 \\
\hline $\begin{array}{l}\text { Lagere adm., commerciele } \\
\text { beroepen e.d. }\end{array}$ & 0,4 & 0,2 & 93,6 & 0,3 & 1,6 & 0,1 & 0,3 & 0,1 & 0,1 & 1,4 & 1,9 & 15,7 \\
\hline $\begin{array}{l}\text { Middelbare beroepen } \\
\text { (techniek etc) }\end{array}$ & 0,1 & 0,3 & 0,1 & 97,2 & 0,4 & 0,3 & 0,2 & 0,1 & 0,1 & 0,5 & 0,7 & 29,3 \\
\hline $\begin{array}{l}\text { Middelbare adm, } \\
\text { commerciele beroepen e.d. }\end{array}$ & 0,1 & 0,1 & 0,4 & 0,3 & 96,1 & 0,2 & 0,9 & 0,0 & 0,1 & 0,8 & 0,9 & 42,0 \\
\hline $\begin{array}{l}\text { Hogere beroepen (techniek } \\
\text { etc) }\end{array}$ & 0,0 & 0,0 & 0,1 & 0,4 & 0,4 & 97,2 & 0,5 & 0,3 & 0,1 & 0,4 & 0,7 & 15,6 \\
\hline $\begin{array}{l}\text { Hogere adm, commerciele } \\
\text { beroepen e.d. }\end{array}$ & 0,0 & 0,1 & 0,2 & 0,3 & 1,2 & 0,3 & 96,0 & 0,1 & 0,5 & 0,8 & 0,6 & 23,3 \\
\hline $\begin{array}{l}\text { Wetenschappelijke } \\
\text { beroepen (techniek etc) }\end{array}$ & 0,0 & 0,0 & 0,1 & 0,4 & 0,2 & 0,4 & 0,6 & 96,1 & 0,3 & 1,0 & 0,8 & 5,9 \\
\hline $\begin{array}{l}\text { Wetenschappelijke } \\
\text { economische adm. } \\
\text { beroepen e.d. }\end{array}$ & 0,0 & 0,0 & 0,1 & 0,1 & 0,7 & 0,2 & 1,4 & 0,2 & 96,0 & 0,7 & 0,6 & 7,9 \\
\hline Werkloosheid & 3,6 & 4,2 & 5,1 & 2,8 & 7,9 & 1,8 & 3,4 & 1,5 & 1,2 & 45,9 & 22,5 & 6,2 \\
\hline Non-participatie & 0,8 & 0,5 & 0,9 & 0,5 & 1,2 & 0,4 & 0,5 & 0,2 & 0,1 & 6,8 & 88,0 & 26,2 \\
\hline
\end{tabular}


Tabel 19: Beroep en arbeidsmarktpositie tussen kwartalen $t$ en $t+1$ van 35-44 jarigen (1 digit), 2002-2005 (ongewogen)

\begin{tabular}{|c|c|c|c|c|c|c|c|c|c|c|c|c|}
\hline$n^{t+1}$ & $\begin{array}{c}\text { Elementaire } \\
\text { beroepen }\end{array}$ & $\begin{array}{c}\text { Lagere } \\
\text { Beroepen } \\
\text { (techniek } \\
\text { etc) }\end{array}$ & $\begin{array}{c}\text { Lagere adm., } \\
\text { commerciële } \\
\text { beroepen } \\
\text { e.d. }\end{array}$ & $\begin{array}{l}\text { Middelbare } \\
\text { beroepen } \\
\text { (techniek } \\
\text { etc) }\end{array}$ & $\begin{array}{l}\text { Middelbare } \\
\text { adm., } \\
\text { commerciële } \\
\text { beroepen } \\
\text { e.d. }\end{array}$ & $\begin{array}{l}\text { Hogere } \\
\text { beroepen } \\
\text { (techniek } \\
\text { etc) }\end{array}$ & $\begin{array}{c}\text { Hogere } \\
\text { adm., } \\
\text { commerciële } \\
\text { beroepen } \\
\text { e.d. }\end{array}$ & $\begin{array}{l}\text { Wetenschap- } \\
\text { pelijke } \\
\text { beroepen } \\
\text { (techniek } \\
\text { etc) }\end{array}$ & $\begin{array}{l}\text { Wetenschap- } \\
\text { pelijke } \\
\text { economische } \\
\text { adm. } \\
\text { beroepen } \\
\text { e.d. }\end{array}$ & 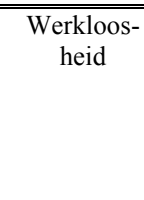 & $\begin{array}{c}\text { Non- } \\
\text { participatie }\end{array}$ & $\begin{array}{c}\mathrm{N} \\
(\mathrm{x} 1000)\end{array}$ \\
\hline Elementaire beroepen & 94,0 & 0,6 & 0,6 & 0,5 & 0,4 & 0,1 & 0,1 & 0,0 & 0,0 & 1,6 & 2,2 & 11,4 \\
\hline $\begin{array}{l}\text { Lagere Beroepen (techniek } \\
\text { etc) }\end{array}$ & 0,3 & 97,2 & 0,1 & 0,5 & 0,2 & 0,1 & 0,1 & 0,0 & 0,0 & 0,7 & 0,8 & 24,1 \\
\hline $\begin{array}{l}\text { Lagere adm., commerciele } \\
\text { beroepen e.d. }\end{array}$ & 0,2 & 0,1 & 95,7 & 0,2 & 1,0 & 0,1 & 0,1 & 0,0 & 0,0 & 0,9 & 1,6 & 20,1 \\
\hline $\begin{array}{l}\text { Middelbare beroepen } \\
\text { (techniek etc) }\end{array}$ & 0,1 & 0,2 & 0,1 & 97,9 & 0,3 & 0,2 & 0,2 & 0,0 & 0,1 & 0,4 & 0,5 & 41,0 \\
\hline $\begin{array}{l}\text { Middelbare adm, } \\
\text { commerciele beroepen e.d. }\end{array}$ & 0,1 & 0,1 & 0,3 & 0,2 & 97,1 & 0,1 & 0,6 & 0,0 & 0,1 & 0,6 & 0,7 & 52,3 \\
\hline $\begin{array}{l}\text { Hogere beroepen (techniek } \\
\text { etc) }\end{array}$ & 0,0 & 0,0 & 0,1 & 0,3 & 0,2 & 97,5 & 0,5 & 0,2 & 0,1 & 0,3 & 0,8 & 20,8 \\
\hline $\begin{array}{l}\text { Hogere adm, commerciele } \\
\text { beroepen e.d. }\end{array}$ & 0,0 & 0,1 & 0,1 & 0,2 & 0,7 & 0,3 & 97,0 & 0,1 & 0,5 & 0,6 & 0,5 & 32,5 \\
\hline $\begin{array}{l}\text { Wetenschappelijke } \\
\text { beroepen (techniek etc) }\end{array}$ & 0,0 & 0,0 & 0,0 & 0,2 & 0,2 & 0,4 & 0,4 & 97,2 & 0,6 & 0,5 & 0,5 & 8,1 \\
\hline $\begin{array}{l}\text { Wetenschappelijke } \\
\text { economische adm. } \\
\text { beroepen e.d. }\end{array}$ & 0,0 & 0,0 & 0,1 & 0,1 & 0,3 & 0,2 & 1,1 & 0,3 & 97,3 & 0,4 & 0,3 & 12,2 \\
\hline Werkloosheid & 2,5 & 2,8 & 3,7 & 2,4 & 5,0 & 1,2 & 2,2 & 0,5 & 0,9 & 52,1 & 26,6 & 8,3 \\
\hline Non-participatie & 0,5 & 0,4 & 0,6 & 0,4 & 0,8 & 0,4 & 0,3 & 0,1 & 0,1 & 5,6 & 90,8 & $\overline{44,5}$ \\
\hline
\end{tabular}


Tabel 20: Beroep en arbeidsmarktpositie tussen kwartalen $t$ en $t+1$ van 45-54 jarigen (1 digit), 2002-2005 (ongewogen)

\begin{tabular}{|c|c|c|c|c|c|c|c|c|c|c|c|c|}
\hline$n^{t+1}$ & $\begin{array}{c}\text { Elementaire } \\
\text { beroepen }\end{array}$ & $\begin{array}{c}\text { Lagere } \\
\text { Beroepen } \\
\text { (techniek } \\
\text { etc) }\end{array}$ & $\begin{array}{c}\text { Lagere adm., } \\
\text { commerciële } \\
\text { beroepen } \\
\text { e.d. }\end{array}$ & $\begin{array}{c}\text { Middelbare } \\
\text { beroepen } \\
\text { (techniek } \\
\text { etc) }\end{array}$ & $\begin{array}{l}\text { Middelbare } \\
\text { adm., } \\
\text { commerciële } \\
\text { beroepen } \\
\text { e.d. }\end{array}$ & $\begin{array}{c}\text { Hogere } \\
\text { beroepen } \\
\text { (techniek } \\
\text { etc) }\end{array}$ & $\begin{array}{c}\text { Hogere } \\
\text { adm., } \\
\text { commerciële } \\
\text { beroepen } \\
\text { e.d. }\end{array}$ & $\begin{array}{l}\text { Wetenschap- } \\
\text { pelijke } \\
\text { beroepen } \\
\text { (techniek } \\
\text { etc) }\end{array}$ & $\begin{array}{c}\text { Wetenschap- } \\
\text { pelijke } \\
\text { economische } \\
\text { adm. } \\
\text { beroepen } \\
\text { e.d. }\end{array}$ & $\begin{array}{l}\begin{array}{l}\text { Werkloos- } \\
\text { heid }\end{array} \\
\text { heid }\end{array}$ & $\begin{array}{c}\text { Non- } \\
\text { participatie }\end{array}$ & $\begin{array}{c}\mathrm{N} \\
(\mathrm{x} \\
1000)\end{array}$ \\
\hline Elementaire beroepen & 95,2 & 0,4 & 0,5 & 0,2 & 0,2 & 0,0 & 0,1 & 0,0 & 0,0 & 1,1 & 2,4 & 10,3 \\
\hline $\begin{array}{l}\text { Lagere Beroepen (techniek } \\
\text { etc) }\end{array}$ & 0,2 & 97,5 & 0,1 & 0,3 & 0,2 & 0,0 & 0,0 & 0,0 & 0,0 & 0,7 & 0,9 & 21,2 \\
\hline $\begin{array}{l}\text { Lagere adm., commerciele } \\
\text { beroepen e.d. }\end{array}$ & 0,2 & 0,1 & 96,5 & 0,1 & 0,6 & 0,1 & 0,1 & 0,0 & 0,0 & 0,8 & 1,5 & 18,9 \\
\hline $\begin{array}{l}\text { Middelbare beroepen } \\
\text { (techniek etc) }\end{array}$ & 0,1 & 0,2 & 0,1 & 98,2 & 0,2 & 0,2 & 0,1 & 0,0 & 0,1 & 0,4 & 0,5 & 34,2 \\
\hline $\begin{array}{l}\text { Middelbare adm, } \\
\text { commerciele beroepen e.d. }\end{array}$ & 0,0 & 0,1 & 0,3 & 0,2 & 97,5 & 0,1 & 0,3 & 0,0 & 0,1 & 0,6 & 0,8 & 38,3 \\
\hline $\begin{array}{l}\text { Hogere beroepen (techniek } \\
\text { etc) }\end{array}$ & 0,0 & 0,0 & 0,0 & 0,2 & 0,2 & 98,0 & 0,4 & 0,1 & 0,2 & 0,3 & 0,6 & 22,6 \\
\hline $\begin{array}{l}\text { Hogere adm, commerciele } \\
\text { beroepen e.d. }\end{array}$ & 0,0 & 0,0 & 0,1 & 0,1 & 0,5 & 0,3 & 97,6 & 0,1 & 0,4 & 0,5 & 0,5 & 24,6 \\
\hline $\begin{array}{l}\text { Wetenschappelijke } \\
\text { beroepen (techniek etc) }\end{array}$ & 0,0 & 0,0 & 0,0 & 0,1 & 0,1 & 0,2 & 0,4 & 98,1 & 0,4 & 0,3 & 0,4 & 7,9 \\
\hline $\begin{array}{l}\text { Wetenschappelijke } \\
\text { economische adm. } \\
\text { beroepen e.d. }\end{array}$ & 0,0 & 0,0 & 0,0 & 0,1 & 0,2 & 0,2 & 0,8 & 0,3 & 97,8 & 0,3 & 0,3 & 10,6 \\
\hline Werkloosheid & 1,9 & 2,6 & 2,9 & 1,7 & 3,0 & 1,0 & 1,2 & 0,3 & 0,5 & 57,6 & 27,2 & 6,7 \\
\hline Non-participatie & 0,3 & 0,3 & 0,5 & 0,3 & 0,4 & 0,2 & 0,2 & 0,1 & 0,0 & 3,7 & 93,9 & 48,7 \\
\hline
\end{tabular}


Tabel 21: Beroep en arbeidsmarktpositie tussen kwartalen $t$ en $t+1$ van 55-64 jarigen (1 digit), 2002-2005 (ongewogen)

\begin{tabular}{|c|c|c|c|c|c|c|c|c|c|c|c|c|}
\hline$n^{t+1}$ & $\begin{array}{c}\text { Elementaire } \\
\text { beroepen }\end{array}$ & $\begin{array}{c}\text { Lagere } \\
\text { Beroepen } \\
\text { (techniek } \\
\text { etc) }\end{array}$ & $\begin{array}{c}\text { Lagere adm., } \\
\text { commerciële } \\
\text { beroepen } \\
\text { e.d. }\end{array}$ & $\begin{array}{c}\text { Middelbare } \\
\text { beroepen } \\
\text { (techniek } \\
\text { etc) }\end{array}$ & $\begin{array}{l}\text { Middelbare } \\
\text { adm., } \\
\text { commerciële } \\
\text { beroepen } \\
\text { e.d. }\end{array}$ & $\begin{array}{c}\text { Hogere } \\
\text { beroepen } \\
\text { (techniek } \\
\text { etc) }\end{array}$ & $\begin{array}{l}\text { Hogere } \\
\text { adm., } \\
\text { commerciële } \\
\text { beroepen } \\
\text { e.d. }\end{array}$ & $\begin{array}{l}\text { Wetenschap- } \\
\text { pelijke } \\
\text { beroepen } \\
\text { (techniek } \\
\text { etc) }\end{array}$ & $\begin{array}{l}\text { Wetenschap- } \\
\text { pelijke } \\
\text { economische } \\
\text { adm. } \\
\text { beroepen } \\
\text { e.d. }\end{array}$ & $\begin{array}{l}\text { Werkloos- } \\
\text { heid }\end{array}$ & $\begin{array}{c}\text { Non- } \\
\text { participatie }\end{array}$ & $\begin{array}{c}\mathrm{N} \\
(\mathrm{x} 1000)\end{array}$ \\
\hline Elementaire beroepen & 94,0 & 0,2 & 0,2 & 0,1 & 0,2 & 0,0 & 0,0 & 0,0 & 0,0 & 0,7 & 4,6 & 4,7 \\
\hline $\begin{array}{l}\text { Lagere Beroepen (techniek } \\
\text { etc) }\end{array}$ & 0,1 & 95,2 & 0,1 & 0,2 & 0,1 & 0,0 & 0,0 & 0,0 & 0,0 & 0,5 & 3,9 & 10,3 \\
\hline $\begin{array}{l}\text { Lagere adm., commerciele } \\
\text { beroepen e.d. }\end{array}$ & 0,2 & 0,1 & 95,0 & 0,0 & 0,3 & 0,0 & 0,0 & 0,0 & 0,0 & 0,4 & 3,9 & 7,9 \\
\hline $\begin{array}{l}\text { Middelbare beroepen } \\
\text { (techniek etc) }\end{array}$ & 0,1 & 0,1 & 0,0 & 95,9 & 0,2 & 0,1 & 0,1 & 0,0 & 0,0 & 0,3 & 3,3 & 14,4 \\
\hline $\begin{array}{l}\text { Middelbare adm, } \\
\text { commerciele beroepen e.d. }\end{array}$ & 0,0 & 0,1 & 0,1 & 0,1 & 95,2 & 0,0 & 0,2 & 0,0 & 0,1 & 0,4 & 3,7 & 14,7 \\
\hline $\begin{array}{l}\text { Hogere beroepen (techniek } \\
\text { etc) }\end{array}$ & 0,0 & 0,0 & 0,1 & 0,1 & 0,1 & 95,7 & 0,2 & 0,0 & 0,1 & 0,2 & 3,5 & 9,4 \\
\hline $\begin{array}{l}\text { Hogere adm, commerciele } \\
\text { beroepen e.d. }\end{array}$ & 0,0 & 0,1 & 0,0 & 0,1 & 0,3 & 0,2 & 95,6 & 0,1 & 0,1 & 0,4 & 3,2 & 10,1 \\
\hline $\begin{array}{l}\text { Wetenschappelijke } \\
\text { beroepen (techniek etc) }\end{array}$ & 0,0 & 0,0 & 0,0 & 0,0 & 0,0 & 0,2 & 0,3 & 95,7 & 0,2 & 0,4 & 3,2 & 4,1 \\
\hline $\begin{array}{l}\text { Wetenschappelijke } \\
\text { economische adm. } \\
\text { beroepen e.d. }\end{array}$ & 0,0 & 0,0 & 0,1 & 0,0 & 0,1 & 0,1 & 0,5 & 0,2 & 94,8 & 0,3 & 3,8 & 4,8 \\
\hline Werkloosheid & 0,9 & 1,9 & 1,1 & 1,2 & 1,3 & 0,6 & 1,1 & 0,5 & 0,3 & 57,0 & 34,0 & 3,0 \\
\hline Non-participatie & 0,1 & 0,1 & 0,1 & 0,1 & 0,1 & 0,1 & 0,1 & 0,0 & 0,0 & 0,7 & 98,5 & 101,1 \\
\hline
\end{tabular}


Uit tabel 18 blijkt dat de beroepenmobiliteit van 25-34 jarigen nauwelijks afwijkt van de totale beroepenmobiliteit. Het meest opvallende is dat de mobiliteit richting nonparticipatie lager is dan voor de 15-24 jarigen. Tabellen 19 en 20 laten zien dat de mobiliteit nog verder afneemt met de leeftijd. De mobiliteit richting non-participatie is voor 35-44 jarigen en 45-54 jarigen het laagst. Desondanks, het percentage werkenden dat duurzaam non-participant is neemt toe met de leeftijd. Voor de 55-64 jarigen (tabel 21) geldt dat de mobiliteit groter is dan voor de 35-44 jarigen en jarigen, hoewel de mobiliteit lager is dan voor de 15-24 jarigen. De mobiliteit richting werkloosheid is lager voor de oudste leeftijdsgroep. De meeste mensen zijn mobiel richting non-participatie. Het betreft hier mensen die (vervroegd) met pensioen gaan. Dat deze uittrede van de arbeidsmarkt doorgaans definitief is, blijkt ook uit het hoge percentage non-participanten dat non-participant blijft (98,5\%).

Als laatste is gekeken naar de mobiliteit van alleenstaanden, samenwonenden en samenwonenden met kinderen. Verwacht kan worden dat alleenstaanden mobieler zijn. Doorgaans zal de groep alleenstaanden vooral uit jongeren bestaan en hoeven alleenstaanden niet de verantwoordelijkheid te dragen voor overige leden in hun huishouden. Alleenstaanden hoeven doorgaans bij de keuze om van beroep te wisselen dus minder rekening te houden met de consequenties voor familieleden. Tevens kan worden verwacht dat samenwonenden met kinderen meer baan- en inkomenszekerheid wensen en ook minder bereid zijn om van beroep te wisselen. De Tabellen 22 tot en met 24 tonen de mobiliteit van de verschillende groepen. Volgens de verwachting is de baanmobiliteit onder alleenstaanden groter. De baanmobiliteit onder samenwonenden is groter dan onder samenwonenden met kinderen. Opvallend is dat alleenstaanden vaker werkloos blijven. Samenwonenden blijven vaker nonparticipant, terwijl onder samenwonenden met kinderen vooral veel werklozen uitstromen richting non-participatie.

\subsection{Beroepenmobiliteit volgens de internationale definitie van werkloosheid}

De plausibiliteit van de mobiliteitstromen kan verder worden onderzocht door de internationale definitie van werkloosheid toe te passen. Zoals reeds eerder vermeld worden personen volgens de CBS-definitie als werkloos beschouwd als zij tussen de leeftijd van 15 en 64 jaar zijn en niet of minder dan 12 uur per week werken en beschikbaar zijn en actief op zoek zijn naar een baan van 12 uur per week of meer. In de internationale definitie (ILO-definitie) is deze grens op 1 uur per week gesteld. De verwachting is dat bij hantering van de internationale definitie de uitstroom naar werkloosheid en non-participatie kleiner is. Vooral voor jongeren met bijbanen naast de studie kan worden verwacht dat de mobiliteit lager zal zijn. In tabel 25 wordt de beroepenmobiliteit weergegeven als de internationale definitie van werkloosheid wordt gehanteerd. De tabel laat zien dat de beroepenmobiliteit inderdaad kleiner is bij de 1-uursgrens dan bij hantering van de CBS-definitie van werkloosheid. De uitstroom naar werkloosheid en non-participatie is op alle beroepsniveaus lager, vooral voor mensen die werkzaam zijn in de elementaire en lagere administratieve, commerciële en economische beroepen. 
Tabel 22: Beroep en arbeidsmarktpositie tussen kwartalen $t$ en $t+1$ van alleenstaanden (1 digit), 2002-2005 (ongewogen)

\begin{tabular}{|c|c|c|c|c|c|c|c|c|c|c|c|c|}
\hline$n^{t+1}$ & $\begin{array}{c}\text { Elementaire } \\
\text { beroepen }\end{array}$ & $\begin{array}{c}\text { Lagere } \\
\text { Beroepen } \\
\text { (techniek } \\
\text { etc) }\end{array}$ & $\begin{array}{c}\text { Lagere adm., } \\
\text { commerciële } \\
\text { beroepen } \\
\text { e.d. }\end{array}$ & $\begin{array}{c}\text { Middelbare } \\
\text { beroepen } \\
\text { (techniek } \\
\text { etc) }\end{array}$ & $\begin{array}{l}\text { Middelbare } \\
\text { adm., } \\
\text { commerciële } \\
\text { beroepen } \\
\text { e.d. }\end{array}$ & $\begin{array}{c}\text { Hogere } \\
\text { beroepen } \\
\text { (techniek } \\
\text { etc) }\end{array}$ & $\begin{array}{l}\text { Hogere } \\
\text { adm., } \\
\text { commerciële } \\
\text { beroepen } \\
\text { e.d. }\end{array}$ & $\begin{array}{l}\text { Wetenschap- } \\
\text { pelijke } \\
\text { beroepen } \\
\text { (techniek } \\
\text { etc) }\end{array}$ & $\begin{array}{l}\text { Wetenschap- } \\
\text { pelijke } \\
\text { economische } \\
\text { adm. } \\
\text { beroepen } \\
\text { e.d. }\end{array}$ & $\begin{array}{l}\text { Werkloos- } \\
\text { heid }\end{array}$ & $\begin{array}{c}\text { Non- } \\
\text { participatie }\end{array}$ & $\begin{array}{c}\mathrm{N} \\
(\mathrm{x} 1000)\end{array}$ \\
\hline Elementaire beroepen & 91,4 & 0,8 & 0,5 & 0,4 & 0,9 & 0,2 & 0,2 & 0,0 & 0,0 & 2,5 & 3,1 & 4,3 \\
\hline $\begin{array}{l}\text { Lagere Beroepen (techniek } \\
\text { etc) }\end{array}$ & 0,5 & 94,5 & 0,3 & 0,6 & 0,3 & 0,1 & 0,1 & 0,0 & 0,0 & 1,5 & 2,0 & 6,7 \\
\hline $\begin{array}{l}\text { Lagere adm., commerciele } \\
\text { beroepen e.d. }\end{array}$ & 0,5 & 0,3 & 92,1 & 0,2 & 1,5 & 0,2 & 0,4 & 0,0 & 0,1 & 1,5 & 3,2 & 6,3 \\
\hline $\begin{array}{l}\text { Middelbare beroepen } \\
\text { (techniek etc) }\end{array}$ & 0,2 & 0,2 & 0,1 & 96,4 & 0,4 & 0,2 & 0,2 & 0,1 & 0,1 & 0,9 & 1,2 & 9,6 \\
\hline $\begin{array}{l}\text { Middelbare adm, } \\
\text { commerciele beroepen e.d. }\end{array}$ & 0,1 & 0,1 & 0,5 & 0,2 & 95,4 & 0,1 & 0,8 & 0,1 & 0,2 & 1,1 & 1,4 & 15,0 \\
\hline $\begin{array}{l}\text { Hogere beroepen (techniek } \\
\text { etc) }\end{array}$ & 0,0 & 0,0 & 0,1 & 0,3 & 0,4 & 96,2 & 0,4 & 0,3 & 0,1 & 0,6 & 1,4 & 6,6 \\
\hline $\begin{array}{l}\text { Hogere adm, commerciele } \\
\text { beroepen e.d. }\end{array}$ & 0,0 & 0,1 & 0,1 & 0,2 & 1,1 & 0,3 & 95,5 & 0,1 & 0,4 & 1,0 & 1,0 & 10,2 \\
\hline $\begin{array}{l}\text { Wetenschappelijke } \\
\text { beroepen (techniek etc) }\end{array}$ & 0,1 & 0,1 & 0,1 & 0,3 & 0,1 & 0,3 & 0,5 & 95,6 & 0,3 & 1,3 & 1,2 & 2,9 \\
\hline $\begin{array}{l}\text { Wetenschappelijke } \\
\text { economische adm. } \\
\text { beroepen e.d. }\end{array}$ & 0,0 & 0,0 & 0,1 & 0,1 & 0,3 & 0,1 & 1,0 & 0,2 & 96,1 & 1,0 & 1,1 & 3,8 \\
\hline Werkloosheid & 2,7 & 2,8 & 3,5 & 1,9 & 4,5 & 1,2 & 2,9 & 0,9 & 0,9 & 56,1 & 22,6 & 4,5 \\
\hline Non-participatie & 0,4 & 0,4 & 0,8 & 0,3 & 0,8 & 0,3 & 0,4 & 0,2 & 0,1 & 4,0 & 92,4 & 26,4 \\
\hline
\end{tabular}


Tabel 23: Beroep en arbeidsmarktpositie tussen kwartalen $t$ en $t+1$ van samenwonenden (1 digit), 2002-2005 (ongewogen)

\begin{tabular}{|c|c|c|c|c|c|c|c|c|c|c|c|c|}
\hline$n^{t+1}$ & $\begin{array}{c}\text { Elementaire } \\
\text { beroepen }\end{array}$ & $\begin{array}{c}\text { Lagere } \\
\text { Beroepen } \\
\text { (techniek } \\
\text { etc) }\end{array}$ & $\begin{array}{l}\text { Lagere adm., } \\
\text { commerciële } \\
\text { beroepen } \\
\text { e.d. }\end{array}$ & $\begin{array}{l}\text { Middelbare } \\
\text { beroepen } \\
\text { (techniek } \\
\text { etc) }\end{array}$ & $\begin{array}{l}\text { Middelbare } \\
\text { adm., } \\
\text { commerciële } \\
\text { beroepen } \\
\text { e.d. }\end{array}$ & $\begin{array}{c}\text { Hogere } \\
\text { beroepen } \\
\text { (techniek } \\
\text { etc) }\end{array}$ & $\begin{array}{l}\text { Hogere } \\
\text { adm., } \\
\text { commerciële } \\
\text { beroepen } \\
\text { e.d. }\end{array}$ & $\begin{array}{l}\text { Wetenschap- } \\
\text { pelijke } \\
\text { beroepen } \\
\text { (techniek } \\
\text { etc) }\end{array}$ & $\begin{array}{l}\text { Wetenschap- } \\
\text { pelijke } \\
\text { economische } \\
\text { adm. } \\
\text { beroepen } \\
\text { e.d. }\end{array}$ & $\begin{array}{l}\text { Werkloos- } \\
\text { heid }\end{array}$ & $\begin{array}{c}\text { Non- } \\
\text { participatie }\end{array}$ & $\begin{array}{c}\mathrm{N} \\
(\mathrm{x} 1000)\end{array}$ \\
\hline Elementaire beroepen & 93,6 & 0,6 & 0,5 & 0,4 & 0,4 & 0,1 & 0,2 & 0,0 & 0,0 & 1,0 & 3,2 & 2,3 \\
\hline $\begin{array}{l}\text { Lagere Beroepen (techniek } \\
\text { etc) }\end{array}$ & 0,3 & 95,7 & 0,2 & 0,5 & 0,3 & 0,1 & 0,1 & 0,0 & 0,0 & 0,8 & 2,2 & 4,8 \\
\hline $\begin{array}{l}\text { Lagere adm., commerciele } \\
\text { beroepen e.d. }\end{array}$ & 0,2 & 0,2 & 95,0 & 0,2 & 1,1 & 0,1 & 0,2 & 0,0 & 0,1 & 0,8 & 2,1 & 4,8 \\
\hline $\begin{array}{l}\text { Middelbare beroepen } \\
\text { (techniek etc) }\end{array}$ & 0,1 & 0,2 & 0,1 & 96,8 & 0,4 & 0,2 & 0,2 & 0,0 & 0,1 & 0,4 & 1,5 & 7,6 \\
\hline $\begin{array}{l}\text { Middelbare adm, } \\
\text { commerciele beroepen e.d. }\end{array}$ & 0,1 & 0,1 & 0,4 & 0,2 & 96,1 & 0,1 & 0,6 & 0,0 & 0,1 & 0,7 & 1,6 & 10,5 \\
\hline $\begin{array}{l}\text { Hogere beroepen (techniek } \\
\text { etc) }\end{array}$ & 0,0 & 0,0 & 0,1 & 0,3 & 0,2 & 97,0 & 0,4 & 0,2 & 0,1 & 0,3 & 1,5 & 4,8 \\
\hline $\begin{array}{l}\text { Hogere adm, commerciele } \\
\text { beroepen e.d. }\end{array}$ & 0,0 & 0,0 & 0,1 & 0,2 & 0,9 & 0,3 & 96,1 & 0,1 & 0,4 & 0,6 & 1,3 & 6,5 \\
\hline $\begin{array}{l}\text { Wetenschappelijke } \\
\text { beroepen (techniek etc) }\end{array}$ & 0,0 & 0,0 & 0,0 & 0,2 & 0,2 & 0,4 & 0,5 & 96,0 & 0,3 & 0,7 & 1,7 & 1,9 \\
\hline $\begin{array}{l}\text { Wetenschappelijke } \\
\text { economische adm. } \\
\text { beroepen e.d. }\end{array}$ & 0,0 & 0,0 & 0,1 & 0,1 & 0,5 & 0,2 & 1,1 & 0,3 & 95,8 & 0,5 & 1,5 & 2,6 \\
\hline Werkloosheid & 2,2 & 3,3 & 4,0 & 2,3 & 5,7 & 1,8 & 2,5 & 1,0 & 1,3 & 50,5 & 25,2 & 1,3 \\
\hline Non-participatie & 0,2 & 0,2 & 0,2 & 0,2 & 0,3 & 0,1 & 0,1 & 0,1 & 0,1 & 1,3 & 97,4 & 27,6 \\
\hline
\end{tabular}


Tabel 24: Beroep en arbeidsmarktpositie tussen kwartalen $t$ en $t+1$ van samenwonenden met kinderen (1 digit), 2002-2005 (ongewogen)

\begin{tabular}{|c|c|c|c|c|c|c|c|c|c|c|c|c|}
\hline$n^{t+1}$ & $\begin{array}{c}\text { Elementaire } \\
\text { beroepen }\end{array}$ & $\begin{array}{c}\text { Lagere } \\
\text { Beroepen } \\
\text { (techniek } \\
\text { etc) }\end{array}$ & $\begin{array}{l}\text { Lagere adm., } \\
\text { commerciële } \\
\text { beroepen } \\
\text { e.d. }\end{array}$ & $\begin{array}{c}\text { Middelbare } \\
\text { beroepen } \\
\text { (techniek } \\
\text { etc) }\end{array}$ & $\begin{array}{l}\text { Middelbare } \\
\text { adm., } \\
\text { commerciële } \\
\text { beroepen } \\
\text { e.d. }\end{array}$ & $\begin{array}{c}\text { Hogere } \\
\text { beroepen } \\
\text { (techniek } \\
\text { etc) }\end{array}$ & $\begin{array}{l}\text { Hogere } \\
\text { adm., } \\
\text { commerciële } \\
\text { beroepen } \\
\text { e.d. }\end{array}$ & $\begin{array}{l}\text { Wetenschap- } \\
\text { pelijke } \\
\text { beroepen } \\
\text { (techniek } \\
\text { etc) }\end{array}$ & $\begin{array}{c}\text { Wetenschap- } \\
\text { pelijke } \\
\text { economische } \\
\text { adm. } \\
\text { beroepen } \\
\text { e.d. }\end{array}$ & $\begin{array}{l}\text { Werkloos- } \\
\text { heid }\end{array}$ & $\begin{array}{c}\text { Non- } \\
\text { participatie }\end{array}$ & $\begin{array}{c}\mathrm{N} \\
(\mathrm{x} 1000)\end{array}$ \\
\hline Elementaire beroepen & 94,2 & 0,6 & 0,6 & 0,4 & 0,4 & 0,0 & 0,1 & 0,0 & 0,0 & 1,4 & 2,4 & 17,6 \\
\hline $\begin{array}{l}\text { Lagere Beroepen (techniek } \\
\text { etc) }\end{array}$ & 0,2 & 97,3 & 0,1 & 0,5 & 0,2 & 0,1 & 0,1 & 0,0 & 0,0 & 0,7 & 0,8 & 41,6 \\
\hline $\begin{array}{l}\text { Lagere adm., commerciele } \\
\text { beroepen e.d. }\end{array}$ & 0,2 & 0,1 & 95,8 & 0,2 & 0,9 & 0,0 & 0,1 & 0,0 & 0,0 & 0,9 & 1,7 & 33,2 \\
\hline $\begin{array}{l}\text { Middelbare beroepen } \\
\text { (techniek etc) }\end{array}$ & 0,1 & 0,2 & 0,1 & 98,0 & 0,3 & 0,2 & 0,2 & 0,0 & 0,1 & 0,3 & 0,6 & 71,2 \\
\hline $\begin{array}{l}\text { Middelbare adm, } \\
\text { commerciele beroepen e.d. }\end{array}$ & 0,1 & 0,1 & 0,3 & 0,2 & 97,1 & 0,1 & 0,6 & 0,0 & 0,1 & 0,6 & 0,8 & 80,8 \\
\hline $\begin{array}{l}\text { Hogere beroepen (techniek } \\
\text { etc) }\end{array}$ & 0,0 & 0,0 & 0,0 & 0,2 & 0,2 & 97,6 & 0,4 & 0,2 & 0,2 & 0,3 & 0,8 & 38,7 \\
\hline $\begin{array}{l}\text { Hogere adm, commerciele } \\
\text { beroepen e.d. }\end{array}$ & 0,0 & 0,1 & 0,1 & 0,2 & 0,6 & 0,3 & 97,2 & 0,1 & 0,5 & 0,4 & 0,6 & 48,6 \\
\hline $\begin{array}{l}\text { Wetenschappelijke } \\
\text { beroepen (techniek etc) }\end{array}$ & 0,0 & 0,0 & 0,0 & 0,2 & 0,1 & 0,3 & 0,4 & 97,6 & 0,5 & 0,4 & 0,6 & 14,0 \\
\hline $\begin{array}{l}\text { Wetenschappelijke } \\
\text { economische adm. } \\
\text { beroepen e.d. }\end{array}$ & 0,0 & 0,0 & 0,1 & 0,1 & 0,3 & 0,2 & 1,0 & 0,2 & 97,3 & 0,3 & 0,5 & 19,2 \\
\hline Werkloosheid & 2,5 & 3,0 & 3,7 & 2,4 & 4,7 & 1,2 & 1,7 & 0,5 & 0,7 & 49,3 & 30,3 & 11,9 \\
\hline Non-participatie & 0,4 & 0,3 & 0,5 & 0,4 & 0,6 & 0,3 & 0,2 & 0,1 & 0,0 & 3,9 & 93,2 & 100,3 \\
\hline
\end{tabular}


Tabel 25: Beroep en arbeidsmarktpositie tussen kwartalen $t$ en $t+1$ en internationale definitie werkloosheid (1 digit), 2002-2005 (ongewogen)

\begin{tabular}{|c|c|c|c|c|c|c|c|c|c|c|c|c|}
\hline$n^{t+1}$ & $\begin{array}{c}\text { Elementaire } \\
\text { beroepen }\end{array}$ & $\begin{array}{l}\text { Lagere } \\
\text { Beroepen } \\
\text { (techniek } \\
\text { etc) }\end{array}$ & $\begin{array}{c}\text { Lagere adm., } \\
\text { commerciële } \\
\text { beroepen } \\
\text { e.d. }\end{array}$ & $\begin{array}{c}\text { Middelbare } \\
\text { beroepen } \\
\text { (techniek } \\
\text { etc) }\end{array}$ & $\begin{array}{l}\text { Middelbare } \\
\text { adm., } \\
\text { commerciële } \\
\text { beroepen } \\
\text { e.d. }\end{array}$ & $\begin{array}{c}\text { Hogere } \\
\text { beroepen } \\
\text { (techniek } \\
\text { etc) }\end{array}$ & $\begin{array}{c}\text { Hogere } \\
\text { adm., } \\
\text { commerciële } \\
\text { beroepen } \\
\text { e.d. }\end{array}$ & $\begin{array}{l}\text { Wetenschap- } \\
\text { pelijke } \\
\text { beroepen } \\
\text { (techniek } \\
\text { etc) }\end{array}$ & $\begin{array}{l}\text { Wetenschap- } \\
\text { pelijke } \\
\text { economische } \\
\text { adm. } \\
\text { beroepen } \\
\text { e.d. }\end{array}$ & $\begin{array}{l}\text { Werkloos- } \\
\text { heid }\end{array}$ & $\begin{array}{c}\text { Non- } \\
\text { participatie }\end{array}$ & $\begin{array}{c}\mathrm{N} \\
(\mathrm{x} 1000)\end{array}$ \\
\hline Elementaire beroepen & 90,9 & 1,0 & 1,6 & 0,4 & 0,7 & 0,1 & 0,1 & 0,0 & 0,0 & 1,3 & 3,8 & 72,1 \\
\hline $\begin{array}{l}\text { Lagere Beroepen (techniek } \\
\text { etc) }\end{array}$ & 0,6 & 95,3 & 0,4 & 0,6 & 0,3 & 0,1 & 0,1 & 0,0 & 0,0 & 0,8 & 1,7 & 92,3 \\
\hline $\begin{array}{l}\text { Lagere adm., commerciele } \\
\text { beroepen e.d. }\end{array}$ & 0,7 & 0,3 & 93,8 & 0,2 & 1,2 & 0,1 & 0,2 & 0,0 & 0,1 & 0,9 & 2,5 & 107,8 \\
\hline $\begin{array}{l}\text { Middelbare beroepen } \\
\text { (techniek etc) }\end{array}$ & 0,1 & 0,3 & 0,1 & 97,4 & 0,3 & 0,2 & 0,2 & 0,0 & 0,1 & 0,4 & 0,9 & 135,4 \\
\hline $\begin{array}{l}\text { Middelbare adm, } \\
\text { commerciele beroepen e.d. }\end{array}$ & 0,1 & 0,1 & 0,5 & 0,3 & 96,4 & 0,2 & 0,6 & 0,0 & 0,1 & 0,6 & 1,1 & 169,3 \\
\hline $\begin{array}{l}\text { Hogere beroepen (techniek } \\
\text { etc) }\end{array}$ & 0,0 & 0,0 & 0,1 & 0,3 & 0,3 & 97,5 & 0,4 & 0,2 & 0,1 & 0,2 & 0,9 & 75,2 \\
\hline $\begin{array}{l}\text { Hogere adm, commerciele } \\
\text { beroepen e.d. }\end{array}$ & 0,1 & 0,1 & 0,1 & 0,2 & 0,8 & 0,3 & 96,7 & 0,1 & 0,4 & 0,5 & 0,8 & 96,0 \\
\hline $\begin{array}{l}\text { Wetenschappelijke } \\
\text { beroepen (techniek etc) }\end{array}$ & 0,0 & 0,0 & 0,1 & 0,2 & 0,2 & 0,3 & 0,4 & 97,1 & 0,4 & 0,5 & 0,8 & 27,3 \\
\hline $\begin{array}{l}\text { Wetenschappelijke } \\
\text { economische adm. } \\
\text { beroepen e.d. }\end{array}$ & 0,0 & 0,0 & 0,1 & 0,1 & 0,4 & 0,2 & 1,0 & 0,3 & 96,8 & 0,3 & 0,8 & 36,6 \\
\hline Werkloosheid & 5,5 & 3,8 & 6,1 & 2,1 & 4,7 & 1,0 & 1,8 & 0,6 & 0,6 & 44,1 & 29,6 & 26,3 \\
\hline Non-participatie & 1,3 & 0,7 & 1,4 & 0,4 & 0,7 & 0,2 & 0,3 & 0,1 & 0,1 & 3,6 & 91,2 & 245,8 \\
\hline
\end{tabular}




\subsection{Beroepenmobiliteit op 3 digit niveau}

Bijlage 4 bevat een overzicht van de beroepenmobiliteit op 3 digit niveau. Voor de plausibiliteitanalyse is het van belang dat nader inzicht wordt verkregen in hoeverre werknemers na mobiliteit werkzaam zijn in een aan de initiële beroepsgroep verwant beroep. Voor elke beroepsgroep wordt het percentage mensen weergegeven dat werkzaam blijft in de initiële beroepsgroep en het percentage dat werkloos wordt of uittreedt. Daarachter staan van links naar rechts de ontvangende beroepen waarvoor de uitstroom vanuit de initiële beroepsgroep het grootst is. In deze tabel is de ROA 3 digit classificatie gebruikt. Deze classificatie is vrijwel identiek aan de SBC '92 van het CBS en is eenvoudig te herleiden tot de standaardindeling van het CBS, maar wordt door het ROA gebruikt omdat de naamgeving van de beroepsgroepen in deze classificatie de belangrijkste beroepen duidelijk weergeven.

Ook op 3 digit niveau blijkt dat de mobiliteitstromen tussen beroepen plausibel zijn. ${ }^{10}$ Een goed voorbeeld is het beroep leraar basisonderwijs waarvoor maar zeer beperkte substitutiemogelijkheden bestaan. Maar weinig leraren basisonderwijs stromen uit naar een ander beroep $(0,9 \%)$ De leraren die wel uitstromen stromen het vaakst uit naar verwante beroepen zoals onderwijskundig medewerkers. Daarnaast worden leraren ook vaak leidinggevende (directeur van een basisschool). Andere voorbeelden zijn de geestelijk verzorgers en geestelijken die vaak uitstromen naar de verwante beroepen als sociaal-wetenschappelijk medewerkers of activiteitenbegeleiders, en aannemers en installateurs die vaak bouwvakkers, architecten en bouwkundig projectleiders of monteurs worden. De uitstroom naar verwante beroepen valt eveneens waar te nemen voor onder andere de uitstroom van werkenden van de beroepsgroepen artsen, vliegers, scheepskapiteins en leidinggevenden transport, economen, juristen en activiteitenbegeleiders en medewerkers arbeidsbemiddeling.

Daarnaast valt op dat de mobiliteit bijzonder groot is voor beroepen op elementair of lager niveau en voor beroepen die seizoensgebonden zijn. Van de mensen die werkzaam waren als agrarisch hulparbeider is de volgende periode $24,5 \%$ mobiel. Ruim $16,1 \%$ stroomt uit van de arbeidsmarkt. Ook kantoorhulpen, inpakkers en colporteurs zijn vaak mobiel $(14,0 \%)$, waarbij meer dan de helft van de mobiele personen uitstroomt van de arbeidsmarkt. Hetzelfde valt waar te nemen voor interieurverzorgers.

Als werklozen en non-participanten weer aan het werk gaan dan zijn zij vaak werkzaam op elementair of lager niveau. De belangrijkste bestemmingen (naast non-participatie) van werkloze personen zijn de beroepsgroepen boekhouders en secretaresses, verkopers en receptionisten en administratief medewerkers. Non-participanten stromen vaak in in de beroepsgroepen verkopers, hulpkrachten horeca en verzorging en interieurverzorgers.

\subsection{Samenvatting}

Het EBB-panel geeft een lagere mobiliteit op de arbeidsmarkt te zien dan de laatste bekende mobiliteitsgegevens van het SEP. Hier zijn echter goede verklaringen voor te geven, waaronder ook aanwijzingen voor een overschatting van beroepenmobiliteit in het SEP. Het blijkt dat er in het EBB-panel geen vreemde mobiliteitspatronen worden gevonden. Personen met een elementair of lager beroep hebben een zwakkere arbeidsmarktpositie en volgen vaak nog onderwijs, wat terug te vinden is in een grotere

${ }^{10}$ Een uitzondering is de beroepenmobiliteit van bedrijfshoofden metaalbewerking waarvoor het aantal bedrijfshoofden die mobiel zijn te klein is om een betrouwbare mobiliteit te kunnen vast te stellen. 
mobiliteit richting werkloosheid en non-participatie. Daarnaast vindt mobiliteit vooral plaatst naar beroepen van aangrenzende niveaus en dezelfde richting als in het initiële beroep. De naar verhouding grote mobiliteit bij de hogere beroepen in het SEP is daarentegen contra-intuïtief. Volgens verwachting stromen mensen in het EBB-panel die werkloos of non-participant zijn vaak uit naar beroepen op de lagere niveaus. Deze mobiliteitstromen worden zowel gevonden op 1 digit als op 3 digit niveau.

Uit het voorafgaande valt eveneens op te maken dat de uitsplitsing van de beroepenmobiliteit in het EBB-panel over groepen met verschillende achtergrondkenmerken geen verrassingen laat zien. De mobiliteitsstromen voor de verschillende groepen zijn plausibel. Vrouwen zijn iets meer mobiel dan mannen en jongeren en ouderen treden vaker uit de arbeidsmarkt door studie of pensionering. Jongeren tussen de leeftijd van 15 tot en met 24 jaar zijn het meest mobiel. Daarnaast is de gemeten beroepenmobiliteit volgens verwachting kleiner als gebruik wordt gemaakt van de internationale definitie van werkloosheid, vooral onder de laagste beroepenniveaus.

\section{Conclusies}

Het doel van deze studie was om te onderzoeken of op basis van de panelgegevens uit de Enquête Beroepsbevolking (EBB) een adequaat beeld van de beroepenmobiliteit in Nederland kan worden gegeven. Daartoe heeft deze studie geanalyseerd in hoeverre de EBB-paneldata betrouwbaar zijn en is de plausibiliteit van de mobiliteitstromen onderzocht.

De analyse van de betrouwbaarheid van de EBB-paneldata heeft zich gericht op de omvang en selectiviteit van paneluitval en het effect van proxy beantwoording op de kwaliteit van de data. In het algemeen kan worden gesteld dat de kwaliteit van de EBBpaneldata redelijk is voor de onderzochte periode van 2002 tot 2005. De omvang van de paneluitval is niet bijzonder groot en is redelijk constant over de verschillende peilingen. Desalniettemin is er sprake van selectiviteit in de paneluitval. Vooral de uitval onder mobielere groepen is naar verhouding groot: allochtonen, jongeren (15-24 jaar) en lager opgeleiden. Ook kan uitval van personen die zijn verhuisd tot onderschatting van beroepenmobiliteit leiden. Dit geldt met name wanneer de verhuizing het gevolg is van een verandering van beroep. Deze indicaties voor selectiviteit maken een weging van de uitkomsten naar de populatie noodzakelijk. In een afzonderlijke notitie is een weegschema voorgesteld om de beroepenmobiliteit te schatten (Boonstra en Kruiskamp, 2008). Dit weegschema is weergegeven in bijlage 6 .

Als onderdeel van de plausibiliteitsanalyse zijn de EBB-uitkomsten over beroepenmobiliteit vergeleken met die uit het Sociaaleconomisch panelonderzoek (SEP). Er is gekeken naar de plausibiliteit van de omvang en de richting van de mobiliteitstromen. Voor de vergelijking is het SEP in de periode 1995-2001 gekozen. De mobiliteit is vastgesteld voor groepen met verschillende achtergrondkenmerken. Uit de analyse van de beroepenmobiliteit blijkt dat de uitkomsten over beroepenmobiliteit op één digit beroep op basis van het EBB-panel geen implausibele uitkomsten opleveren.

De omvang van de mobiliteit is lager dan is gemeten in het SEP. Echter, de lagere omvang kan grotendeels worden verklaard door het feit dat de SEP jaarlijks werd afgenomen in een periode waarin de baanmobiliteit in Nederland hoger was. Bovendien is aannemelijk dat de beroepenmobiliteit in het SEP wordt overschat als gevolg van de SEP vraagstelling. 
De richting van de mobiliteitsstromen binnen de EBB zijn zoals verwacht. Personen met een elementair of lager beroep zijn vaker mobiel en worden vaker werkloos of inactief. Beroepverlaters vertrekken vooral naar beroepen met aangrenzende niveaus en dezelfde richting als in het initiële beroep. Mensen die werkloos en non-participant zijn, stromen vaak uit naar lagere beroepsniveaus. Deze mobiliteitstromen worden zowel gevonden op 1 digit als op 3 digit niveau. De uitsplitsing van de beroepenmobiliteit in het EBB-panel over groepen met verschillende achtergrondkenmerken laat eveneens geen verrassingen zien. Vrouwen zijn in het EBB-panel iets mobieler dan mannen en jongeren en ouderen treden vaker uit de arbeidsmarkt door studie of pensionering. Jongeren in de leeftijd van 15 tot en met 24 jaar zijn het meest mobiel. Daarnaast is de gemeten beroepenmobiliteit volgens verwachting kleiner als gebruik wordt gemaakt van de internationale definitie van werkloosheid.

De vraagstelling naar beroepenmobiliteit in de EBB leidt mogelijk tot een geringe onderschatting van de beroepenmobiliteit omdat alleen aan de respondenten die van werkgever zijn veranderd altijd het beroep opnieuw wordt vastgesteld. Voor de respondenten die niet van werkgever zijn gewisseld, wordt het beroep alleen opnieuw vastgesteld als ze aangeven van beroep gewisseld te zijn. Uit de literatuur blijkt dat het alternatief dat ook bij het SEP is toegepast, namelijk om voor iedere respondent los van zijn uitgangssituatie het beroep steeds opnieuw vast te stellen, tot een aanzienlijke overschatting van de beroepenmobiliteit leidt.

Ten slotte dient te worden opgemerkt dat voor deze (haalbaarheids)studie in de afbakening van beroepenmobiliteit bepaalde keuzes zijn gemaakt. Deze keuzes zijn niet per se dezelfde als die welke voor een reguliere statistiek over beroepenmobiliteit gemaakt worden. In een aparte notitie komt de vraag aan de orde welke afbakening van beroepenmobiliteit het meest de reguliere productie dient. Deze notitie biedt daarvoor enkele aanknopingspunten.

\section{Literatuur}

Boonstra, H.J en P. Kruiskamp (2008), Weging beroepenmobiliteit, augustus, interne CBS nota, BPA: DMH-2008-08-14-HBTA.

CBS (2001), Standaard Beroepenclassificatie 1992, editie 2001: http://www.cbs.n1/NR/rdonlyres/C2412D09-BC83-464B-BAE3-

E1CBF07B3731/0/sbc.pdf

CBS (1989), Standaard Onderwijsindeling SOI-1978, editie 1989.

CBS (2008), Banen van werknemers; baandynamiek, Statline-publicatie:

http://statline.cbs.nl/StatWeb/publication/?DM=SLNL\&PA=71792NED\&D1=12-

$17 \& \mathrm{D} 2=\mathrm{a} \& \mathrm{D} 3=0 \& \mathrm{D} 4=0 \& \mathrm{D} 5=\mathrm{a} \& \mathrm{HDR}=\mathrm{T}, \mathrm{G} 3 \& \mathrm{STB}=\mathrm{G} 1, \mathrm{G} 2, \mathrm{G} 4 \& \mathrm{VW}=\mathrm{T}$

CPB (2007), Centraal Economisch Plan 2007, april, Den Haag.

Europese Raad van Ministers (2005), Herziene Lissabonstrategie 2005, Brussel.

ILO (1987), Revision of the International Standard Classification of Occupations, part I Background, Principles and Draft Resolution, Genève.

Mathiowetz, N.A. (1992), Error in Reports of Occupations, Public Opinion Quarterly, $56,31-62$.

Moscarini, G. en K. Thomsson (2007), Occupational and Job mobility in the US, Scandinavian Journal of Economics, 109, 807-836.

OSA (2006), Trendrapport Aanbod van arbeid 2005, Tilburg.

Polivka, A.E. en J.M. Rothgeb (1993), Redesigning the CPS Questionnaire, Monthly Labor Review, 116, 210-242. 
ROA (2007), De arbeidsmarkt naar opleiding en beroep tot 2012, ROA-R-2007/4, Maastricht.

SCP (2004), In het zicht van de toekomst: Sociaal en Cultureel Rapport 2004, Den Haag. 
Bijlage 1: EBB vragenlijstschema beroep

EBB 2005 - Beroep (1)

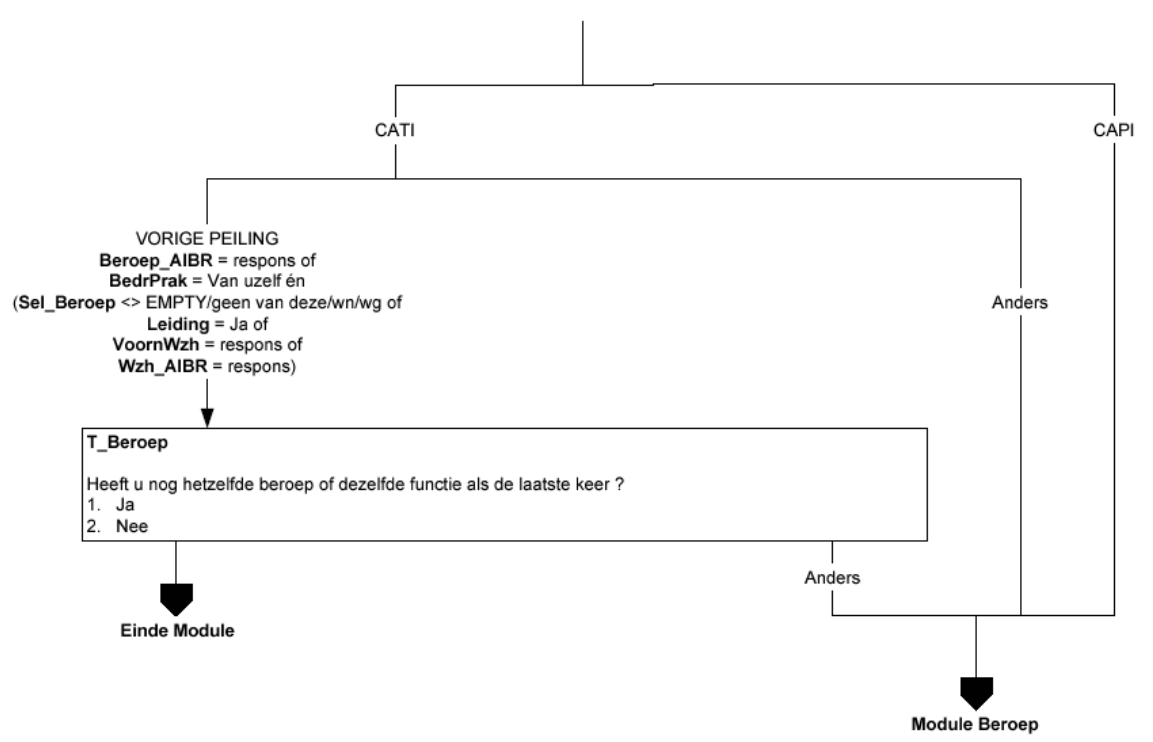


Alleen als Leeftijd $>=15$,

Tyds bestB.UrenWeek $>=12$ uur of TydsbestB.IsHetDan $>=12$ uur

anders Blok werkzoeken

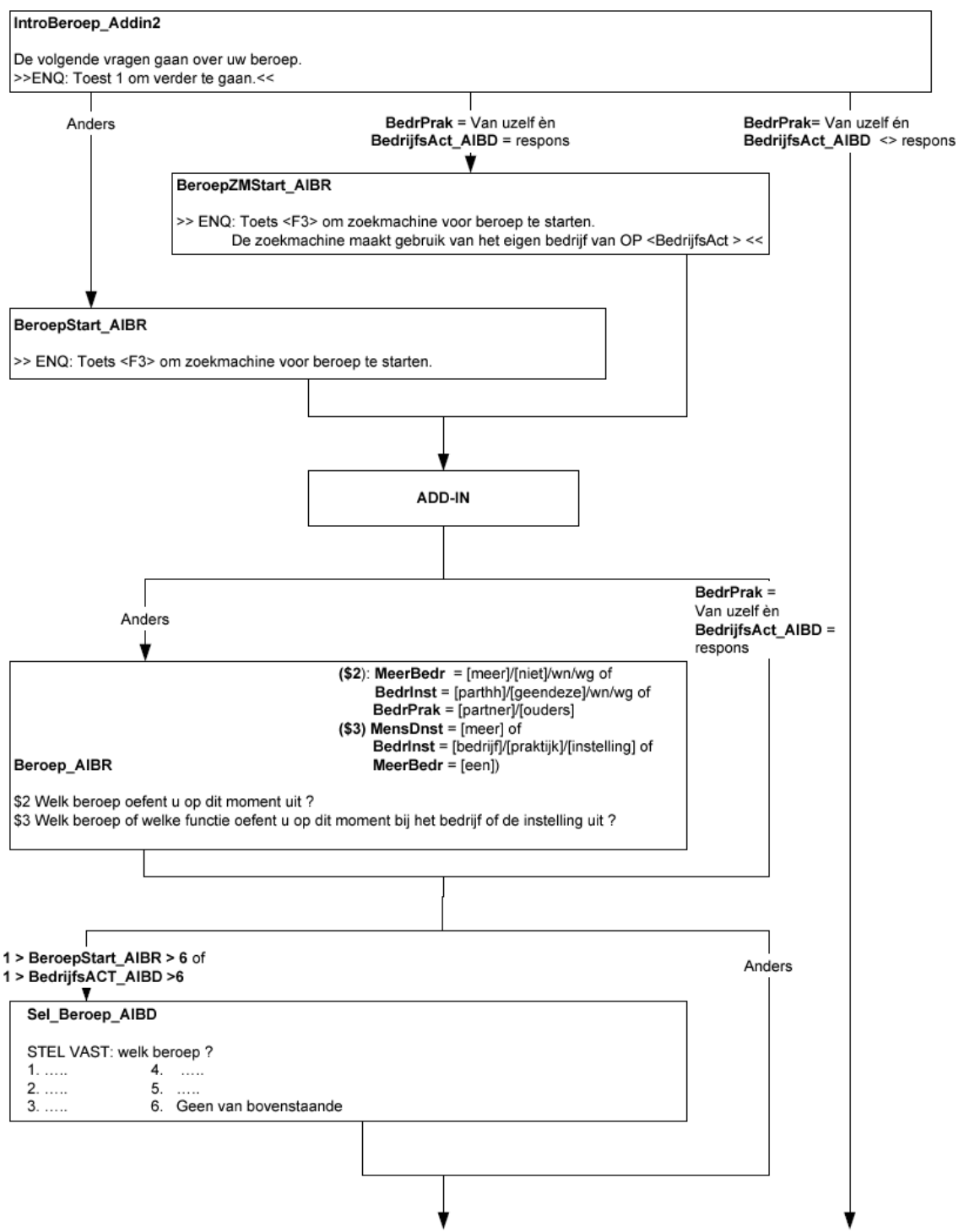




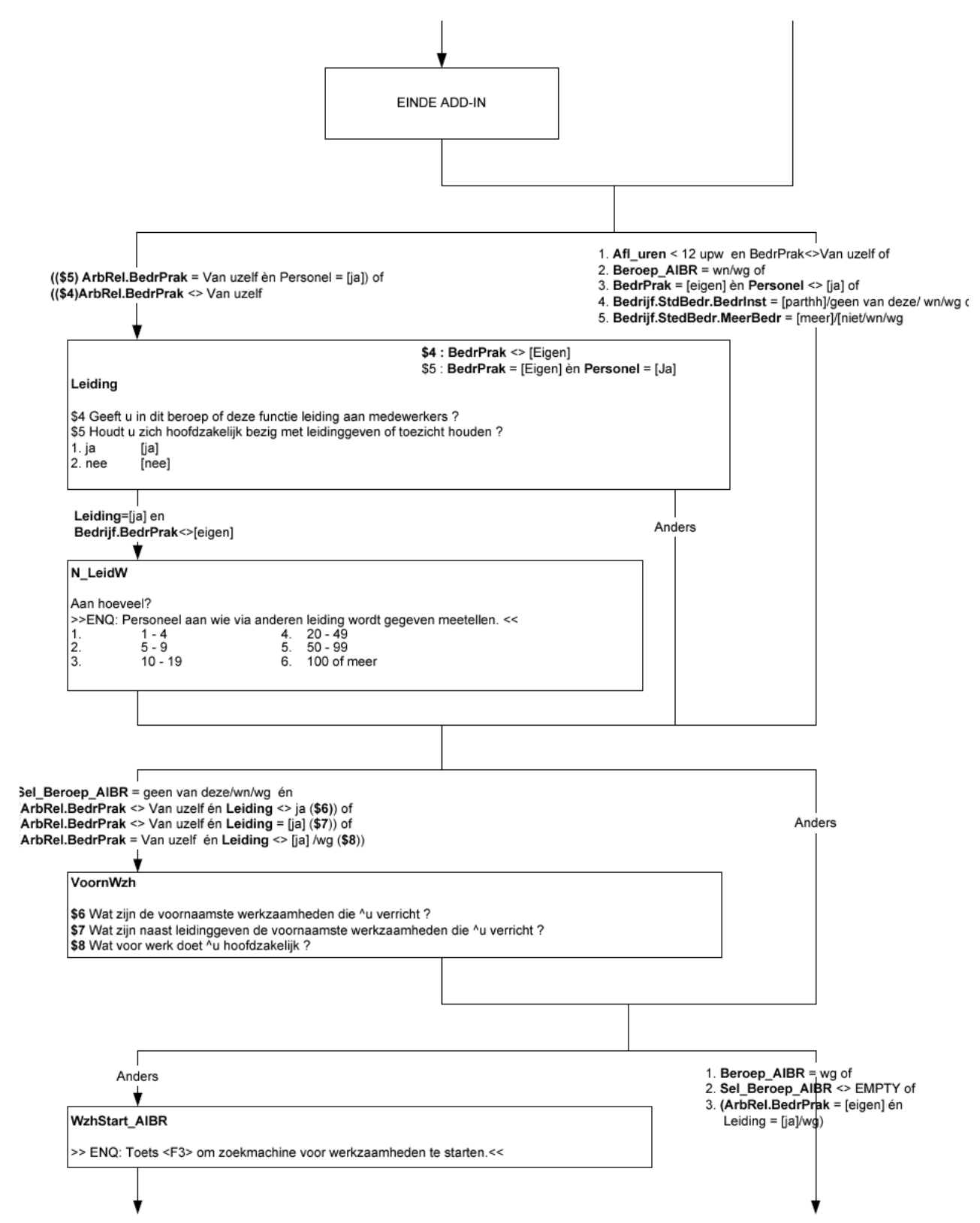




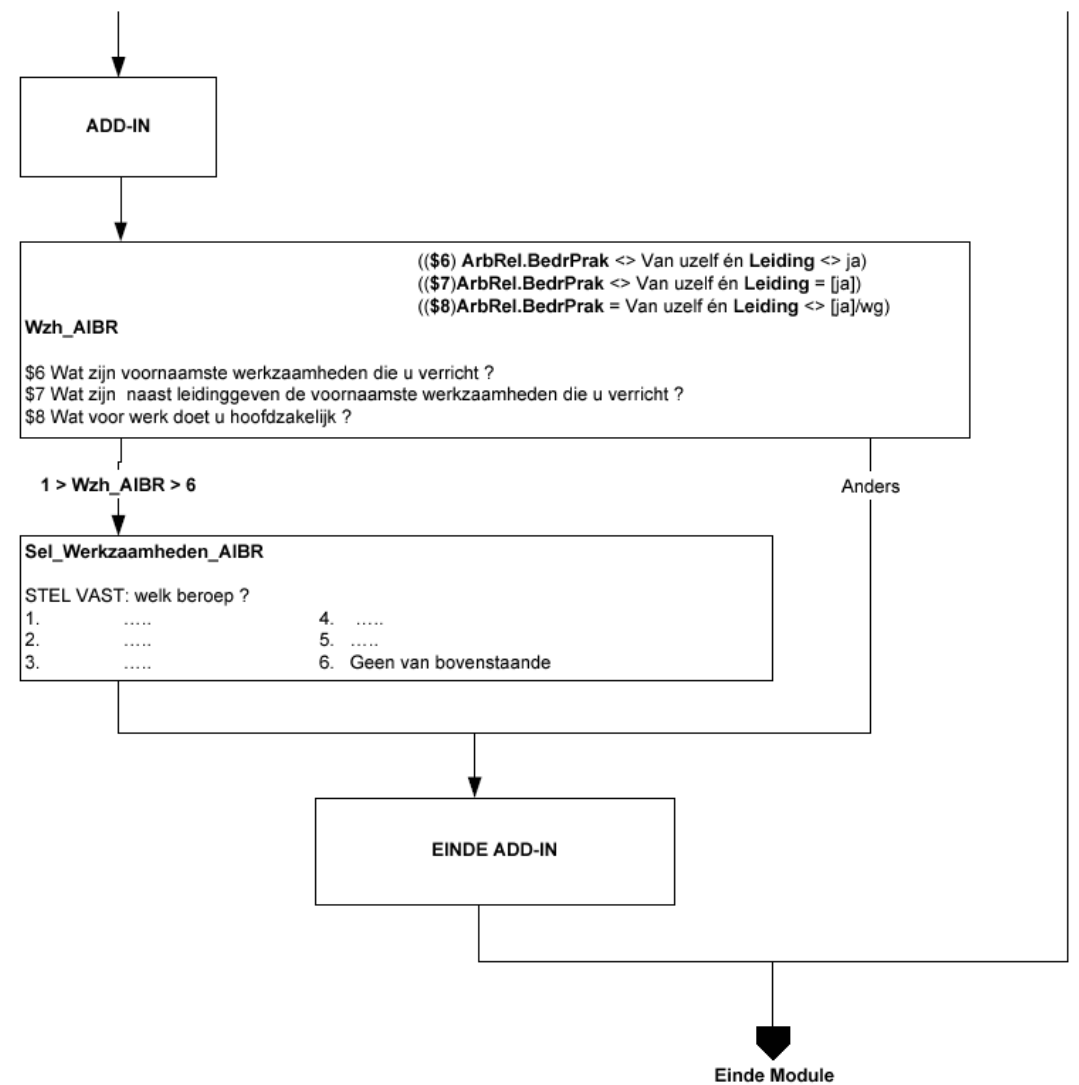




\section{Bijlage 2: Paneluitval uitkomsten}

Tabel B2.1: Aantal respondenten in de EBB naar geslacht en per peilnummer, 15-64 jaar,

\begin{tabular}{|c|c|c|c|c|}
\multicolumn{2}{|c|}{$2002-2005$} & \multicolumn{2}{|c|}{ Vrouw } \\
\hline \multirow{2}{*}{ Peilnummer } & \multicolumn{2}{|c|}{ Man } & & \\
1 & & & & \\
2 & 1600 & $\%$ van $1^{\mathrm{e}}$ peiling & x 1000 & $\%$ van $1^{\mathrm{e}}$ peiling \\
2 & 130 & 100 & 170 & 100 \\
3 & 122 & 78 & 132 & 78 \\
4 & 116 & 73 & 124 & 73 \\
5 & 111 & 67 & 117 & 69 \\
& & & 112 & 66 \\
\hline
\end{tabular}

Tabel B2.2: Aantal respondenten in de EBB naar herkomst en per peilnummer, 15-64 jaar, 2002-2005

\begin{tabular}{|c|c|c|c|c|c|c|}
\hline & \multicolumn{2}{|c|}{ Autochtoon } & \multicolumn{2}{|c|}{ Westerse allochtoon } & \multicolumn{2}{|c|}{ Niet-westerse allochtoon } \\
\hline Peilnummer & x 1000 & $\begin{array}{c}\% \text { van } 1^{e} \\
\text { peiling }\end{array}$ & x 1000 & $\begin{array}{c}\% \text { van } 1^{e} \\
\text { peiling }\end{array}$ & x 1000 & $\begin{array}{c}\% \text { van } 1^{e} \\
\text { peiling }\end{array}$ \\
\hline 1 & 288 & 100 & 25 & 100 & 23 & 100 \\
\hline 2 & 231 & 80 & 18 & 73 & 13 & 57 \\
\hline 3 & 218 & 75 & 17 & 67 & 11 & 50 \\
\hline 4 & 207 & 72 & 16 & 63 & 10 & 44 \\
\hline 5 & 200 & 69 & 15 & 60 & 9 & 41 \\
\hline
\end{tabular}

Tabel B2.3: Aantal respondenten in de EBB naar leeftijd en per peilnummer, 15-64 jaar,

\begin{tabular}{|c|c|c|c|c|c|c|}
\hline & \multicolumn{2}{|c|}{ 15-24 jaar } & \multicolumn{2}{|c|}{ 25-34 jaar } & \multicolumn{2}{|c|}{ 35-44 jaar } \\
\hline Peilnummer & x 1000 & $\begin{array}{c}\% \text { van } 1^{e} \\
\text { peiling }\end{array}$ & x 1000 & $\begin{array}{c}\% \text { van } 1^{e} \\
\text { peiling }\end{array}$ & x 1000 & $\begin{array}{c}\% \text { van } 1^{e} \\
\text { peiling }\end{array}$ \\
\hline 1 & 57 & 100 & 65 & 100 & 82 & 100 \\
\hline 2 & 42 & 75 & 50 & 77 & 66 & 81 \\
\hline 3 & 38 & 67 & 46 & 71 & 63 & 77 \\
\hline 4 & 35 & 61 & 42 & 65 & 60 & 73 \\
\hline 5 & 32 & 57 & 39 & 60 & 58 & 71 \\
\hline
\end{tabular}


Tabel B2.4: Aantal respondenten in de EBB naar leeftijd en per peilnummer, 15-64 jaar, 2002-2005 (vervolg)

\begin{tabular}{|c|c|c|c|c|}
\hline & \multicolumn{2}{|c|}{ 45-54 jaar } & \multicolumn{2}{|c|}{ 55-64 jaar } \\
\hline Peilnummer & x 1000 & $\%$ van $1^{e}$ peiling & x 1000 & $\%$ van $1^{e}$ peiling \\
\hline 1 & 73 & 100 & 60 & 100 \\
\hline 2 & 58 & 80 & 45 & 75 \\
\hline 3 & 56 & 76 & 43 & 73 \\
\hline 4 & 54 & 74 & 42 & 71 \\
\hline 5 & 53 & 72 & 42 & 70 \\
\hline
\end{tabular}

Tabel B2.5: Aantal respondenten in de EBB naar hoogstbehaalde opleidingsniveau en per peilnummer, 15-64 jaar, 2002-2005

\begin{tabular}{|l|c|c|c|c|c|c|}
\hline \multicolumn{9}{|c|}{ Basisonderwijs } & \multicolumn{2}{c|}{ Vmbo } \\
\hline \multirow{3}{*}{ Peilnummer } & $\times 1000$ & $\begin{array}{c}\text { \% van } 1^{e} \\
\text { peiling }\end{array}$ & x 1000 & $\begin{array}{c}\text { \% van } 1^{e} \\
\text { peiling }\end{array}$ & x 1000 & $\begin{array}{c}\text { \% van } 1^{e} \\
\text { peiling }\end{array}$ \\
1 & 33 & 100 & 85 & 100 & 138 & 100 \\
3 & 21 & 65 & 64 & 76 & 110 & 80 \\
4 & 19 & 57 & 60 & 71 & 104 & 75 \\
5 & 17 & 51 & 57 & 66 & 99 & 72 \\
& 15 & 47 & 54 & 64 & 96 & 70 \\
\hline
\end{tabular}

Tabel B2.6: Aantal respondenten in de EBB naar hoogstbehaalde opleidingsniveau en per peilnummer, 15-64 jaar, 2002-2005 (vervolg)

\begin{tabular}{|c|c|c|c|c|c|c|}
\hline \multicolumn{9}{|c|}{ Hbo } & \multicolumn{2}{c|}{ Onbekend } \\
\hline \multirow{3}{*}{ Peilnummer } & x 1000 & $\begin{array}{c}\text { Wo van } 1^{e} \\
\text { peiling }\end{array}$ & x 1000 & $\begin{array}{c}\text { \% van } 1^{e} \\
\text { peiling }\end{array}$ & x 1000 & $\begin{array}{c}\text { \% van } 1^{e} \\
\text { peiling }\end{array}$ \\
1 & 53 & 100 & 27 & 100 & 1 & 100 \\
2 & 44 & 83 & 22 & 82 & 1 & 59 \\
3 & 42 & 79 & 21 & 77 & 1 & 51 \\
4 & 40 & 76 & 20 & 74 & 1 & 46 \\
5 & 39 & 74 & 19 & 71 & 1 & 44 \\
\hline
\end{tabular}


Tabel B2.7: Proxy beantwoording en verandering van beroepencode naar leeftijd (alle peilingen), 2002-2005

\begin{tabular}{|l|c|c|c|c|c|}
\hline & & & & & \\
& $\begin{array}{c}15-24 \text { jaar } \\
\%\end{array}$ & $\begin{array}{c}25-34 \text { jaar } \\
\%\end{array}$ & $\begin{array}{c}35-44 \text { jaar } \\
\%\end{array}$ & $\begin{array}{c}45-54 \text { jaar } \\
\%\end{array}$ & $\begin{array}{c}55-64 \text { jaar } \\
\text { Beantwoording }\end{array}$ \\
Beide zelf & 3,3 & 2,7 & 1,7 & 1,2 & 0,3 \\
Zelf en proxy & 2,7 & 3,0 & 2,1 & 1,5 & 0,4 \\
Beide proxy & 1,8 & 2,6 & 1,8 & 1,2 & 0,4 \\
& & & & & \\
\hline
\end{tabular}

Tabel B2.8: Proxy beantwoording en verandering van beroepencode naar herkomst (alle peilingen), 2002-2005

\begin{tabular}{|l|c|c|c|}
\hline & Autochtoon & Westerse allochtoon & Niet-westerse allochtoon \\
& $\%$ & $\%$ & $\%$ \\
\hline Beantwoording & & & 1,8 \\
Beide zelf & 1,6 & 1,7 & 1,9 \\
Zelf en proxy & 1,8 & 1,9 & 1,4 \\
Beide proxy & 1,7 & 1,5 & \\
\hline
\end{tabular}


Tabel B2.9: Aantal respondenten waarvan de beroepencode bekend is in de EBB, naar geslacht en per peilnummer, 15-64 jaar, 2002-2005

\begin{tabular}{|l|c|c|c|c|}
\hline \multicolumn{2}{|c|}{ Man } & \multicolumn{2}{c|}{ Vrouw } \\
\hline \multirow{2}{*}{ Peilnummer } & x 1000 & \% van $1^{e}$ peiling & x 1000 & \% van $1^{e}$ peiling \\
1 & 133 & 100 & 109 & 100 \\
2 & 107 & 80 & 89 & 77 \\
3 & 101 & 76 & 84 & 73 \\
5 & 95 & 72 & 80 & 77 \\
\hline
\end{tabular}

Tabel B2.10: Aantal respondenten waarvan de beroepencode bekend is in de EBB, naar herkomst en per peilnummer, 15-64 jaar, 2002-2005

\begin{tabular}{|c|c|c|c|c|c|c|}
\hline & \multicolumn{2}{|c|}{ Autochtoon } & \multicolumn{2}{|c|}{ Westerse allochtoon } & \multicolumn{2}{|c|}{ Niet-westerse allochtoon } \\
\hline Peilnummer & X 1000 & $\begin{array}{c}\% \text { van } 1^{e} \\
\text { peiling }\end{array}$ & x 1000 & $\begin{array}{c}\% \text { van } 1^{e} \\
\text { peiling }\end{array}$ & x 1000 & $\begin{array}{c}\% \text { van } 1^{e} \\
\text { peiling }\end{array}$ \\
\hline 1 & 214 & 100 & 17 & 100 & 12 & 100 \\
\hline 2 & 176 & 82 & 13 & 76 & 8 & 64 \\
\hline 3 & 166 & 78 & 12 & 71 & 7 & 57 \\
\hline 4 & 158 & 74 & 11 & 67 & 6 & 51 \\
\hline 5 & 152 & 71 & 11 & 64 & 6 & 49 \\
\hline
\end{tabular}

Tabel B2.11: Aantal respondenten waarvan de beroepencode bekend is in de EBB, naar leeftijd en per peilnummer, 15-64 jaar, 2002-2005

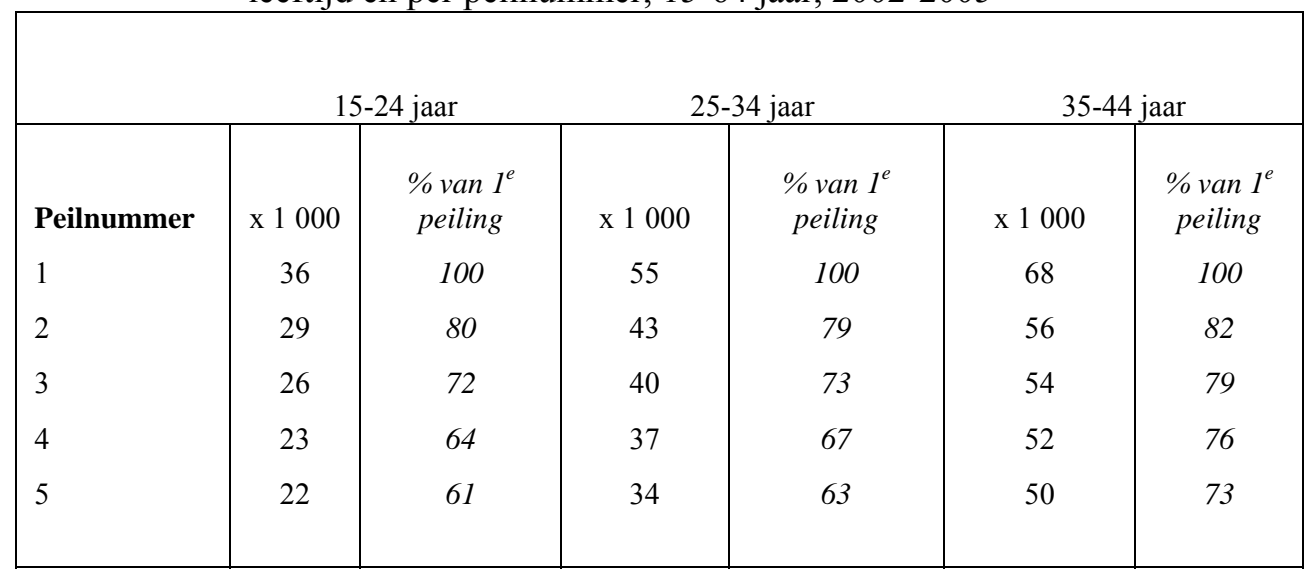


Tabel B2.12: Aantal respondenten waarvan de beroepencode bekend is in de EBB, naar leeftijd en per peilnummer, 15-64 jaar, 2002-2005 (vervolg)

\begin{tabular}{|l|c|c|c|c|}
\hline \multicolumn{2}{|c|}{ 45-54 jaar } & \multicolumn{2}{c|}{ 55-64 jaar } \\
\hline \multirow{3}{*}{ Peilnummer } & x 1000 & \% van 1 peiling & x 1000 & $\%$ van $1^{e}$ peiling \\
1 & 57 & 100 & 26 & 100 \\
2 & 47 & 82 & 21 & 80 \\
3 & 45 & 79 & 20 & 78 \\
4 & 44 & 77 & 20 & 77 \\
5 & 43 & 76 & 20 & 77 \\
\hline
\end{tabular}

Tabel B2.13: Aantal respondenten waarvan de beroepencode bekend is in de EBB, naar hoogstbehaalde opleidingsniveau en per peilnummer,15-64 jaar, 2002-2005

\begin{tabular}{|l|c|c|c|c|c|c|}
\hline \multicolumn{9}{|c|}{ Basisonderwijs } & \multicolumn{2}{c|}{ Mbo, Havo, Vwo } \\
\hline \multirow{2}{*}{ Peilnummer } & $\times 1000$ & $\begin{array}{c}\text { \% van } 1^{e} \\
\text { peiling }\end{array}$ & x 1000 & $\begin{array}{c}\text { \% van } 1^{e} \\
\text { peiling }\end{array}$ & x 1000 & $\begin{array}{c}\text { \% van } 1^{e} \\
\text { peiling }\end{array}$ \\
1 & 15 & 100 & 53 & 100 & 106 & 100 \\
2 & 10 & 72 & 42 & 79 & 87 & 82 \\
3 & 9 & 64 & 39 & 74 & 82 & 77 \\
4 & 9 & 58 & 37 & 70 & 78 & 74 \\
5 & 8 & 55 & 36 & 68 & 76 & 72 \\
\hline
\end{tabular}

Tabel B2.14: Aantal respondenten waarvan de beroepencode bekend is in de EBB, naar hoogstbehaalde opleidingsniveau en per peilnummer, 15-64 jaar, 2002-2005 (vervolg)

\begin{tabular}{|l|c|c|c|c|c|c|}
\hline \multicolumn{1}{|c|}{ Hbo } \\
\hline \multirow{2}{*}{ Peilnummer } & x 1000 & $\begin{array}{c}\text { W van } 1^{e} \\
\text { peiling }\end{array}$ & x 1000 & $\begin{array}{c}\text { Onbekend } \\
\text { \% van } 1^{e} \\
\text { peiling }\end{array}$ & x 1000 & $\begin{array}{c}\text { \% van } 1^{e} \\
\text { peiling }\end{array}$ \\
2 & 44 & 100 & 23 & 100 & 1 & 100 \\
3 & 37 & 84 & 19 & 83 & 1 & 65 \\
4 & 36 & 81 & 18 & 79 & 0 & 56 \\
5 & 34 & 77 & 17 & 75 & 0 & 52 \\
& 33 & 75 & 17 & 72 & 0 & 49 \\
\hline
\end{tabular}


Tabel B2.15: Verandering van beroepencode per peiling op vijf digit niveau, naar geslacht, 2002-2005

\begin{tabular}{|l|c|c|c|c|}
\hline & Man & \multicolumn{2}{c|}{ \% van totale } & \multicolumn{2}{c|}{ Vrouw } & \multicolumn{1}{c|}{$\begin{array}{c}\text { \% van totale } \\
\text { Verandering beroepencode }\end{array}$} & x 1000 & $N^{*}$ & 1000 & 1,9 \\
\hline Peiling 1 - peiling 2 & 2,3 & 2,2 & 1,7 & 2,0 \\
Peiling 2 - peiling 3 & 2,3 & 2,3 & 1,7 & 1,9 \\
Peiling 3 - peiling 4 & 2,1 & 2,2 & 1,6 & 1,8 \\
Peiling 4 - peiling 5 & 2,0 & 2,1 & 1,4 & \\
Totaal & 8,7 & & 6,3 & \\
\hline
\end{tabular}

* Hiervoor is het aantal personen met een verandering van beroepencode gedeeld door het aantal personen waarvan de beroepencode bekend is (peiling $2 \mathrm{t} / \mathrm{m}$ peiling 5; tabel 7)

Tabel B2.16: Verandering van beroepencode per peiling op vijf digit niveau, naar herkomst, 2002-2005

\begin{tabular}{|c|c|c|c|c|c|c|}
\hline $\begin{array}{l}\text { Verandering } \\
\text { beroepencode }\end{array}$ & $\begin{array}{l}\text { Autoch- } \\
\text { toon } \\
\times 1000\end{array}$ & $\begin{array}{c}\% \text { van } \\
\text { totale } N^{*}\end{array}$ & $\begin{array}{l}\text { Westerse } \\
\text { allochtoon } \\
\text { x } 1000 \\
\end{array}$ & $\begin{array}{c}\% \text { van } \\
\text { totale } N^{*}\end{array}$ & $\begin{array}{c}\text { Niet- } \\
\text { westerse } \\
\text { allochtoon } \\
\text { x } 1000\end{array}$ & $\begin{array}{c}\% \text { van } \\
\text { totale } N^{*}\end{array}$ \\
\hline Peiling 1 - peiling 2 & 3,5 & 2,0 & 0,3 & 2,3 & 0,2 & 2,7 \\
\hline Peiling 2 - peiling 3 & 3,5 & 2,1 & 0,2 & 2,1 & 0,2 & 2,6 \\
\hline Peiling 3 - peiling 4 & 3,3 & 2,1 & 0,2 & 2,2 & 0,1 & 2,3 \\
\hline Peiling 4 - peiling 5 & 3,0 & 2,0 & 0,2 & 2,1 & 0,1 & 2,1 \\
\hline Totaal & 13,3 & & 1,0 & & 0,7 & \\
\hline
\end{tabular}

* Hiervoor is het aantal personen met een verandering van beroepencode gedeeld door het aantal personen waarvan de beroepencode bekend is (peiling $2 \mathrm{t} / \mathrm{m}$ peiling 5 ; tabel 8 )

Tabel B2.17: Verandering van beroepencode per peiling op vijf digit niveau, naar leeftijd, 2002-2005

\begin{tabular}{|l|c|c|c|c|c|c|}
\hline $\begin{array}{l}\text { Verandering } \\
\text { beroepencode }\end{array}$ & $\begin{array}{c}15-24 \text { jaar } \\
\text { x 1 000 }\end{array}$ & $\begin{array}{c}\text { \% van } \\
\text { totale } N^{*}\end{array}$ & $\begin{array}{c}25-34 \text { jaar } \\
\text { x 1 000 }\end{array}$ & $\begin{array}{c}\text { \% van } \\
\text { totale } N^{*}\end{array}$ & $\begin{array}{c}35-44 \text { jaar } \\
\text { x 1 000 }\end{array}$ & $\begin{array}{c}\% \text { van } \\
\text { totale } N^{*}\end{array}$ \\
\hline Peiling 1 - peiling 2 & 0,9 & 3,2 & 1,3 & 2,9 & 1,0 & 1,8 \\
Peiling 2 - peiling 3 & 0,8 & 2,9 & 1,2 & 3,0 & 1,1 & 2,1 \\
Peiling 3 - peiling 4 & 0,7 & 2,9 & 1,2 & 3,2 & 1,1 & 2,1 \\
Peiling 4 - peiling 5 & 0,6 & 2,8 & 1,0 & 2,9 & 1,0 & 2,1 \\
Totaal & 2,9 & & 4,6 & & 4,3 & \\
\hline
\end{tabular}


Tabel B2.18: Verandering van beroepencode per peiling op vijf digit niveau, naar leeftijd, 2002-2005 (vervolg)

\begin{tabular}{|c|c|c|c|c|}
\hline Verandering beroepencode & $\begin{array}{c}45-54 \text { jaar } \\
\times 1000\end{array}$ & $\begin{array}{c}\% \text { van } \\
\text { totale } N^{*}\end{array}$ & $\begin{array}{c}55-64 \text { jaar } \\
\times 1000\end{array}$ & $\begin{array}{c}\% \text { van totale } \\
N^{*}\end{array}$ \\
\hline Peiling 1 - peiling 2 & 0,6 & 1,4 & 0,2 & 0,7 \\
\hline Peiling 2 - peiling 3 & 0,7 & 1,5 & 0,2 & 0,8 \\
\hline Peiling 3 - peiling 4 & 0,6 & 1,4 & 0,1 & 0,7 \\
\hline Peiling 4 - peiling 5 & 0,6 & 1,4 & 0,1 & 0,6 \\
\hline Totaal & 2,5 & & 5,8 & \\
\hline
\end{tabular}

* Hiervoor is het aantal personen met een verandering van beroepencode gedeeld door het aantal personen waarvan de beroepencode bekend is (peiling $2 \mathrm{t} / \mathrm{m}$ peiling 5 ; tabel 9)

Tabel B2.19: Verandering van beroepencode per peiling op vijf digit niveau, naar hoogstbehaalde opleidingsniveau, 2002-2005

\begin{tabular}{|c|c|c|c|c|c|c|}
\hline $\begin{array}{l}\text { Verandering } \\
\text { beroepencode }\end{array}$ & $\begin{array}{c}\text { Basison- } \\
\text { derwijs } \\
\text { x } 1000\end{array}$ & $\begin{array}{c}\% \text { van } \\
\text { totale } N^{*}\end{array}$ & $\begin{array}{r}\text { Vmbo } \\
\times 1000\end{array}$ & $\begin{array}{c}\% \text { van } \\
\text { totale } N^{*}\end{array}$ & $\begin{array}{c}\text { Mbo, } \\
\text { Havo, } \\
\text { Vwo } \\
\times 1000\end{array}$ & $\begin{array}{c}\% \text { van } \\
\text { totale } N^{*}\end{array}$ \\
\hline Peiling 1 - peiling 2 & 0,2 & 1,5 & 0,8 & 1,9 & 1,7 & 2,0 \\
\hline Peiling 2 - peiling 3 & 0,1 & 1,4 & 0,7 & 1,7 & 1,6 & 2,0 \\
\hline Peiling 3 - peiling 4 & 0,1 & 1,1 & 0,6 & 1,5 & 1,5 & 1,9 \\
\hline Peiling 4 - peiling 5 & 0,1 & 1,1 & 0,5 & 1,5 & 1,2 & 1,6 \\
\hline Totaal & 0,5 & & 2,6 & & 6,0 & \\
\hline
\end{tabular}

Tabel B2.20: Verandering van beroepencode per peiling op vijf digit niveau, naar hoogstbehaalde opleidingsniveau, 2002-2005 (vervolg)

\begin{tabular}{|c|c|c|c|c|c|c|}
\hline \multirow[b]{2}{*}{$\begin{array}{c}\text { Verandering } \\
\text { beroepencode }\end{array}$} & \multicolumn{6}{|c|}{ Hoogst behaalde opleidingsniveau } \\
\hline & $\begin{array}{c}\text { Hbo } \\
\times 1000 \\
\end{array}$ & $\begin{array}{c}\% \text { van } \\
\text { totale } N^{*}\end{array}$ & $\begin{array}{c}\text { Wo } \\
\times 1000 \\
\end{array}$ & $\begin{array}{c}\% \text { van } \\
\text { totale } N^{*}\end{array}$ & $\begin{array}{c}\text { Onbekend } \\
\text { x } 1000 \\
\end{array}$ & $\begin{array}{c}\% \text { van } \\
\text { totale } N^{*}\end{array}$ \\
\hline Peiling 1 - peiling 2 & 0,9 & 2,4 & 0,5 & 2,4 & 0,0 & - \\
\hline Peiling 2 - peiling 3 & 0,8 & 2,3 & 0,4 & 2,4 & 0,2 & - \\
\hline Peiling 3 - peiling 4 & 0,8 & 2,2 & 0,4 & 2,3 & 0,4 & - \\
\hline Peiling 4 - peiling 5 & 0,6 & 1,7 & 0,3 & 2,0 & 0,6 & - \\
\hline Totaal & 3,0 & & 1,6 & & 1,3 & \\
\hline
\end{tabular}

* Hiervoor is het aantal personen met een verandering van beroepencode gedeeld door het aantal personen waarvan de beroepencode bekend is (peiling $2 \mathrm{t} / \mathrm{m}$ peiling 5 ; tabel 10) 


\section{Bijlage 3: Beroepenmobiliteit naar uren en digit niveau}

In tabel B3.1 wordt ingegaan op verschillen in het aantal werkenden met een baan van $\geq 12$ uur per week en werkenden met een baan van $\geq 1$ uur per week, voor de periode 2002-2005. Voor de vijf peilingen samen zijn er 820 duizend personen met een baan van $\geq 12$ uur per week en 930 duizend personen met een baan van $\geq 1$ uur per week. In tabel B3.2 is dit weergegeven naar leeftijd. De verwachting is namelijk dat kleine baantjes van minder dan 12 uur per week vooral onder jongeren voorkomt. Dit blijkt inderdaad het geval te zijn. Het verschil in het aantal werkenden met een baan van $\geq 12$ uur per week en werkenden met een baan $\geq 1$ uur per week is bij 15-24 jarigen veel groter dan bij de andere leeftijdsgroepen.

Tabel B3.1: Aantal personen werkzaam in een baan van $\geq 1$ uur per week en aantal personen werkzaam in een baan van $\geq 12$ uur per week, per peiling, 2002-2005

\begin{tabular}{|c|c|c|}
\hline Peiling & $\begin{array}{c}\text { Werkzaam in baan van } \geq 12 \\
\text { uur per week } \\
\mathrm{N}(\mathrm{x} 1000)\end{array}$ & $\begin{array}{c}\text { Werkzaam in baan van } \\
\geq \text { luur per week } \\
\mathrm{N}\left(\begin{array}{lll}\mathrm{x} & 1 & 000)\end{array}\right)\end{array}$ \\
\hline Peiling 1 & 215 & 243 \\
\hline Peiling 2 & 169 & 193 \\
\hline Peiling 3 & 156 & 177 \\
\hline Peiling 4 & 144 & 163 \\
\hline Peiling 5 & 136 & 155 \\
\hline Totaal & 820 & 930 \\
\hline
\end{tabular}

Tabel B3.2: Aantal personen werkzaam in een baan van $\geq 1$ uur per week en aantal personen werkzaam in een baan van $\geq 12$ uur per week, naar leeftijd, 2002-2005

\begin{tabular}{|l|c|c|}
\hline Leeftijd & $\begin{array}{c}\text { Werkzaam in baan van } \geq 12 \\
\text { uur per week } \\
\mathrm{N}(\mathrm{x} 1000)\end{array}$ & $\begin{array}{c}\text { Werkzaam in baan van } \\
\geq 1 \text { uur per week } \\
\mathrm{N}(\mathrm{x} 1000)\end{array}$ \\
\hline 15-24 jaar & 77 & 131 \\
$25-34$ jaar & 194 & 204 \\
$35-44$ jaar & 252 & 270 \\
$45-54$ jaar & 211 & 226 \\
$55-64$ jaar & 87 & 99 \\
Totaal & 820 & 930 \\
\hline
\end{tabular}

Tabel B3.3 vermeldt de verschillen in beroepenmobiliteit tussen werkenden met een baan van $\geq 12$ uur per week en werkenden met een baan van $\geq 1$ uur per week. In tabel B3.4 is 
dit weergegeven naar leeftijd. Ook hier vinden we de grootste verschillen in de beroepenmobiliteit tussen werkenden met een baan van $\geq 12$ uur en $\geq 1$ uur per week bij de jongeren van 15-24 jaar.

Tabel B3.3: Verandering van beroepende per peiling op vijf digit niveau voor werkenden met een baan van 1 uur per week of meer en voor werkenden met een baan van 12 uur per week of meer, per peiling, 2002-2005

\begin{tabular}{|l|c|c|}
\hline Verandering beroepencode & $\begin{array}{c}\text { Werkzaam in baan van } \geq 12 \\
\text { uur per week } \\
\mathrm{N}(\mathrm{x} \mathrm{1} \mathrm{000)}\end{array}$ & $\begin{array}{c}\text { Werkzaam in baan van } \\
\geq 1 \text { uur per week } \\
\mathrm{N}(\mathrm{x} 1000)\end{array}$ \\
\hline Peiling 1 - peiling 2 & 4,0 & 5,6 \\
Peiling 2 - peiling 3 & 3,9 & 5,6 \\
Peiling 3 - peiling 4 & 3,7 & 5,2 \\
Peiling 4 - peiling 5 & 3,3 & 4,7 \\
Totaal & 14,9 & 21,1 \\
\hline
\end{tabular}

Tabel B3.4: Verandering van beroepencode per peiling op vijf digit niveau voor werkenden met een baan van 1 uur per week of meer en voor werkenden met een baan van 12 uur per week of meer, naar leeftijd, 2002-2005

\begin{tabular}{|l|c|c|}
\hline Leeftijd & $\begin{array}{c}\text { Werkzaam in baan van } \geq 12 \\
\text { uur per week } \\
\mathrm{N}(\mathrm{x} 1000)\end{array}$ & $\begin{array}{c}\text { Werkzaam in baan van } \\
\geq 1 \text { uur per week } \\
\mathrm{N}(\mathrm{x} 1000)\end{array}$ \\
\hline 15-24 jaar & 2,9 & 7,1 \\
25-34 jaar & 4,6 & 5,3 \\
35-44 jaar & 4,3 & 5,0 \\
$45-54$ jaar & 2,5 & 3,0 \\
$55-64$ jaar & 0,6 & 0,8 \\
Totaal & 14,9 & 21,1 \\
\hline
\end{tabular}

In deze notitie wordt op het hoogste digit niveau beroepenmobiliteit gemeten. Dit betekent dat de mobiliteit wordt gemeten door te bekijken of er tussen twee peilingen een verandering van beroepencode plaatsvindt op vijf digit niveau. Echter, de beroepenmobiliteit zou ook op een lager digit niveau kunnen worden gemeten, bijvoorbeeld op drie digit niveau. Tabel B3.5 laat zien in hoeverre beroepenmobiliteit dat op vijf digit niveau wordt vastgesteld in de periode 2002-2005 ook op drie digit niveau wordt gemeten. Indien deze aantallen zeer van elkaar verschillen kan er sprake zijn van 'ruis' bij het meten van beroepenmobiliteit op vijf digit niveau. Op vijf digit niveau wordt er 14,9 duizend keer een verandering van beroepencode gemeten; op drie digit niveau is dit 12,9 keer. Dit betekent dat voor het merendeel (87 procent) van de gevallen beroepenmobiliteit dat op vijf digit niveau wordt vastgesteld ook op drie digit niveau wordt gemeten. Dit geldt voor alle peilingen. Hiermee lijkt het er op dat er in de meeste gevallen geen sprake is van 'ruis' in de data als er op vijf digit niveau mobiliteit wordt 
gemeten. En het is daarbij helemaal niet onwaarschijnlijk dat een aantal personen van beroep wisselen waarbij alléén de laatste twee digits van de beroepencode veranderen.

Tabel B3.5: Verandering van beroepencode per peiling op vijf digit niveau en drie digit niveau, 15-64 jaar, 2002-2005

\begin{tabular}{|l|c|c|c|c|}
\hline \multicolumn{2}{|c|}{ Vijf digit niveau } \\
\\
\hline
\end{tabular}

* Hiervoor is het aantal personen met een verandering van beroepencode gedeeld door het aantal personen waarvan de beroepencode bekend is (peiling $2 \mathrm{t} / \mathrm{m}$ peiling 5 ; tabel 6 )

Hetzelfde geldt voor de relatie tussen de verandering van beroepencode en de verandering in werkkring. Ook dit kan op vijf digit niveau of op drie digit niveau worden weergegeven (zie verder in deze notitie). Opnieuw zijn de verschillen hier vrij gering. Van degenen die van werkkring zijn veranderd, is op vijf digit niveau 22 procent van beroep veranderd. Op drie digit niveau is dit percentage 20 procent.

Dit geldt in mindere mate voor de relatie tussen de verandering van de beroepencode en de vraag of iemand van beroep/functie is veranderd. Hier zijn de verschillen tussen vijf digit niveau en drie digit niveau wat groter (zie verder in deze notitie). Daarbij speelt wel mee dat de aantallen in deze laatste tabellen vrij klein zijn.

Tabel B3.6a: Verandering van werkkring en aantal/aandeel verandering van beroepencode (vijf digit), per peiling, 2003

\begin{tabular}{|l|l|c|c|c|c|}
\hline \multicolumn{5}{|c|}{$\begin{array}{c}\text { Geen verandering } \\
\text { beroepencode }\end{array}$} & \multicolumn{2}{c|}{$\begin{array}{c}\text { Verandering } \\
\text { beroepencode }\end{array}$} \\
\hline & & & & & \\
Zelfde werkkring peiling 1-peiling 2 & Ja & 42 & 99000 & 0,4 & 1 \\
& Nee & 1,5 & 76 & 0,5 & 24 \\
& & & & & \\
Zelfde werkkring peiling 2-peiling 3 & Ja & 38 & 99 & 0,4 & 1 \\
& Nee & 1,5 & 77 & 0,5 & 23 \\
Zelfde werkkring peiling 3-peiling 4 & Ja & 36 & 99 & 0,4 & 1 \\
& Nee & 1,4 & 78 & 0,4 & 22 \\
Zelfde werkkring peiling 4-peiling 5 & Ja & 36 & 99 & 0,3 & 1 \\
& Nee & 1,3 & 78 & 0,4 & 22 \\
\hline
\end{tabular}


Tabel B3.6b: Verandering van werkkring en aantal/aandeel verandering van beroepencode (drie digit), per peiling, 2003

\begin{tabular}{|c|c|c|c|c|c|}
\hline & & \multicolumn{2}{|c|}{$\begin{array}{l}\text { Geen verandering } \\
\text { beroepencode }\end{array}$} & \multicolumn{2}{|c|}{$\begin{array}{l}\text { Verandering } \\
\text { beroepencode }\end{array}$} \\
\hline & & $\mathrm{x} 1000$ & $\%$ & $\mathrm{x} 1000$ & $\%$ \\
\hline \multirow[t]{2}{*}{ Zelfde werkkring peiling 1-peiling 2} & $\mathrm{Ja}$ & 42 & 99 & 0,3 & 1 \\
\hline & Nee & 1,5 & 78 & 0,4 & 22 \\
\hline \multirow[t]{2}{*}{ Zelfde werkkring peiling 2-peiling 3} & $\mathrm{Ja}$ & 38 & 99 & 0,3 & 1 \\
\hline & Nee & 1,6 & 80 & 0,4 & 20 \\
\hline \multirow[t]{2}{*}{ Zelfde werkkring peiling 3-peiling 4} & $\mathrm{Ja}$ & 36 & 99 & 0,4 & 1 \\
\hline & Nee & 1,4 & 81 & 0,3 & 19 \\
\hline \multirow[t]{2}{*}{ Zelfde werkkring peiling 4-peiling 5} & $\mathrm{Ja}$ & 36 & 99 & 0,3 & 1 \\
\hline & Nee & 1,3 & 81 & 0,3 & 19 \\
\hline
\end{tabular}

Tabel B3.7a: Verandering van beroep/functie en aantal/aandeel verandering van beroepencode (vijf digit), per peiling, 2003

\begin{tabular}{|c|c|c|c|c|}
\hline \multirow[b]{2}{*}{ Zelfde beroep/functie als in vorige peiling? } & \multicolumn{2}{|c|}{$\begin{array}{l}\text { Geen verandering } \\
\text { beroepencode }\end{array}$} & \multicolumn{2}{|c|}{$\begin{array}{l}\text { Verandering } \\
\text { beroepencode }\end{array}$} \\
\hline & $\mathrm{x} 1000$ & $\%$ & $\mathrm{x} 1000$ & $\%$ \\
\hline Peiling 1-peiling 2: Nee & 0,2 & 45 & 0,3 & 55 \\
\hline Peiling 2-peiling 3: Nee & 0,3 & 49 & 0,3 & 51 \\
\hline Peiling 3-peiling 4: Nee & 0,2 & 41 & 0,3 & 59 \\
\hline Peiling 4-peiling 5: Nee & 0,3 & 49 & 0,3 & 51 \\
\hline
\end{tabular}


Tabel B3.7b: Verandering van beroep/functie en aantal/aandeel verandering van beroepencode (drie digit), per peiling, 2003

\begin{tabular}{|c|c|c|c|c|}
\hline \multirow[b]{2}{*}{ Zelfde beroep/functie als in vorige peiling? } & \multicolumn{2}{|c|}{$\begin{array}{l}\text { Geen verandering } \\
\text { beroepencode }\end{array}$} & \multicolumn{2}{|c|}{$\begin{array}{l}\text { Verandering } \\
\text { beroepencode }\end{array}$} \\
\hline & x 1000 & $\%$ & $\mathrm{x} 1000$ & $\%$ \\
\hline Peiling 1-peiling 2: Nee & 0,3 & 56 & 0,2 & 44 \\
\hline Peiling 2-peiling 3: Nee & 0,3 & 55 & 0,3 & 45 \\
\hline Peiling 3-peiling 4: Nee & 0,3 & 49 & 0,3 & 51 \\
\hline Peiling 4-peiling 5: Nee & 0,3 & 57 & 0,2 & 43 \\
\hline
\end{tabular}

* Voor personen waarvan de werkkring niet is veranderd 


\section{Bijlage 4: Beroepenmobiliteit op 3 digit niveau, 2002-2005}

Tabel B4.1 Beroepenmobiliteit naar richting (hetzelfde beroep, nieuw beroep, werkloosheid en non-participatie) (ongewogen)

\begin{tabular}{|c|c|c|c|c|c|c|c|}
\hline Beroep & & $\begin{array}{l}\text { Werkzaam } \\
\text { in zelfde } \\
\text { beroep }\end{array}$ & $\begin{array}{l}\text { Mobiliteit } \\
\text { richting } \\
\text { werkloosheid }\end{array}$ & $\begin{array}{l}\text { Mobiliteit } \\
\text { richting non- } \\
\text { participatie }\end{array}$ & Mobiliteit richting beroep 1 & Mobiliteit richting beroep 2 & Mobiliteit richting beroep 3 \\
\hline 1 & Leraar basisonderwijs & 97,6 & 0,3 & 1,2 & Onderwijskundig medewerkers & Leidinggevenden & Boekhouders en secretaresses \\
\hline 2 & $\begin{array}{l}\text { Docenten exacte, medische en } \\
\text { verzorgende vakken ( } 2 \text { e graads) }\end{array}$ & 96,2 & 0,6 & 1,5 & Docenten talen en expressie & Docenten exact, medisch $1 \mathrm{de}$ & Leraar basisonderwijs \\
\hline 3 & $\begin{array}{l}\text { Docenten exacte, medische en } \\
\text { verzorgende vakken (1e graads) }\end{array}$ & 96,2 & 0,4 & 1,6 & Docenten exact, medisch $2 \mathrm{de}$ & Leraar basisonderwijs & Natuurwetenschappers \\
\hline 4 & $\begin{array}{l}\text { Docenten landbouw en techniek (2e } \\
\text { graads) }\end{array}$ & 95,7 & 0,3 & 1,7 & Docenten landbouw en techniek le & Leraar basisonderwijs & Managers \\
\hline 5 & $\begin{array}{l}\text { Docenten landbouw en techniek (1e } \\
\text { graads) }\end{array}$ & 94,7 & 1,0 & 2,0 & Onderwijskundigen en pedagogen & Docenten landbouw en techniek $2^{\text {de }}$ & Hulpkrachten horeca en verzorging \\
\hline 6 & $\begin{array}{l}\text { Docenten economisch-administratieve } \\
\text { vakken (2e graads) }\end{array}$ & 96,4 & 0,5 & 1,3 & Leraar basisonderwijs & Managers & Docenten exact, medisch $2 \mathrm{de}$ \\
\hline 7 & $\begin{array}{l}\text { Docenten economisch-administratieve } \\
\text { vakken (1e graads) }\end{array}$ & 95,5 & 0,5 & 1,4 & Managers & Docenten economisch adm. 2 de & Bedrijfshoofden metaalbewerking \\
\hline 8 & Docenten talen en expressie & 95,7 & 0,4 & 2,2 & Kunstenaars & Leraar basisonderwijs & Docenten letteren 1e \\
\hline
\end{tabular}




\begin{tabular}{|c|c|c|c|c|c|c|c|}
\hline 99 & Docenten letteren (1e graads) & 95,8 & 0,3 & 2,2 & Kunstenaars & Managers & Docenten talen en expressie \\
\hline 10 & Docenten sociale vakken (2e graads) & 95,9 & 0,1 & 2,0 & Sportinstructeurs & Docenten zonder specialisatie $2 \mathrm{de}$ & Docenten sociale vakken $1 \mathrm{de}$ \\
\hline 11 & Docenten sociale vakken (1e graads) & 95,1 & 0,5 & 1,4 & Managers & Leraar basisonderwijs & Hoofden sociaal cultureel en $\mathrm{p} \& \mathrm{o}$ \\
\hline 12 & Docenten $2 \mathrm{e}$ graads zonder specialisatie & 96,8 & 0,2 & 1,9 & Docent le graads zonder specialisatie & Docenten exact, medisch $2 \mathrm{de}$ & Leidinggevenden \\
\hline 13 & Docent le graads zonder specialisatie & 97,0 & 0,0 & 1,3 & Docenten zonder specialisatie $2 \mathrm{de}$ & Docenten sociale vakken $1 \mathrm{de}$ & Bedrijfshoofden \\
\hline 14 & Onderwijskundig medewerkers & 93,2 & 0,4 & 2,0 & Leraar basisonderwijs & $\begin{array}{l}\text { Medewerkers sociaal-cultureel en } \\
\text { personeel }\end{array}$ & Onderwijskundigen en pedagogen \\
\hline 15 & Onderwijskundigen en pedagogen & 95,5 & 0,6 & 1,1 & Managers & $\begin{array}{l}\text { Medewerkers sociaal-cultureel en } \\
\text { personeel }\end{array}$ & Bedrijfshoofden \\
\hline 16 & Rij-instructeurs & 97,2 & 0,7 & 1,2 & Docenten economisch adm. $2 \mathrm{de}$ & Grafische vakkrachten & Aspirant politie, soldaat beveiliging \\
\hline 17 & Zweminstructeurs & 94,1 & 1,4 & 2,3 & Chauffeurs & Interieurverzorgers & Verzorgend personeel \\
\hline 18 & Sportinstructeurs & 89,9 & 1,0 & 5,5 & Docenten sociale vakken $2 \mathrm{de}$ & Verplegenden en doktersassistenten & Leraar basisonderwijs \\
\hline 19 & Tolken, vertalers en schrijvers & 93,5 & 1,1 & 2,9 & Commercieel medewerkers & Bedrijfshoofden & Kunstenaars \\
\hline 20 & Bibliotheekassistenten & 94,1 & 0,9 & 2,5 & Boekhouders en secretaresses & Receptionisten en administratief & Commercieel employés \\
\hline 21 & Bibliothecarissen & 97,4 & 0,1 & 0,4 & Bibliotheekassistenten & Taalkundigen & Juridisch bestuurlijke medewerker \\
\hline 22 & Grafisch ontwerpers & 95,5 & 0,9 & 2,0 & Grafisch productiepersoneel & Commercieel employés & Kunstenaars \\
\hline 23 & Kunstenaars & 94,3 & 0,9 & 2,2 & Docenten talen en expressie & Verkopers & Docenten letteren 1e \\
\hline 24 & Geestelijk verzorgers & 96,0 & 0,7 & 0,7 & $\begin{array}{l}\text { Sociaal-wetenschappelijk } \\
\text { medewerkers }\end{array}$ & Programmeurs & Activiteitenbegeleiders \\
\hline 25 & Geestelijken & 98,6 & 0,0 & 1,0 & Geestelijk verzorgers & Activiteitenbegeleiders & $\begin{array}{l}\text { Sociaal-wetenschappelijk } \\
\text { medewerkers }\end{array}$ \\
\hline
\end{tabular}




\begin{tabular}{|c|c|c|c|c|c|c|c|}
\hline 26 & Journalisten & 95,3 & 0,6 & 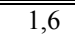 & Kunstenaars & Commercieel medewerkers & Taalkundigen \\
\hline 27 & Taalkundigen & 95,0 & 0,6 & 1,3 & Organisatie-adviseurs & Commercieel employés & Journalisten \\
\hline 28 & Agrarische hulparbeiders & 75,5 & 4,3 & 16,1 & Agrarische hulparbeiders & Verkopers & Agrarische bedrijfshoofden \\
\hline 29 & Agrarische arbeiders & 91,1 & 1,0 & 4,9 & Agrarische bedrijfshoofden & Laders en lossers & Chauffeurs \\
\hline 30 & Agrarische vakkrachten & 96,2 & 0,8 & 1,0 & Verkopers & Agrarische bedrijfshoofden & Agrarische hulparbeiders \\
\hline 31 & $\begin{array}{l}\text { Milieuhygiënisten en agrarisch } \\
\text { vertegenwoordigers }\end{array}$ & 95,9 & 0,3 & 1,3 & Commercieel employés & Agrarische bedrijfshoofden & Commercieel medewerkers \\
\hline 32 & Landbouwkundigen & 94,6 & 1,8 & 1,0 & Weg en waterbouwkundigen & Commercieel medewerkers & $\begin{array}{l}\text { Sociaal-wetenschappelijk } \\
\text { onderzoekers }\end{array}$ \\
\hline 33 & Landbouwmachinebestuurders en vissers & 94,6 & 1,0 & 1,7 & Agrarische bedrijfshoofden & Productiemedewerkers & $\begin{array}{l}\text { Weg- en waterbouwkundige } \\
\text { vakkachten }\end{array}$ \\
\hline 34 & Agrarische bedrijfshoofden & 97,7 & 0,1 & 1,0 & Agrarische hulparbeiders & Winkeliers & Productiemedewerkers \\
\hline 35 & Productiemedewerkers & 91,5 & 1,6 & 3,3 & Laders en lossers & Chauffeurs & Kantoorhulpen \\
\hline 36 & Laboratorium-assistenten & 98,4 & 0,0 & 0,9 & Agrarische bedrijfshoofden & Medisch analisten & Productiemedewerkers \\
\hline 37 & Laboranten & 95,6 & 0,3 & 1,6 & Technisch analisten & Verkopers & Mechanische operators \\
\hline 38 & Technisch analisten & 96,1 & 0,7 & 0,6 & $\begin{array}{l}\text { Sociaal-wetenschappelijk } \\
\text { medewerkers }\end{array}$ & Laboranten & Medisch analisten \\
\hline 39 & Natuurwetenschappers & 96,3 & 0,8 & 0,7 & $\begin{array}{l}\text { Sociaal-wetenschappelijk } \\
\text { onderzoekers }\end{array}$ & Commercieel employés & Weg- en waterbouwkundigen \\
\hline 40 & Conciërges & 95,9 & 0,4 & 1,9 & Interieurverzorgers & Leraar basisonderwijs & Commercieel employés \\
\hline 41 & Hoofden technische dienst & 96,7 & 0,4 & 0,7 & Monteurs & Boekhouders en secretaresses & Aannemers en installateurs \\
\hline
\end{tabular}




\begin{tabular}{|c|c|c|c|c|c|c|c|}
\hline 42 & Werktuigbouwkundigen & 95,7 & 0,6 & 0,6 & Werktuigbouwkundig ontwerpers & Hoofden technische dienst & Productiemedewerkers \\
\hline 43 & $\begin{array}{l}\text { Bouwvakkers } \\
\text { Aannemers en installateurs }\end{array}$ & 95,8 & 1,1 & 1,4 & $\begin{array}{l}\text { Aannemers en installateurs } \\
\text { Bouwvakkers }\end{array}$ & $\begin{array}{l}\text { Laders en lossers } \\
\text { Architecten en bouwkundig }\end{array}$ & $\begin{array}{l}\text { Chauffeurs } \\
\text { Monteurs }\end{array}$ \\
\hline 44 & & 97,1 & 0,4 & 0,8 & & projectleiders & \\
\hline 45 & $\begin{array}{l}\text { Architecten en bouwkundig } \\
\text { projectleiders }\end{array}$ & 96,2 & 0,4 & 1,1 & Aannemers en installateurs & Weg- en waterbouwkundigen & Boekhouders en secretaresses \\
\hline 46 & Weg- en waterbouwkundigen & 96,0 & 0,8 & 1,0 & Commercieel medewerkers & $\begin{array}{l}\text { Architecten en bouwkundig } \\
\text { projectleiders }\end{array}$ & Aannemers en installateurs \\
\hline 47 & Weg- en waterbouwkundige arbeiders & 95,2 & 1,2 & 1,4 & $\begin{array}{l}\text { Weg- en waterbouwkundige } \\
\text { vakkrachten }\end{array}$ & Productiemedewerkers & Monteurs \\
\hline 48 & Weg- en waterbouwkundige vakkrachten & 96,8 & 0,6 & 0,9 & Monteurs & Boekhouders en secretaresses & $\begin{array}{l}\text { Weg- en waterbouwkundig } \\
\text { ontwerpers en projectleiders }\end{array}$ \\
\hline 49 & $\begin{array}{l}\text { Weg- en waterbouwkundig ontwerpers } \\
\text { en projectleiders }\end{array}$ & 96,7 & 0,4 & 0,9 & Weg- en waterbouwkundigen & Managers & Leidinggevenden \\
\hline 50 & Metaalarbeiders & 95,2 & 1,0 & 1,3 & Bankwerkers en lassers & Monteurs & Laders en lossers \\
\hline 51 & Bankwerkers en lassers & 95,4 & 0,9 & 1,4 & Metaalarbeiders & Monteurs & Aannemers en installateurs \\
\hline 52 & Bedrijfshoofden metaalbewerking & 92,6 & 1,0 & 2,6 & Commercieel medewerkers & Monteurs & Leraar basisonderwijs \\
\hline 53 & Assembleurs & 94,3 & 1,0 & 1,9 & Monteurs & Metaalarbeiders & Laders en lossers \\
\hline 54 & Monteurs & 99,9 & 0,5 & 0,8 & Chauffeurs & Aannemers en installateurs & Elektromonteurs \\
\hline 55 & $\begin{array}{l}\text { Werktuigbouwkundig ontwerpers en } \\
\text { hoofden technische dienst }\end{array}$ & 95,3 & 0,6 & 1,0 & Monteurs & $\begin{array}{l}\text { Architecten en bouwkundig } \\
\text { projectleiders }\end{array}$ & Systeemanalisten \\
\hline
\end{tabular}




\begin{tabular}{|c|c|c|c|c|c|c|c|}
\hline 256 & Elektronicamonteurs & 94,4 & 1,3 & 0,9 & Programmeurs & Monteurs & Systeemanalisten \\
\hline 57 & $\begin{array}{l}\text { Monteurs en controleurs } \\
\text { elektrotechnische producten }\end{array}$ & 93,0 & 1,3 & 1,7 & Elektromonteurs & Monteurs & Metaalarbeiders \\
\hline 58 & Elektromonteurs & 96,2 & 0,6 & 1,1 & Monteurs & Monteurs en controleurs elektro & Aannemers en installateurs \\
\hline 59 & $\begin{array}{l}\text { Elektrotechnisch ontwerpers en } \\
\text { bedrijfshoofden }\end{array}$ & 95,5 & 0,6 & 0,9 & Managers & $\begin{array}{l}\text { Architecten en bouwkundig } \\
\text { projectleiders }\end{array}$ & Organisatie-adviseurs \\
\hline 60 & Elektrotechnici & 94,4 & 0,8 & 0,6 & $\begin{array}{l}\text { Elektrotechnisch ontwerpers en } \\
\text { bedrijfshoofden }\end{array}$ & Elektromonteurs & Managers \\
\hline 61 & Grafisch productiepersoneel & 96,1 & 1,1 & 1,0 & Receptionisten en administratief & Grafische ontwerpers & Grafische vakkrachten \\
\hline 62 & Grafische vakkrachten & 96,1 & 0,6 & 1,2 & Grafisch productiepersoneel & Receptionisten en administratief & Bedrijfshoofden \\
\hline 63 & Mechanisch operators & 94,0 & 1,3 & 1,7 & Verkopers & Chauffeurs & Aspirant politie, soldaat beveiliging \\
\hline 65 & Procestechnologen & 95,9 & 0,3 & 0,8 & Materiaalkundigen & Boekhouders en secretaresses & Mechanische operators \\
\hline 66 & Materiaalkundigen & 94,8 & 1,0 & 0,7 & Commercieel medewerkers & Commercieel employés & Productiemedewerkers \\
\hline 67 & Confectie-arbeiders & 94,9 & 1,2 & 2,5 & Verkopers & Kantoorhulpen & Receptionisten en administratief \\
\hline 68 & Schoen- en kleermakers & 98,0 & 0,0 & 0,9 & Confectie-arbeiders & Winkeliers & Commercieel medewerkers \\
\hline 69 & Laders en lossers & 90,0 & 1,9 & 3,8 & Chauffeurs & Boekhouders en secretaresses & Kantoorhulpen \\
\hline 70 & Chauffeurs & 95,7 & 0,7 & 1,8 & Laders en lossers & Monteurs & Bouwvakkers \\
\hline 71 & Schippers en conducteurs & 95,9 & 0,6 & 1,5 & Chauffeurs & Monteurs & $\begin{array}{l}\text { Vliegers, scheepskap en leiding } \\
\text { transport }\end{array}$ \\
\hline 72 & $\begin{array}{l}\text { Vliegers, scheepskapiteins en } \\
\text { leidinggevenden transport }\end{array}$ & 96,8 & 0,4 & 0,8 & Schippers en conducteurs & Managers & Chauffeurs \\
\hline
\end{tabular}




\begin{tabular}{|c|c|c|c|c|c|c|c|}
\hline$\overline{773}$ & Stewards & 94,5 & 0,8 & 2,5 & Receptionisten en administratief & Commercieel employés & Verkopers \\
\hline 74 & $\begin{array}{l}\text { Verpleeghulpen en leerling- } \\
\text { verpleegkundigen }\end{array}$ & 91,7 & 0,8 & 2,8 & Ziekenverzorgenden & Verplegenden en doktersassistenten & Verzorgend personeel \\
\hline 75 & Verplegenden en doktersassistenten & 96,7 & 0,3 & 1,3 & Therapeuten & Managers & Ziekenverzorgenden \\
\hline 76 & Therapeuten en verpleegkundigen & 97,0 & 0,2 & 1,2 & Managers & Verplegenden en doktersassistenten & $\begin{array}{l}\text { Medewerkers sociaal-cultureel en } \\
\text { personeel }\end{array}$ \\
\hline 77 & Artsen & 97,9 & 0,4 & 0,7 & Therapeuten & Managers & Afdelingshoofden zorginstelling \\
\hline 78 & $\begin{array}{l}\text { Apothekersassistenten en medisch } \\
\text { laboranten }\end{array}$ & 97,5 & 0,4 & 1,0 & Medisch analisten & Monteurs & Verplegenden en doktersassistenten \\
\hline 79 & Medisch analisten & 98,1 & 0,2 & 0,7 & Apothekersassistenten & Artsen & Boekhouders en secretaresses \\
\hline 80 & Apothekers & 97,8 & 0,3 & 0,4 & Commercieel medewerkers & Medisch analisten & Apothekersassistenten \\
\hline 81 & Afdelingshoofden zorginstelling & 94,5 & 0,3 & 0,9 & Managers & Verzorgend personeel & Artsen \\
\hline 82 & Kantoorhulpen, inpakkers en colporteurs & 84,0 & 2,9 & 7,9 & Laders en lossers & Interieurverzorgers & Receptionisten en administratief \\
\hline 83 & $\begin{array}{l}\text { Ondersteunende administratieve } \\
\text { hulpkrachten }\end{array}$ & 84,2 & 2,9 & 6,6 & Receptionisten en administratief & Boekhouders en secretaresses & Commercieel employés \\
\hline 84 & Bedrijfshoofden & 94,8 & 0,4 & 1,5 & Commercieel employés & Boekhouders en secretaresses & Commercieel medewerkers \\
\hline 85 & Economen & 94,5 & 0,6 & 1,3 & Commercieel medewerkers & $\begin{array}{l}\text { Sociaal-wetenschappelijk } \\
\text { onderzoekers }\end{array}$ & Juristen \\
\hline 86 & Productieplanners & 95,0 & 0,7 & 1,0 & Commercieel employés & Boekhouders en secretaresses & Organisatie-adviseurs \\
\hline 87 & Organisatie-adviseurs & 93,5 & 0,9 & 0,9 & Commercieel medewerkers & Boekhouders en secretaresses & $\begin{array}{l}\text { Medewerkers sociaal-cultureel en } \\
\text { personeel }\end{array}$ \\
\hline
\end{tabular}




\begin{tabular}{|c|c|c|c|c|c|c|c|}
\hline 88 & $\begin{array}{l}\text { Organisatiedeskundigen } \\
\text { Receptionisten en administratieve } \\
\text { employés }\end{array}$ & 95,3 & 0,6 & 0,9 & $\begin{array}{l}\text { Commercieel medewerkers } \\
\text { Boekhouders en secretaresses }\end{array}$ & $\begin{array}{l}\text { Managers } \\
\text { Commercieel employés }\end{array}$ & $\begin{array}{l}\text { Assistent accountants } \\
\text { Verkopers }\end{array}$ \\
\hline 90 & Boekhouders en secretaresses & 95,8 & 0,8 & 1,3 & Receptionisten en administratief & Commercieel employés & Assistent accountants \\
\hline 91 & Assistent accountants & 96,1 & 0,6 & 0,7 & Boekhouders en secretaresses & Accountants & Commercieel medewerkers \\
\hline 92 & Accountants & 96,8 & 0,2 & 0,5 & Assistant accountants & Commercieel medewerkers & Boekhouders en secretaresses \\
\hline 93 & Verzekeringsagenten & 94,2 & 0,7 & 2,0 & Boekhouders en secretaresses & Commercieel employés & Receptionisten en administratief \\
\hline 94 & Commercieel employés & 94,8 & 1,0 & 1,3 & Commercieel medewerkers & Boekhouders en secretaresses & Receptionisten en administratief \\
\hline 95 & Commercieel medewerkers & 96,0 & 0,6 & 0,8 & Commercieel employés & Boekhouders en secretaresses & Managers \\
\hline 96 & Technisch-commercieel employés & 95,9 & 0,5 & 0,9 & Commercieel employés & Productieplanners & Aannemers en installateurs \\
\hline 97 & Technisch-bedrijfskundig medewerkers & 93,7 & 1,0 & 1,2 & Commercieel employés & Commercieel medewerkers & Activiteitenbegeleiders \\
\hline 98 & Juridisch en fiscaal medewerkers & 97,4 & 0,3 & 0,8 & Boekhouders en secretaresses & Juristen & Receptionisten en administratief \\
\hline 99 & Juridisch, bestuurlijk medewerkers & 94,8 & 0,4 & 1,2 & Leidinggevenden & $\begin{array}{l}\text { Sociaal-wetenschappelijk } \\
\text { medewerkers }\end{array}$ & Boekhouders en secretaresses \\
\hline 100 & Juristen & 97,0 & 0,4 & 1,0 & Managers & $\begin{array}{l}\text { Sociaal-wetenschappelijk } \\
\text { onderzoekers }\end{array}$ & Boekhouders en secretaresses \\
\hline 101 & Administratieve transportemployés & 95,5 & 0,8 & 1,0 & Commercieel employés & Boekhouders en secretaresses & Organisatie-adviseurs \\
\hline 102 & Leidinggevenden & 96,5 & 0,3 & 0,8 & Managers & Leraar basisonderwijs & Commercieel medewerkers \\
\hline 103 & Managers & 95,6 & 0,4 & 1,0 & Leidinggevenden & Commercieel medewerkers & Organisatiedeskundigen \\
\hline 104 & Medisch secretaresses & 96,9 & 0,6 & 1,0 & Boekhouders en secretaresses & Receptionisten en administratief & Productieplanners \\
\hline 105 & Programmeurs & 95,0 & 0,9 & 1,2 & Systeemanalisten & Receptionisten en administratief & Commercieel employés \\
\hline
\end{tabular}




\begin{tabular}{|c|c|c|c|c|c|c|c|}
\hline 106 & Systeemanalisten & 95,6 & 0,6 & 0,5 & Informatici & Programmeurs & Commercieel employés \\
\hline 107 & Informatici & 94,9 & 0,7 & 0,3 & Systeemanalisten & Commercieel employés & Managers \\
\hline 108 & Technisch systeemanalisten & 95,5 & 0,3 & 1,5 & Systeemanalisten & $\begin{array}{l}\text { Architecten en bouwkundig } \\
\text { projectleiders }\end{array}$ & Informatici \\
\hline 109 & $\begin{array}{l}\text { Activiteitenbegeleiders en medewerkers } \\
\text { arbeidsbemiddeling }\end{array}$ & 94,0 & 0,7 & 1,7 & $\begin{array}{l}\text { Medewerkers sociaal-cultureel en } \\
\text { personeel }\end{array}$ & Verzorgend personeel & Boekhouders en secretaresses \\
\hline 110 & $\begin{array}{l}\text { Medewerkers sociaal-cultureel werk en } \\
\text { personeel en arbeid }\end{array}$ & 95,3 & 0,8 & 0,9 & Boekhouders en secretaresses & Activiteitenbegeleiders & Managers \\
\hline 111 & $\begin{array}{l}\text { Hoofden sociaal-cultureel werk en } \\
\text { personeel en arbeid }\end{array}$ & 95,9 & 0,4 & 1,1 & Activiteitenbegeleiders & $\begin{array}{l}\text { Medewerkers sociaal-cultureel en } \\
\text { personeel }\end{array}$ & Organisatiedeskundigen \\
\hline 112 & Sociaal-wetenschappelijk medewerkers & 96,5 & 0,0 & 1,0 & $\begin{array}{l}\text { Medewerkers sociaal-cultureel en } \\
\text { personeel }\end{array}$ & $\begin{array}{l}\text { Sociaal-wetenschappelijke } \\
\text { onderzoekers }\end{array}$ & Leidinggevenden \\
\hline 113 & Sociaal-wetenschappelijk onderzoekers & 95,6 & 0,4 & 0,8 & Managers & Juristen & $\begin{array}{l}\text { Medewerkers sociaal-cultureel en } \\
\text { personeel }\end{array}$ \\
\hline 114 & Vakkenvullers & 80,1 & 1,3 & 12,7 & Verkopers & Hulpkrachten horeca en verzorging & Interieurverzorgers \\
\hline 115 & Interieurverzorgers & 88,5 & 1,4 & 6,6 & Hulpkrachten horeca en verzorging & Verkopers & Receptionisten en administratief \\
\hline 116 & Verkopers & 91,2 & 1,2 & 4,5 & Interieurverzorgers & Receptionisten en administratief & Hulpkrachten horeca en verzorging \\
\hline 117 & Winkeliers & 96,4 & 0,6 & 1,1 & Verkopers & Commercieel employés & Receptionisten en administratief \\
\hline 118 & Hulpkrachten horeca en verzorging & 88,5 & 1,1 & 6,7 & Verzorgend personeel & Interieurverzorgers & Verkopers \\
\hline 119 & Ziekenverzorgenden & 96,1 & 0,2 & 1,6 & Verplegenden en dokterassistenten & Verzorgend personeel & Activiteitenbegeleiders \\
\hline 120 & Verzorgend personeel & 94,9 & 0,6 & 2,1 & Hulpkrachten horeca en verzorging & Ziekenverzorgenden & Activiteitenbegeleiders \\
\hline
\end{tabular}




\begin{tabular}{|c|c|c|c|c|c|c|c|}
\hline 121 & Café- en snackbarhouders & 95,9 & 0,3 & 1,8 & Bedrijfshoofden horeca & Interieurverzorgers & Hulpkrachten horeca en verzorging \\
\hline 122 & Bedrijfshoofden horeca & 95,5 & 0,7 & 1,5 & Hulpkrachten horeca en verzorging & Verzorgend personeel & Verkopers \\
\hline 124 & $\begin{array}{l}\text { Aspirant politieagenten, soldaten en } \\
\text { beveiligingshulpkrachten }\end{array}$ & 94,2 & 1,2 & 1,5 & Politieagenten, onder officieren e.d. & Receptionisten en administratief & Chauffeurs \\
\hline 125 & $\begin{array}{l}\text { Politieagenten, onderofficieren en } \\
\text { beveiligingsemployés }\end{array}$ & 97,3 & 0,1 & 0,7 & Aspirant politieagenten soldaten e.d. & Managers & Politie-inspecteurs en officieren \\
\hline 126 & Politie-inspecteurs en officieren & 96,0 & 0,1 & 1,7 & Politieagenten, onder officieren e.d. & Aspirant politieagenten soldaten e.d. & $\begin{array}{l}\text { Medewerkers sociaal-cultureel en } \\
\text { personeel }\end{array}$ \\
\hline \multirow[t]{3}{*}{127} & Brandweerlieden & 95,9 & 0,8 & 0,7 & $\begin{array}{l}\text { Architecten en bouwkundig } \\
\text { projectleiders }\end{array}$ & Commercieel employés & Monteurs \\
\hline & Werkloosheid & 46,8 & & 28,9 & Boekhouders en secretaresses & Verkopers & Receptionisten en administratief \\
\hline & Non-participatie & 93,2 & 3,1 & & Verkopers & Hulpkrachten horeca en verzorging & Interieurverzorgers \\
\hline
\end{tabular}


Tabel B4.2 Beroepenmobiliteit naar richting (zelfde beroep, werkoosheid en non-participatie), mannen (ongewogen)

\begin{tabular}{|c|c|c|c|c|}
\hline Beroep & & $\begin{array}{c}\text { Werkzaam } \\
\text { in zelfde } \\
\text { beroep }\end{array}$ & $\begin{array}{c}\text { Mobiliteit } \\
\text { richting } \\
\text { werkloosheid }\end{array}$ & $\begin{array}{c}\text { Mobiliteit } \\
\text { richting non- } \\
\text { participatie }\end{array}$ \\
\hline 1 & Leraar basisonderwijs & 98,0 & 0,2 & 0,7 \\
\hline 2 & $\begin{array}{l}\text { Docenten exacte, medische en } \\
\text { verzorgende vakken ( } 2 \text { e graads) }\end{array}$ & 96,9 & 0,6 & 0,9 \\
\hline 3 & $\begin{array}{l}\text { Docenten exacte, medische en } \\
\text { verzorgende vakken (1e graads) }\end{array}$ & 96,4 & 0,3 & 1,6 \\
\hline 4 & $\begin{array}{l}\text { Docenten landbouw en techniek ( } 2 \mathrm{e} \\
\text { graads) }\end{array}$ & 95,8 & 0,3 & 1,4 \\
\hline 5 & $\begin{array}{l}\text { Docenten landbouw en techniek (1e } \\
\text { graads) }\end{array}$ & 95,0 & 1,4 & 0,9 \\
\hline 6 & $\begin{array}{l}\text { Docenten economisch-administratieve } \\
\text { vakken ( } 2 \text { e graads) }\end{array}$ & 97,0 & 0,4 & 0,7 \\
\hline 7 & $\begin{array}{l}\text { Docenten economisch-administratieve } \\
\text { vakken (1e graads) }\end{array}$ & 95,6 & 0,6 & 1,5 \\
\hline 8 & Docenten talen en expressie & 96,8 & 0,3 & 1,4 \\
\hline 9 & Docenten letteren (1e graads) & 95,7 & 0,5 & 1,9 \\
\hline 10 & Docenten sociale vakken (2e graads) & 97,3 & 0,0 & 1,1 \\
\hline 11 & Docenten sociale vakken (1e graads) & 96,4 & 0,4 & 1,2 \\
\hline 12 & Docenten 2e graads zonder specialisatie & 97,5 & 0,0 & 1,3 \\
\hline 13 & Docent 1e graads zonder specialisatie & 97,3 & 0,0 & 1,6 \\
\hline 14 & Onderwijskundig medewerkers & 94,2 & 0,2 & 1,4 \\
\hline 15 & Onderwijskundigen en pedagogen & 94,8 & 0,6 & 0,7 \\
\hline 16 & Rij-instructeurs & 97,3 & 0,7 & 1,0 \\
\hline 17 & Zweminstructeurs & 91,8 & 1,9 & 2,4 \\
\hline 18 & Sportinstructeurs & 89,4 & 0,7 & 4,2 \\
\hline 19 & Tolken, vertalers en schrijvers & 93,0 & 1,9 & 2,1 \\
\hline 20 & Bibliotheekassistenten & 93,4 & 0,9 & 2,6 \\
\hline 21 & Bibliothecarissen & 94,5 & 0,5 & 0,0 \\
\hline 22 & Grafisch ontwerpers & 96,2 & 0,9 & 1,7 \\
\hline 23 & Kunstenaars & 95,0 & 0,9 & 1,5 \\
\hline 24 & Geestelijk verzorgers & 96,4 & 0,0 & 0,7 \\
\hline 25 & Geestelijken & 98,5 & 0,0 & 1,3 \\
\hline 26 & Journalisten & 95,7 & 0,5 & 1,4 \\
\hline 27 & Taalkundigen & 96,6 & 0,3 & 0,5 \\
\hline 28 & Agrarische hulparbeiders & 64,8 & 6,1 & 21,7 \\
\hline
\end{tabular}




\begin{tabular}{|c|c|c|c|c|}
\hline 29 & Agrarische arbeiders & 92,3 & 0,8 & 4,1 \\
\hline 30 & Agrarische vakkrachten & 97,1 & 0,5 & 0,5 \\
\hline 31 & $\begin{array}{l}\text { Milieuhygiënisten en agrarisch } \\
\text { vertegenwoordigers }\end{array}$ & 96,1 & 0,3 & 1,2 \\
\hline 32 & Landbouwkundigen & 94,1 & 2,0 & 1,2 \\
\hline 33 & Landbouwmachinebestuurders en vissers & 94,7 & 0,9 & 1,7 \\
\hline 34 & Agrarische bedrijfshoofden & 98,1 & 0,1 & 0,7 \\
\hline 35 & Productiemedewerkers & 91,9 & 1,5 & 3,0 \\
\hline 36 & Laboratorium-assistenten & 96,9 & 0,0 & 1,6 \\
\hline 37 & Laboranten & 94,7 & 0,4 & 1,6 \\
\hline 38 & Technisch analisten & 96,3 & 0,3 & 0,6 \\
\hline 39 & Natuurwetenschappers & 96,7 & 0,8 & 0,8 \\
\hline 40 & Conciërges & 96,3 & 0,4 & 1,7 \\
\hline 41 & Hoofden technische dienst & 96,6 & 0,4 & 0,7 \\
\hline 42 & Werktuigbouwkundigen & 96,0 & 0,7 & 0,4 \\
\hline 43 & Bouwvakkers & 95,8 & 1,1 & 1,4 \\
\hline 44 & Aannemers en installateurs & 97,2 & 0,4 & 0,8 \\
\hline 45 & $\begin{array}{l}\text { Architecten en bouwkundig } \\
\text { projectleiders }\end{array}$ & 96,3 & 0,4 & 0,9 \\
\hline 46 & Weg- en waterbouwkundigen & 96,3 & 0,5 & 1,0 \\
\hline 47 & Weg- en waterbouwkundige arbeiders & 95,2 & 1,2 & 1,4 \\
\hline 48 & Weg- en waterbouwkundige vakkrachten & 96,7 & 0,6 & 0,9 \\
\hline 49 & $\begin{array}{l}\text { Weg- en waterbouwkundig ontwerpers } \\
\text { en projectleiders }\end{array}$ & 96,8 & 0,3 & 0,9 \\
\hline 50 & Metaalarbeiders & 95,4 & 0,9 & 1,2 \\
\hline 51 & Bankwerkers en lassers & 95,6 & 0,8 & 1,2 \\
\hline 52 & Bedrijfshoofden metaalbewerking & 93,1 & 1,2 & 2,4 \\
\hline 53 & Assembleurs & 94,5 & 0,9 & 1,8 \\
\hline 54 & Monteurs & 96,9 & 0,5 & 0,8 \\
\hline 55 & $\begin{array}{l}\text { Werktuigbouwkundig ontwerpers en } \\
\text { hoofden technische dienst }\end{array}$ & 95,5 & 0,5 & 1,0 \\
\hline 56 & Elektronicamonteurs & 94,7 & 1,2 & 0,7 \\
\hline 57 & $\begin{array}{l}\text { Monteurs en controleurs } \\
\text { elektrotechnische producten }\end{array}$ & 93,8 & 1,1 & 1,2 \\
\hline 58 & Elektromonteurs & 96,2 & 0,6 & 1,1 \\
\hline
\end{tabular}




\begin{tabular}{|c|c|c|c|c|}
\hline 259 & $\begin{array}{l}\text { Elektrotechnisch ontwerpers en } \\
\text { bedrijfshoofden }\end{array}$ & 95,3 & $\overline{0,6}$ & 0,9 \\
\hline 60 & Elektrotechnici & 94,3 & 0,7 & 0,7 \\
\hline 61 & Grafisch productiepersoneel & 96,3 & 1,1 & 0,8 \\
\hline 62 & Grafische vakkrachten & 96,5 & 0,5 & 1,1 \\
\hline 63 & Mechanisch operators & 94,5 & 1,0 & 1,4 \\
\hline 65 & Procestechnologen & 96,0 & 0,4 & 0,8 \\
\hline 66 & Materiaalkundigen & 95,0 & 0,6 & 0,7 \\
\hline 67 & Confectie-arbeiders & 95,5 & 1,2 & 1,8 \\
\hline 68 & Schoen- en kleermakers & 98,7 & 0,0 & 0,4 \\
\hline 69 & Laders en lossers & 90,0 & 1,8 & 3,7 \\
\hline 70 & Chauffeurs & 96,0 & 0,7 & 1,6 \\
\hline 71 & Schippers en conducteurs & 96,2 & 0,7 & 1,3 \\
\hline 72 & $\begin{array}{l}\text { Vliegers, scheepskapiteins en } \\
\text { leidinggevenden transport }\end{array}$ & 96,9 & 0,4 & 0,8 \\
\hline 73 & Stewards & 94,3 & 1,9 & 1,9 \\
\hline 74 & $\begin{array}{l}\text { Verpleeghulpen en leerling- } \\
\text { verpleegkundigen }\end{array}$ & 93,7 & 1,1 & 1,4 \\
\hline 75 & Verplegenden en doktersassistenten & 96,6 & 0,3 & 0,4 \\
\hline 76 & Therapeuten en verpleegkundigen & 97,8 & 0,1 & 0,5 \\
\hline 77 & Artsen & 98,6 & 0,3 & 0,5 \\
\hline 78 & $\begin{array}{l}\text { Apothekersassistenten en medisch } \\
\text { laboranten }\end{array}$ & 97,6 & 0,4 & 0,6 \\
\hline 79 & Medisch analisten & 97,7 & 0,2 & 1,1 \\
\hline 80 & Apothekers & 97,6 & 0,3 & 0,5 \\
\hline 81 & Afdelingshoofden zorginstelling & 93,9 & 0,7 & 1,4 \\
\hline 82 & Kantoorhulpen, inpakkers en colporteurs & 82,7 & 2,6 & 8,6 \\
\hline 83 & $\begin{array}{l}\text { Ondersteunende administratieve } \\
\text { hulpkrachten }\end{array}$ & 85,2 & 1,8 & 7,2 \\
\hline 84 & Bedrijfshoofden & 95,7 & 0,4 & 1,2 \\
\hline 85 & Economen & 94,2 & 0,6 & 1,6 \\
\hline 86 & Productieplanners & 95,2 & 0,6 & 0,9 \\
\hline 87 & Organisatie-adviseurs & 93,7 & 0,8 & 1,1 \\
\hline 88 & Organisatiedeskundigen & 95,2 & 0,6 & 0,9 \\
\hline 89 & $\begin{array}{l}\text { Receptionisten en administratieve } \\
\text { employés }\end{array}$ & 92,5 & 1,1 & 2,7 \\
\hline 90 & Boekhouders en secretaresses & 95,4 & 0,7 & 1,3 \\
\hline
\end{tabular}




\begin{tabular}{|c|c|c|c|c|}
\hline 91 & Assistent accountants & 96,6 & $\overline{0,6}$ & 0,7 \\
\hline 92 & Accountants & 96,9 & 0,2 & 0,6 \\
\hline 93 & Verzekeringsagenten & 94,9 & 0,8 & 1,4 \\
\hline 94 & Commercieel employés & 95,5 & 0,8 & 1,1 \\
\hline 95 & Commercieel medewerkers & 96,6 & 0,5 & 0,7 \\
\hline 96 & Technisch-commercieel employés & 95,8 & 0,5 & 0,8 \\
\hline 97 & Technisch-bedrijfskundig medewerkers & 94,0 & 0,7 & 1,1 \\
\hline 98 & Juridisch en fiscaal medewerkers & 97,8 & 0,1 & 0,9 \\
\hline 99 & Juridisch, bestuurlijk medewerkers & 95,0 & 0,4 & 1,4 \\
\hline 100 & Juristen & 97,2 & 0,3 & 0,9 \\
\hline 101 & Administratieve transportemployés & 95,5 & 0,8 & 1,0 \\
\hline 102 & Leidinggevenden & 96,5 & 0,3 & 0,8 \\
\hline 103 & Managers & 95,9 & 0,4 & 1,2 \\
\hline 104 & Medisch secretaresses & 93,9 & 1,5 & 1,5 \\
\hline 105 & Programmeurs & 95,1 & 0,8 & 1,2 \\
\hline 106 & Systeemanalisten & 96,8 & 0,6 & 0,5 \\
\hline 107 & Informatici & 95,0 & 0,6 & 0,3 \\
\hline 108 & Technisch systeemanalisten & 95,8 & 0,3 & 1,4 \\
\hline 109 & $\begin{array}{l}\text { Activiteitenbegeleiders en medewerkers } \\
\text { arbeidsbemiddeling }\end{array}$ & 95,4 & 0,4 & 1,1 \\
\hline 110 & $\begin{array}{l}\text { Medewerkers sociaal-cultureel werk en } \\
\text { personeel en arbeid }\end{array}$ & 95,5 & 0,6 & 0,9 \\
\hline 111 & $\begin{array}{l}\text { Hoofden sociaal-cultureel werk en } \\
\text { personeel en arbeid }\end{array}$ & 95,8 & 0,2 & 1,7 \\
\hline 112 & Sociaal-wetenschappelijk medewerkers & 95,9 & 0,1 & 1,3 \\
\hline 113 & Sociaal-wetenschappelijk onderzoekers & 96,6 & 0,1 & 0,8 \\
\hline 114 & Vakkenvullers & 78,0 & 1,3 & 14,1 \\
\hline 115 & Interieurverzorgers & 84,3 & 1,7 & 8,8 \\
\hline 116 & Verkopers & 90,8 & 1,1 & 4,0 \\
\hline 117 & Winkeliers & 96,8 & 0,5 & 0,9 \\
\hline 118 & Hulpkrachten horeca en verzorging & 83,5 & 1,9 & 8,3 \\
\hline 119 & Ziekenverzorgenden & 94,5 & 0,5 & 0,7 \\
\hline 120 & Verzorgend personeel & 94,8 & 0,8 & 1,5 \\
\hline 121 & Café- en snackbarhouders & 95,6 & 0,6 & 1,7 \\
\hline 122 & Bedrijfshoofden horeca & 95,5 & 0,7 & 1,3 \\
\hline 124 & $\begin{array}{l}\text { Aspirant politieagenten, soldaten en } \\
\text { beveiligingshulpkrachte }\end{array}$ & 94,6 & 1,1 & 1,2 \\
\hline
\end{tabular}




\begin{tabular}{r|l|c|c|c}
\hline \hline 125 & $\begin{array}{l}\text { Politieagenten, onderofficieren en } \\
\text { beveiligingsemployés }\end{array}$ & 97,2 & 0,0 & 0,7 \\
126 & Politie-inspecteurs en officieren & 96,0 & 0,1 & 1,7 \\
& Brandweerlieden & 96,1 & 0,7 & 0,7 \\
& Werkloosheid & 50,5 & 22,6 \\
& Non-participatie & 92,2 & 3,0 & \\
\hline \hline
\end{tabular}

Tabel B4.3 Beroepenmobiliteit naar richting (zelfde beroep, werkloosheid en non-participatie), vrouwen (ongewogen)

\begin{tabular}{|c|c|c|c|c|}
\hline Beroep & & $\begin{array}{c}\text { Werkzaam } \\
\text { in zelfde } \\
\text { beroep }\end{array}$ & $\begin{array}{c}\text { Mobiliteit } \\
\text { richting } \\
\text { werkloosheid }\end{array}$ & $\begin{array}{c}\text { Mobiliteit } \\
\text { richting non- } \\
\text { participatie }\end{array}$ \\
\hline 1 & Leraar basisonderwijs & 97,5 & 0,3 & 1,4 \\
\hline 2 & $\begin{array}{l}\text { Docenten exacte, medische en } \\
\text { verzorgende vakken ( } 2 \mathrm{e} \text { graads) }\end{array}$ & 95,6 & 0,6 & 1,9 \\
\hline 3 & $\begin{array}{l}\text { Docenten exacte, medische en } \\
\text { verzorgende vakken (1e graads) }\end{array}$ & 95,8 & 0,7 & 1,5 \\
\hline 4 & $\begin{array}{l}\text { Docenten landbouw en techniek ( } 2 \mathrm{e} \\
\text { graads) }\end{array}$ & 95,2 & 0,0 & 3,1 \\
\hline 5 & $\begin{array}{l}\text { Docenten landbouw en techniek ( } 1 \mathrm{e} \\
\text { graads) }\end{array}$ & 93,8 & 0,0 & 4,9 \\
\hline 6 & $\begin{array}{l}\text { Docenten economisch-administratieve } \\
\text { vakken ( } 2 \text { e graads) }\end{array}$ & 94,7 & 0,8 & 2,8 \\
\hline 7 & $\begin{array}{l}\text { Docenten economisch-administratieve } \\
\text { vakken (1e graads) }\end{array}$ & 95,3 & 0,0 & 1,4 \\
\hline 8 & Docenten talen en expressie & 95,1 & 0,5 & 2,7 \\
\hline 9 & Docenten letteren (1e graads) & 95,8 & 0,2 & 2,4 \\
\hline 10 & Docenten sociale vakken (2e graads) & 93,6 & 0,2 & 3,4 \\
\hline 11 & Docenten sociale vakken (1e graads) & 93,3 & 0,6 & 1,7 \\
\hline 12 & Docenten 2e graads zonder specialisatie & 95,9 & 0,4 & 2,8 \\
\hline 13 & Docent 1e graads zonder specialisatie & 96,6 & 0,0 & 0,9 \\
\hline 14 & Onderwijskundig medewerkers & 92,5 & 0,6 & 2,4 \\
\hline 15 & Onderwijskundigen en pedagogen & 95,8 & 0,6 & 1,3 \\
\hline 16 & Rij-instructeurs & 96,8 & 0,6 & 1,9 \\
\hline 17 & Zweminstructeurs & 95,4 & 1,1 & 2,3 \\
\hline 18 & Sportinstructeurs & 88,3 & 1,6 & 7,6 \\
\hline 19 & Tolken, vertalers en schrijvers & 93,8 & 0,7 & 3,3 \\
\hline 20 & Bibliotheekassistenten & 94,6 & 0,8 & 2,4 \\
\hline 21 & Bibliothecarissen & 98,5 & 0,0 & 0,5 \\
\hline
\end{tabular}




\begin{tabular}{|c|c|c|c|c|}
\hline 22 & Grafisch ontwerpers & 93,7 & 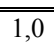 & 2,9 \\
\hline 23 & Kunstenaars & 93,5 & 0,9 & 3,0 \\
\hline 24 & Geestelijk verzorgers & 91,7 & 8,3 & 0,0 \\
\hline 25 & Geestelijken & 99,1 & 0,0 & 0,0 \\
\hline 26 & Journalisten & 94,7 & 0,6 & 2,0 \\
\hline 27 & Taalkundigen & 93,4 & 1,0 & 2,0 \\
\hline 28 & Agrarische hulparbeiders & 81,0 & 3,4 & 13,2 \\
\hline 29 & Agrarische arbeiders & 87,6 & 1,8 & 7,3 \\
\hline 30 & Agrarische vakkrachten & 94,6 & 1,1 & 1,7 \\
\hline 31 & $\begin{array}{l}\text { Milieuhygiënisten en agrarisch } \\
\text { vertegenwoordigers }\end{array}$ & 94,9 & 0,3 & 2,0 \\
\hline 32 & Landbouwkundigen & 95,5 & 1,5 & 0,7 \\
\hline 33 & Landbouwmachinebestuurders en vissers & 91,7 & 4,2 & 4,2 \\
\hline 34 & Agrarische bedrijfshoofden & 96,5 & 0,0 & 2,3 \\
\hline 35 & Productiemedewerkers & 90,2 & 1,6 & 4,1 \\
\hline 36 & Laboratorium-assistenten & 99,5 & 0,0 & 0,5 \\
\hline 37 & Laboranten & 96,7 & 0,3 & 1,5 \\
\hline 38 & Technisch analisten & 95,7 & 1,4 & 0,6 \\
\hline 39 & Natuurwetenschappers & 94,6 & 0,9 & 0,3 \\
\hline 40 & Conciërges & 94,6 & 0,5 & 2,6 \\
\hline 41 & Hoofden technische dienst & 97,3 & 0,0 & 0,7 \\
\hline 42 & Werktuigbouwkundigen & 93,2 & 0,0 & 2,7 \\
\hline 43 & Bouwvakkers & 92,6 & 1,4 & 3,2 \\
\hline 44 & Aannemers en installateurs & 94,2 & 0,4 & 2,2 \\
\hline 45 & $\begin{array}{l}\text { Architecten en bouwkundig } \\
\text { projectleiders }\end{array}$ & 94,8 & 0,2 & 2,3 \\
\hline 46 & Weg- en waterbouwkundigen & 94,4 & 1,9 & 1,2 \\
\hline 47 & Weg- en waterbouwkundige arbeiders & 85,7 & 0,0 & 0,0 \\
\hline 48 & Weg- en waterbouwkundige vakkrachten & 98,8 & 0,0 & 0,0 \\
\hline 49 & $\begin{array}{l}\text { Weg- en waterbouwkundig ontwerpers } \\
\text { en projectleiders }\end{array}$ & 95,7 & 0,9 & 0,0 \\
\hline 50 & Metaalarbeiders & 91,8 & 1,8 & 3,6 \\
\hline 51 & Bankwerkers en lassers & 91,7 & 1,5 & 3,7 \\
\hline
\end{tabular}




\begin{tabular}{|c|c|c|c|c|}
\hline 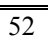 & Bedrijfshoofden metaalbewerking & 90,2 & $\overline{0,0}$ & $\overline{3,3}$ \\
\hline 53 & Assembleurs & 90,5 & 3,6 & 3,6 \\
\hline 54 & Monteurs & 94,5 & 1,3 & 1,0 \\
\hline 55 & $\begin{array}{l}\text { Werktuigbouwkundig ontwerpers en } \\
\text { hoofden technische dienst }\end{array}$ & 92,6 & 2,2 & 0,0 \\
\hline 56 & Elektronicamonteurs & 88,9 & 2,2 & 4,4 \\
\hline 57 & $\begin{array}{l}\text { Monteurs en controleurs } \\
\text { elektrotechnische producten }\end{array}$ & 84,8 & 4,0 & 6,4 \\
\hline 58 & Elektromonteurs & 96,7 & 1,4 & 0,0 \\
\hline 59 & $\begin{array}{l}\text { Elektrotechnisch ontwerpers en } \\
\text { bedrijfshoofden }\end{array}$ & 100,0 & 0,0 & 0,0 \\
\hline 60 & Elektrotechnici & 96,4 & 3,6 & 0,0 \\
\hline 61 & Grafisch productiepersoneel & 95,5 & 0,9 & 1,7 \\
\hline 62 & Grafische vakkrachten & 94,3 & 0,9 & 1,6 \\
\hline 63 & Mechanisch operators & 91,7 & 2,8 & 2,9 \\
\hline 65 & Procestechnologen & 94,9 & 0,0 & 0,6 \\
\hline 66 & Materiaalkundigen & 93,8 & 3,1 & 0,6 \\
\hline 67 & Confectie-arbeiders & 94,4 & 1,2 & 2,9 \\
\hline 68 & Schoen- en kleermakers & 96,5 & 0,0 & 2,0 \\
\hline 69 & Laders en lossers & 89,7 & 2,4 & 4,4 \\
\hline 70 & Chauffeurs & 91,9 & 1,2 & 4,0 \\
\hline 71 & Schippers en conducteurs & 94,1 & 0,5 & 3,0 \\
\hline 72 & $\begin{array}{l}\text { Vliegers, scheepskapiteins en } \\
\text { leidinggevenden transport }\end{array}$ & 94,9 & 0,0 & 1,0 \\
\hline 73 & Stewards & 94,5 & 0,6 & 2,6 \\
\hline 74 & $\begin{array}{l}\text { Verpleeghulpen en leerling- } \\
\text { verpleegkundigen }\end{array}$ & 91,4 & 0,8 & 3,0 \\
\hline 75 & Verplegenden en doktersassistenten & 96,7 & 0,3 & 1,4 \\
\hline 76 & Therapeuten en verpleegkundigen & 96,8 & 0,3 & 1,3 \\
\hline 77 & Artsen & 96,9 & 0,5 & 1,0 \\
\hline 78 & $\begin{array}{l}\text { Apothekersassistenten en medisch } \\
\text { laboranten }\end{array}$ & 97,5 & 0,4 & 1,1 \\
\hline 79 & Medisch analisten & 98,2 & 0,2 & 0,7 \\
\hline 80 & Apothekers & 98,0 & 0,3 & 0,3 \\
\hline 81 & Afdelingshoofden zorginstelling & 94,7 & 0,2 & 0,7 \\
\hline 82 & Kantoorhulpen, inpakkers en colporteurs & 85,1 & 3,2 & 7,3 \\
\hline 83 & $\begin{array}{l}\text { Ondersteunende administratieve } \\
\text { hulpkrachten }\end{array}$ & 83,3 & 3,9 & 6,1 \\
\hline 84 & Bedrijfshoofden & 92,4 & 0,4 & 2,3 \\
\hline
\end{tabular}




\begin{tabular}{|c|c|c|c|c|}
\hline$\overline{85}$ & Economen & 94,9 & 0,5 & 0,9 \\
\hline 86 & Productieplanners & 94,3 & 1,0 & 1,5 \\
\hline 87 & Organisatie-adviseurs & 93,0 & 1,1 & 0,6 \\
\hline 88 & Organisatiedeskundigen & 95,4 & 0,5 & 1,0 \\
\hline 89 & $\begin{array}{l}\text { Receptionisten en administratieve } \\
\text { employés }\end{array}$ & 93,6 & 1,3 & 2,4 \\
\hline 90 & Boekhouders en secretaresses & 96,0 & 0,8 & 1,4 \\
\hline 91 & Assistent accountants & 95,4 & 0,6 & 0,9 \\
\hline 92 & Accountants & 96,5 & 0,3 & 0,3 \\
\hline 93 & Verzekeringsagenten & 93,7 & 0,6 & 2,4 \\
\hline 94 & Commercieel employés & 93,6 & 1,3 & 1,7 \\
\hline 95 & Commercieel medewerkers & 94,5 & 0,8 & 1,1 \\
\hline 96 & Technisch-commercieel employés & 96,4 & 0,4 & 1,4 \\
\hline 97 & Technisch-bedrijfskundig medewerkers & 92,6 & 2,5 & 1,5 \\
\hline 98 & Juridisch en fiscaal medewerkers & 96,3 & 0,7 & 0,6 \\
\hline 99 & Juridisch, bestuurlijk medewerkers & 94,3 & 0,4 & 0,7 \\
\hline 100 & Juristen & 96,8 & 0,6 & 1,0 \\
\hline 101 & Administratieve transportemployés & 95,3 & 0,6 & 1,4 \\
\hline 102 & Leidinggevenden & 96,2 & 0,1 & 0,6 \\
\hline 103 & Managers & 95,1 & 0,4 & 0,6 \\
\hline 104 & Medisch secretaresses & 97,0 & 0,6 & 1,0 \\
\hline 105 & Programmeurs & 93,9 & 1,9 & 0,9 \\
\hline 106 & Systeemanalisten & 94,7 & 0,7 & 1,0 \\
\hline 107 & Informatici & 94,0 & 1,5 & 0,9 \\
\hline 108 & Technisch systeemanalisten & 86,7 & 0,0 & 6,7 \\
\hline 109 & $\begin{array}{l}\text { Activiteitenbegeleiders en medewerkers } \\
\text { arbeidsbemiddeling }\end{array}$ & 93,5 & 0,8 & 1,9 \\
\hline 110 & $\begin{array}{l}\text { Medewerkers sociaal-cultureel werk en } \\
\text { personeel en arbeid }\end{array}$ & 95,2 & 0,8 & 1,0 \\
\hline 111 & $\begin{array}{l}\text { Hoofden sociaal-cultureel werk en } \\
\text { personeel en arbeid }\end{array}$ & 95,9 & 0,5 & 0,7 \\
\hline 112 & Sociaal-wetenschappelijk medewerkers & 97,3 & 0,0 & 0,7 \\
\hline 113 & Sociaal-wetenschappelijk onderzoekers & 96,5 & 0,6 & 0,7 \\
\hline 114 & Vakkenvullers & 84,3 & 1,2 & 9,9 \\
\hline 115 & Interieurverzorgers & 89,7 & 1,3 & 6,0 \\
\hline
\end{tabular}




\begin{tabular}{|c|c|c|c|c|}
\hline 116 & Verkopers & 91,3 & 1,3 & 4,7 \\
\hline 117 & Winkeliers & 95,6 & 0,7 & 1,5 \\
\hline 118 & Hulpkrachten horeca en verzorging & 89,4 & 0,9 & 6,4 \\
\hline 119 & Ziekenverzorgenden & 96,2 & 0,2 & 1,6 \\
\hline 120 & Verzorgend personeel & 95,0 & 0,6 & 2,2 \\
\hline 121 & Café- en snackbarhouders & 96,3 & 0,0 & 2,0 \\
\hline 122 & Bedrijfshoofden horeca & 95,5 & 0,6 & 1,7 \\
\hline 124 & $\begin{array}{l}\text { Aspirant politieagenten, soldaten en } \\
\text { beveiligingshulpkrachte }\end{array}$ & 92,6 & 1,5 & 2,5 \\
\hline 125 & $\begin{array}{l}\text { Politieagenten, onderofficieren en } \\
\text { beveiligingsemployés }\end{array}$ & 97,4 & 0,1 & 0,1 \\
\hline 126 & Politie-inspecteurs en officieren & 96,0 & 0,0 & 1,3 \\
\hline \multirow[t]{3}{*}{127} & Brandweerlieden & 93,3 & 2,2 & 0,0 \\
\hline & Werkloosheid & 43,9 & & 33,8 \\
\hline & Non-participatie & 93,7 & 3,1 & \\
\hline
\end{tabular}


Bijlage 5: Beroepenmobiliteit (1 digit)

Tabel B5.1: Mobiliteit tussen beroepen (1 digit) tussen eerste meting en tweede meting, 2002 en 2005 (ongewogen)

\begin{tabular}{|c|c|c|c|c|c|c|c|c|c|c|c|c|}
\hline$n^{t+1}$ & $\begin{array}{l}\text { Elementaire } \\
\text { beroepen }\end{array}$ & $\begin{array}{c}\text { Lagere } \\
\text { Beroepen } \\
\text { (techniek } \\
\text { etc) }\end{array}$ & $\begin{array}{l}\text { Lagere adm., } \\
\text { commerciële } \\
\text { beroepen } \\
\text { e.d. }\end{array}$ & $\begin{array}{l}\text { Middelbare } \\
\text { beroepen } \\
\text { (techniek } \\
\text { etc) }\end{array}$ & $\begin{array}{l}\text { Middelbare } \\
\text { adm., } \\
\text { commerciële } \\
\text { beroepen } \\
\text { e.d. }\end{array}$ & $\begin{array}{c}\text { Hogere } \\
\text { beroepen } \\
\text { (techniek } \\
\text { etc) }\end{array}$ & $\begin{array}{c}\text { Hogere } \\
\text { adm., } \\
\text { commerciële } \\
\text { beroepen } \\
\text { e.d. }\end{array}$ & $\begin{array}{l}\text { Wetenschap- } \\
\text { pelijke } \\
\text { beroepen } \\
\text { (techniek } \\
\text { etc) }\end{array}$ & $\begin{array}{l}\text { Wetenschap- } \\
\text { pelijke } \\
\text { economische } \\
\text { adm. } \\
\text { beroepen } \\
\text { e.d. }\end{array}$ & $\begin{array}{l}\text { Werkloos- } \\
\text { heid }\end{array}$ & $\begin{array}{c}\text { Non- } \\
\text { participatie }\end{array}$ & $\begin{array}{c}\mathrm{N} \\
(\mathrm{x} \quad 1000)\end{array}$ \\
\hline Elementaire beroepen & 90,0 & 0,9 & 1,0 & 0,5 & 0,4 & 0,1 & 0,1 & 0,0 & 0,0 & 2,0 & 5,0 & 11,3 \\
\hline $\begin{array}{l}\text { Lagere Beroepen (techniek } \\
\text { etc) }\end{array}$ & 0,4 & 95,2 & 0,2 & 0,6 & 0,3 & 0,1 & 0,1 & 0,0 & 0,0 & 1,0 & 2,2 & 21,3 \\
\hline $\begin{array}{l}\text { Lagere adm., commerciele } \\
\text { beroepen e.d. }\end{array}$ & 0,3 & 0,2 & 93,1 & 0,2 & 1,1 & 0,1 & 0,2 & 0,0 & 0,0 & 1,3 & 3,5 & 20,0 \\
\hline $\begin{array}{l}\text { Middelbare beroepen } \\
\text { (techniek etc) }\end{array}$ & 0,1 & 0,2 & 0,1 & 97,3 & 0,3 & 0,2 & 0,2 & 0,0 & 0,1 & 0,5 & 1,1 & 32,5 \\
\hline $\begin{array}{l}\text { Middelbare adm, } \\
\text { commerciele beroepen e.d. }\end{array}$ & 0,1 & 0,1 & 0,4 & 0,2 & 96,2 & 0,1 & 0,5 & 0,0 & 0,1 & 0,8 & 1,4 & 40,5 \\
\hline $\begin{array}{l}\text { Hogere beroepen (techniek } \\
\text { etc) }\end{array}$ & 0,0 & 0,0 & 0,1 & 0,2 & 0,2 & 97,2 & 0,4 & 0,2 & 0,2 & 0,4 & 1,2 & 17,8 \\
\hline $\begin{array}{l}\text { Hogere adm, commerciele } \\
\text { beroepen e.d. }\end{array}$ & 0,0 & 0,0 & 0,1 & 0,2 & 0,8 & 0,3 & 96,4 & 0,1 & 0,4 & 0,7 & 0,9 & 23,7 \\
\hline $\begin{array}{l}\text { Wetenschappelijke } \\
\text { beroepen (techniek etc) }\end{array}$ & 0,0 & 0,0 & 0,0 & 0,1 & 0,1 & 0,4 & 0,5 & 97,0 & 0,3 & 0,6 & 0,9 & 6,7 \\
\hline $\begin{array}{l}\text { Wetenschappelijke } \\
\text { economische adm. } \\
\text { beroepen e.d. }\end{array}$ & 0,0 & 0,0 & 0,1 & 0,0 & 0,3 & 0,2 & 0,9 & 0,3 & 96,8 & 0,4 & 1,0 & 9,1 \\
\hline Werkloosheid & 3,5 & 3,7 & 5,1 & 2,7 & 5,2 & 1,4 & 2,0 & 0,7 & 0,7 & 43,9 & 31,2 & 9,1 \\
\hline Non-participatie & 0,7 & 0,5 & 0,9 & 0,3 & 0,6 & 0,2 & 0,2 & 0,1 & 0,1 & 3,0 & 93,4 & 88,4 \\
\hline
\end{tabular}


Tabel B5.2: Mobiliteit tussen beroepen (1 digit) tussen tweede meting en derde meting, 2002 en 2005 (ongewogen)

\begin{tabular}{|c|c|c|c|c|c|c|c|c|c|c|c|c|}
\hline$n^{t+1}$ & $\begin{array}{c}\text { Elementaire } \\
\text { beroepen }\end{array}$ & $\begin{array}{c}\text { Lagere } \\
\text { Beroepen } \\
\text { (techniek } \\
\text { etc) }\end{array}$ & $\begin{array}{l}\text { Lagere adm., } \\
\text { commerciële } \\
\text { beroepen } \\
\text { e.d. }\end{array}$ & $\begin{array}{l}\text { Middelbare } \\
\text { beroepen } \\
\text { (techniek } \\
\text { etc) }\end{array}$ & $\begin{array}{l}\text { Middelbare } \\
\text { adm., } \\
\text { commerciële } \\
\text { beroepen } \\
\text { e.d. }\end{array}$ & $\begin{array}{c}\text { Hogere } \\
\text { beroepen } \\
\text { (techniek } \\
\text { etc) }\end{array}$ & $\begin{array}{l}\text { Hogere } \\
\text { adm., } \\
\text { commerciële } \\
\text { beroepen } \\
\text { e.d. }\end{array}$ & $\begin{array}{l}\text { Wetenschap- } \\
\text { pelijke } \\
\text { beroepen } \\
\text { (techniek } \\
\text { etc) }\end{array}$ & $\begin{array}{l}\text { Wetenschap- } \\
\text { pelijke } \\
\text { economische } \\
\text { adm. } \\
\text { beroepen } \\
\text { e.d. }\end{array}$ & $\begin{array}{l}\text { Werkloos- } \\
\text { heid }\end{array}$ & $\begin{array}{c}\text { Non- } \\
\text { participatie }\end{array}$ & $\begin{array}{c}\mathrm{N} \\
(\mathrm{x} 1000)\end{array}$ \\
\hline Elementaire beroepen & 89,1 & 1,0 & 0,8 & 0,4 & 0,6 & 0,1 & 0,1 & 0,0 & 0,0 & 1,8 & 6,0 & 11,0 \\
\hline $\begin{array}{l}\text { Lagere Beroepen (techniek } \\
\text { etc) }\end{array}$ & 0,4 & 95,2 & 0,2 & 0,6 & 0,2 & 0,1 & 0,0 & 0,0 & 0,0 & 1,0 & 2,2 & 20,9 \\
\hline $\begin{array}{l}\text { Lagere adm., commerciele } \\
\text { beroepen e.d. }\end{array}$ & 0,4 & 0,2 & 91,8 & 0,3 & 1,3 & 0,1 & 0,1 & 0,0 & 0,1 & 1,3 & 4,5 & 19,9 \\
\hline $\begin{array}{l}\text { Middelbare beroepen } \\
\text { (techniek etc) }\end{array}$ & 0,1 & 0,3 & 0,1 & 97,1 & 0,4 & 0,2 & 0,2 & 0,0 & 0,1 & 0,5 & 1,1 & 32,1 \\
\hline $\begin{array}{l}\text { Middelbare adm, } \\
\text { commerciele beroepen e.d. }\end{array}$ & 0,1 & 0,1 & 0,4 & 0,3 & 96,0 & 0,1 & 0,6 & 0,0 & 0,1 & 0,7 & 1,4 & 39,8 \\
\hline $\begin{array}{l}\text { Hogere beroepen (techniek } \\
\text { etc) }\end{array}$ & 0,0 & 0,0 & 0,1 & 0,3 & 0,2 & 97,1 & 0,4 & 0,2 & 0,1 & 0,3 & 1,3 & 17,8 \\
\hline $\begin{array}{l}\text { Hogere adm, commerciele } \\
\text { beroepen e.d. }\end{array}$ & 0,0 & 0,0 & 0,1 & 0,1 & 0,7 & 0,3 & 96,7 & 0,1 & 0,4 & 0,6 & 0,9 & 23,4 \\
\hline $\begin{array}{l}\text { Wetenschappelijke } \\
\text { beroepen (techniek etc) }\end{array}$ & 0,0 & 0,0 & 0,0 & 0,2 & 0,1 & 0,3 & 0,4 & 97,0 & 0,5 & 0,5 & 1,0 & 6,6 \\
\hline $\begin{array}{l}\text { Wetenschappelijke } \\
\text { economische adm. } \\
\text { beroepen e.d. }\end{array}$ & 0,0 & 0,1 & 0,1 & 0,1 & 0,4 & 0,2 & 1,0 & 0,2 & 96,9 & 0,4 & 0,7 & 9,0 \\
\hline Werkloosheid & 3,3 & 3,8 & 4,8 & 2,5 & 4,9 & 1,4 & 2,2 & 0,7 & 0,7 & 46,9 & 28,9 & 7,4 \\
\hline Non-participatie & 0,8 & 0,5 & 0,9 & 0,4 & 0,6 & 0,2 & 0,2 & 0,1 & 0,1 & 3,3 & 93,0 & 84,0 \\
\hline
\end{tabular}


Tabel B5.3: Mobiliteit tussen beroepen (1 digit) tussen derde meting en vierde meting, 2002 en 2005 (ongewogen)

\begin{tabular}{|c|c|c|c|c|c|c|c|c|c|c|c|c|}
\hline$n^{t+1}$ & $\begin{array}{c}\text { Elementaire } \\
\text { beroepen }\end{array}$ & $\begin{array}{c}\text { Lagere } \\
\text { Beroepen } \\
\text { (techniek } \\
\text { etc) }\end{array}$ & $\begin{array}{l}\text { Lagere adm., } \\
\text { commerciële } \\
\text { beroepen } \\
\text { e.d. }\end{array}$ & $\begin{array}{l}\text { Middelbare } \\
\text { beroepen } \\
\text { (techniek } \\
\text { etc) }\end{array}$ & $\begin{array}{l}\text { Middelbare } \\
\text { adm., } \\
\text { commerciële } \\
\text { beroepen } \\
\text { e.d. }\end{array}$ & $\begin{array}{c}\text { Hogere } \\
\text { beroepen } \\
\text { (techniek } \\
\text { etc) }\end{array}$ & $\begin{array}{l}\text { Hogere } \\
\text { adm., } \\
\text { commerciële } \\
\text { beroepen } \\
\text { e.d. }\end{array}$ & $\begin{array}{l}\text { Wetenschap- } \\
\text { pelijke } \\
\text { beroepen } \\
\text { (techniek } \\
\text { etc) }\end{array}$ & $\begin{array}{l}\text { Wetenschap- } \\
\text { pelijke } \\
\text { economische } \\
\text { adm. } \\
\text { beroepen } \\
\text { e.d. }\end{array}$ & $\begin{array}{l}\text { Werkloos- } \\
\text { heid }\end{array}$ & $\begin{array}{c}\text { Non- } \\
\text { participatie }\end{array}$ & $\begin{array}{c}\mathrm{N} \\
(\mathrm{x} 1000)\end{array}$ \\
\hline Elementaire beroepen & 88,7 & 0,8 & 0,8 & 0,4 & 0,6 & 0,1 & 0,1 & 0,0 & 0,0 & 1,7 & 6,6 & 10,9 \\
\hline $\begin{array}{l}\text { Lagere Beroepen (techniek } \\
\text { etc) }\end{array}$ & 0,3 & 95,5 & 0,2 & 0,7 & 0,2 & 0,0 & 0,1 & 0,0 & 0,0 & 1,0 & 1,9 & 20,7 \\
\hline $\begin{array}{l}\text { Lagere adm., commerciele } \\
\text { beroepen e.d. }\end{array}$ & 0,4 & 0,2 & 92,5 & 0,3 & 1,1 & 0,1 & 0,2 & 0,0 & 0,0 & 1,2 & 4,0 & 19,4 \\
\hline $\begin{array}{l}\text { Middelbare beroepen } \\
\text { (techniek etc) }\end{array}$ & 0,1 & 0,3 & 0,1 & 97,2 & 0,3 & 0,2 & 0,1 & 0,0 & 0,1 & 0,5 & 1,1 & 32,0 \\
\hline $\begin{array}{l}\text { Middelbare adm, } \\
\text { commerciele beroepen e.d. }\end{array}$ & 0,1 & 0,1 & 0,4 & 0,2 & 96,2 & 0,1 & 0,6 & 0,0 & 0,1 & 0,7 & 1,5 & 39,3 \\
\hline $\begin{array}{l}\text { Hogere beroepen (techniek } \\
\text { etc) }\end{array}$ & 0,0 & 0,0 & 0,1 & 0,2 & 0,3 & 97,0 & 0,4 & 0,2 & 0,2 & 0,3 & 1,3 & 17,7 \\
\hline $\begin{array}{l}\text { Hogere adm, commerciele } \\
\text { beroepen e.d. }\end{array}$ & 0,0 & 0,1 & 0,1 & 0,2 & 0,8 & 0,3 & 96,4 & 0,1 & 0,5 & 0,5 & 0,9 & 23,1 \\
\hline $\begin{array}{l}\text { Wetenschappelijke } \\
\text { beroepen (techniek etc) }\end{array}$ & 0,0 & 0,0 & 0,0 & 0,2 & 0,1 & 0,3 & 0,4 & 96,7 & 0,4 & 0,6 & 1,2 & 6,6 \\
\hline $\begin{array}{l}\text { Wetenschappelijke } \\
\text { economische adm. } \\
\text { beroepen e.d. }\end{array}$ & 0,0 & 0,0 & 0,1 & 0,1 & 0,3 & 0,2 & 1,0 & 0,4 & 96,6 & 0,5 & 0,9 & 8,9 \\
\hline Werkloosheid & 3,0 & 3,4 & 4,4 & 2,1 & 4,8 & 1,4 & 1,8 & 0,5 & 0,7 & 49,9 & 27,8 & 7,2 \\
\hline Non-participatie & 0,8 & 0,5 & 0,9 & 0,3 & 0,6 & 0,2 & 0,2 & 0,1 & 0,0 & 3,0 & 93,4 & 81,5 \\
\hline
\end{tabular}


Tabel B5.4: Mobiliteit tussen beroepen (1 digit) tussen vierde meting en vijfde meting, 2002 en 2005 (ongewogen)

\begin{tabular}{|c|c|c|c|c|c|c|c|c|c|c|c|c|}
\hline$n^{t+1}$ & $\begin{array}{c}\text { Elementaire } \\
\text { beroepen }\end{array}$ & $\begin{array}{c}\text { Lagere } \\
\text { Beroepen } \\
\text { (techniek } \\
\text { etc) }\end{array}$ & $\begin{array}{l}\text { Lagere adm., } \\
\text { commerciële } \\
\text { beroepen } \\
\text { e.d. }\end{array}$ & $\begin{array}{l}\text { Middelbare } \\
\text { beroepen } \\
\text { (techniek } \\
\text { etc) }\end{array}$ & $\begin{array}{l}\text { Middelbare } \\
\text { adm., } \\
\text { commerciële } \\
\text { beroepen } \\
\text { e.d. }\end{array}$ & $\begin{array}{c}\text { Hogere } \\
\text { beroepen } \\
\text { (techniek } \\
\text { etc) }\end{array}$ & $\begin{array}{l}\text { Hogere } \\
\text { adm., } \\
\text { commerciële } \\
\text { beroepen } \\
\text { e.d. }\end{array}$ & $\begin{array}{l}\text { Wetenschap- } \\
\text { pelijke } \\
\text { beroepen } \\
\text { (techniek } \\
\text { etc) }\end{array}$ & $\begin{array}{l}\text { Wetenschap- } \\
\text { pelijke } \\
\text { economische } \\
\text { adm. } \\
\text { beroepen } \\
\text { e.d. }\end{array}$ & $\begin{array}{l}\text { Werkloos- } \\
\text { heid }\end{array}$ & $\begin{array}{c}\text { Non- } \\
\text { participatie }\end{array}$ & $\begin{array}{c}\mathrm{N} \\
(\mathrm{x} 1000)\end{array}$ \\
\hline Elementaire beroepen & 88,8 & 0,8 & 0,9 & 0,4 & 0,6 & 0,1 & 0,1 & 0,0 & 0,0 & 1,6 & 6,6 & 10,7 \\
\hline $\begin{array}{l}\text { Lagere Beroepen (techniek } \\
\text { etc) }\end{array}$ & 0,3 & 95,4 & 0,3 & 0,6 & 0,2 & 0,1 & 0,1 & 0,0 & 0,0 & 0,9 & 2,1 & 21,0 \\
\hline $\begin{array}{l}\text { Lagere adm., commerciele } \\
\text { beroepen e.d. }\end{array}$ & 0,4 & 0,2 & 92,6 & 0,2 & 1,2 & 0,1 & 0,2 & 0,0 & 0,1 & 1,1 & 4,1 & 19,6 \\
\hline $\begin{array}{l}\text { Middelbare beroepen } \\
\text { (techniek etc) }\end{array}$ & 0,1 & 0,3 & 0,1 & 97,3 & 0,3 & 0,2 & 0,2 & 0,0 & 0,1 & 0,4 & 1,1 & 32,4 \\
\hline $\begin{array}{l}\text { Middelbare adm, } \\
\text { commerciele beroepen e.d. }\end{array}$ & 0,1 & 0,1 & 0,4 & 0,2 & 96,3 & 0,1 & 0,6 & 0,0 & 0,2 & 0,7 & 1,3 & 39,6 \\
\hline $\begin{array}{l}\text { Hogere beroepen (techniek } \\
\text { etc) }\end{array}$ & 0,0 & 0,0 & 0,1 & 0,3 & 0,3 & 97,2 & 0,3 & 0,2 & 0,2 & 0,4 & 1,1 & 17,8 \\
\hline $\begin{array}{l}\text { Hogere adm, commerciele } \\
\text { beroepen e.d. }\end{array}$ & 0,0 & 0,1 & 0,1 & 0,2 & 0,7 & 0,2 & 96,5 & 0,1 & 0,4 & 0,6 & 1,0 & 23,2 \\
\hline $\begin{array}{l}\text { Wetenschappelijke } \\
\text { beroepen (techniek etc) }\end{array}$ & 0,1 & 0,0 & 0,0 & 0,2 & 0,1 & 0,3 & 0,4 & 96,7 & 0,5 & 0,6 & 1,1 & 6,5 \\
\hline $\begin{array}{l}\text { Wetenschappelijke } \\
\text { economische adm. } \\
\text { beroepen e.d. }\end{array}$ & 0,0 & 0,0 & 0,1 & 0,1 & 0,4 & 0,3 & 1,0 & 0,2 & 96,6 & 0,4 & 0,9 & 9,0 \\
\hline Werkloosheid & 3,5 & 3,2 & 4,8 & 2,2 & 4,8 & 1,1 & 1,8 & 0,6 & 0,7 & 49,2 & 28,2 & 7,0 \\
\hline Non-participatie & 0,8 & 0,4 & 0,9 & 0,3 & 0,5 & 0,2 & 0,2 & 0,1 & 0,0 & 2,9 & 93,6 & 81,1 \\
\hline
\end{tabular}


Tabel B5.5: Mobiliteit tussen beroepen tussen kwartalen $t$ en $t+1$ (1 digit) in 2002 (ongewogen)

\begin{tabular}{|c|c|c|c|c|c|c|c|c|c|c|c|c|}
\hline$n^{t+1}$ & $\begin{array}{c}\text { Elementaire } \\
\text { beroepen }\end{array}$ & $\begin{array}{c}\text { Lagere } \\
\text { Beroepen } \\
\text { (techniek } \\
\text { etc) }\end{array}$ & $\begin{array}{l}\text { Lagere adm., } \\
\text { commerciële } \\
\text { beroepen } \\
\text { e.d. }\end{array}$ & $\begin{array}{l}\text { Middelbare } \\
\text { beroepen } \\
\text { (techniek } \\
\text { etc) }\end{array}$ & $\begin{array}{l}\text { Middelbare } \\
\text { adm., } \\
\text { commerciële } \\
\text { beroepen } \\
\text { e.d. }\end{array}$ & $\begin{array}{c}\text { Hogere } \\
\text { beroepen } \\
\text { (techniek } \\
\text { etc) }\end{array}$ & $\begin{array}{l}\text { Hogere } \\
\text { adm., } \\
\text { commerciële } \\
\text { beroepen } \\
\text { e.d. }\end{array}$ & $\begin{array}{l}\text { Wetenschap- } \\
\text { pelijke } \\
\text { beroepen } \\
\text { (techniek } \\
\text { etc) }\end{array}$ & $\begin{array}{l}\text { Wetenschap- } \\
\text { pelijke } \\
\text { economische } \\
\text { adm. } \\
\text { beroepen } \\
\text { e.d. }\end{array}$ & $\begin{array}{l}\text { Werkloos- } \\
\text { heid }\end{array}$ & $\begin{array}{c}\text { Non- } \\
\text { participatie }\end{array}$ & $\begin{array}{c}\mathrm{N} \\
(\mathrm{x} 1000)\end{array}$ \\
\hline Elementaire beroepen & 88,1 & 1,0 & 1,2 & 0,5 & 0,7 & 0,1 & 0,1 & 0,0 & 0,0 & 1,3 & 6,8 & 8,1 \\
\hline $\begin{array}{l}\text { Lagere Beroepen (techniek } \\
\text { etc) }\end{array}$ & 0,4 & 95,2 & 0,3 & 0,6 & 0,3 & 0,1 & 0,1 & 0,0 & 0,0 & 0,8 & 2,2 & 16,7 \\
\hline $\begin{array}{l}\text { Lagere adm., commerciele } \\
\text { beroepen e.d. }\end{array}$ & 0,4 & 0,3 & 91,8 & 0,3 & 1,3 & 0,1 & 0,1 & 0,0 & 0,0 & 1,0 & 4,6 & 14,7 \\
\hline $\begin{array}{l}\text { Middelbare beroepen } \\
\text { (techniek etc) }\end{array}$ & 0,2 & 0,3 & 0,2 & 96,8 & 0,4 & 0,2 & 0,2 & 0,0 & 0,1 & 0,4 & 1,3 & 25,4 \\
\hline $\begin{array}{l}\text { Middelbare adm, } \\
\text { commerciele beroepen e.d. }\end{array}$ & 0,1 & 0,1 & 0,5 & 0,3 & 95,6 & 0,2 & 0,6 & 0,0 & 0,1 & 0,7 & 1,7 & 29,5 \\
\hline $\begin{array}{l}\text { Hogere beroepen (techniek } \\
\text { etc) }\end{array}$ & 0,0 & 0,0 & 0,1 & 0,3 & 0,3 & 96,5 & 0,5 & 0,2 & 0,2 & 0,3 & 1,5 & 12,8 \\
\hline $\begin{array}{l}\text { Hogere adm, commerciele } \\
\text { beroepen e.d. }\end{array}$ & 0,0 & 0,0 & 0,1 & 0,3 & 1,0 & 0,4 & 95,9 & 0,1 & 0,5 & 0,6 & 1,1 & 16,7 \\
\hline $\begin{array}{l}\text { Wetenschappelijke } \\
\text { beroepen (techniek etc) }\end{array}$ & 0,0 & 0,0 & 0,1 & 0,2 & 0,1 & 0,4 & 0,4 & 96,6 & 0,5 & 0,5 & 1,1 & 4,6 \\
\hline $\begin{array}{l}\text { Wetenschappelijke } \\
\text { economische adm. } \\
\text { beroepen e.d. }\end{array}$ & 0,0 & 0,0 & 0,0 & 0,1 & 0,5 & 0,2 & 1,2 & 0,4 & 95,9 & 0,6 & 0,9 & 6,8 \\
\hline Werkloosheid & 4,2 & 4,3 & 6,7 & 3,1 & 6,1 & 2,0 & 2,1 & 0,7 & 1,1 & 36,2 & 33,5 & 4,0 \\
\hline Non-participatie & 0,8 & 0,6 & 1,1 & 0,4 & 0,6 & 0,3 & 0,2 & 0,1 & 0,1 & 2,6 & 93,4 & 64,4 \\
\hline
\end{tabular}


Tabel B5.6: Mobiliteit tussen beroepen tussen kwartalen $t$ en $t+1$ (1 digit) in 2003 (ongewogen)

\begin{tabular}{|c|c|c|c|c|c|c|c|c|c|c|c|c|}
\hline$n^{t+1}$ & $\begin{array}{c}\text { Elementaire } \\
\text { beroepen }\end{array}$ & $\begin{array}{c}\text { Lagere } \\
\text { Beroepen } \\
\text { (techniek } \\
\text { etc) }\end{array}$ & $\begin{array}{l}\text { Lagere adm., } \\
\text { commerciële } \\
\text { beroepen } \\
\text { e.d. }\end{array}$ & $\begin{array}{l}\text { Middelbare } \\
\text { beroepen } \\
\text { (techniek } \\
\text { etc) }\end{array}$ & $\begin{array}{l}\text { Middelbare } \\
\text { adm., } \\
\text { commerciële } \\
\text { beroepen } \\
\text { e.d. }\end{array}$ & $\begin{array}{c}\text { Hogere } \\
\text { beroepen } \\
\text { (techniek } \\
\text { etc) }\end{array}$ & $\begin{array}{l}\text { Hogere } \\
\text { adm., } \\
\text { commerciële } \\
\text { beroepen } \\
\text { e.d. }\end{array}$ & $\begin{array}{l}\text { Wetenschap- } \\
\text { pelijke } \\
\text { beroepen } \\
\text { (techniek } \\
\text { etc) }\end{array}$ & $\begin{array}{l}\text { Wetenschap- } \\
\text { pelijke } \\
\text { economische } \\
\text { adm. } \\
\text { beroepen } \\
\text { e.d. }\end{array}$ & $\begin{array}{l}\text { Werkloos- } \\
\text { heid }\end{array}$ & $\begin{array}{c}\text { Non- } \\
\text { participatie }\end{array}$ & $\begin{array}{c}\mathrm{N} \\
(\mathrm{x} 1000)\end{array}$ \\
\hline Elementaire beroepen & 88,4 & 0,6 & 0,9 & 0,5 & 0,6 & 0,1 & 0,1 & 0,0 & 0,0 & 1,9 & 6,9 & 8,6 \\
\hline $\begin{array}{l}\text { Lagere Beroepen (techniek } \\
\text { etc) }\end{array}$ & 0,4 & 95,3 & 0,2 & 0,6 & 0,2 & 0,1 & 0,1 & 0,0 & 0,0 & 1,0 & 2,1 & 16,8 \\
\hline $\begin{array}{l}\text { Lagere adm., commerciele } \\
\text { beroepen e.d. }\end{array}$ & 0,5 & 0,3 & 91,7 & 0,2 & 1,2 & 0,1 & 0,2 & 0,0 & 0,0 & 1,3 & 4,6 & 15,0 \\
\hline $\begin{array}{l}\text { Middelbare beroepen } \\
\text { (techniek etc) }\end{array}$ & 0,1 & 0,2 & 0,1 & 97,2 & 0,3 & 0,2 & 0,2 & 0,0 & 0,1 & 0,5 & 1,1 & 25,5 \\
\hline $\begin{array}{l}\text { Middelbare adm, } \\
\text { commerciele beroepen e.d. }\end{array}$ & 0,1 & 0,1 & 0,4 & 0,2 & 96,0 & 0,1 & 0,6 & 0,0 & 0,1 & 0,7 & 1,5 & 31,0 \\
\hline $\begin{array}{l}\text { Hogere beroepen (techniek } \\
\text { etc) }\end{array}$ & 0,0 & 0,0 & 0,1 & 0,2 & 0,2 & 97,0 & 0,3 & 0,2 & 0,1 & 0,4 & 1,4 & 13,6 \\
\hline $\begin{array}{l}\text { Hogere adm, commerciele } \\
\text { beroepen e.d. }\end{array}$ & 0,0 & 0,1 & 0,1 & 0,1 & 0,7 & 0,2 & 96,6 & 0,1 & 0,3 & 0,7 & 1,1 & 17,8 \\
\hline $\begin{array}{l}\text { Wetenschappelijke } \\
\text { beroepen (techniek etc) }\end{array}$ & 0,0 & 0,0 & 0,0 & 0,2 & 0,1 & 0,2 & 0,6 & 96,8 & 0,4 & 0,6 & 1,1 & 5,1 \\
\hline $\begin{array}{l}\text { Wetenschappelijke } \\
\text { economische adm. } \\
\text { beroepen e.d. }\end{array}$ & 0,0 & 0,0 & 0,1 & 0,1 & 0,3 & 0,1 & 0,8 & 0,2 & 97,1 & 0,5 & 0,8 & 7,1 \\
\hline Werkloosheid & 3,6 & 3,7 & 4,8 & 2,5 & 5,1 & 1,4 & 1,9 & 0,6 & 0,7 & 44,7 & 30,9 & 5,3 \\
\hline Non-participatie & 0,7 & 0,5 & 0,8 & 0,3 & 0,6 & 0,2 & 0,2 & 0,1 & 0,0 & 3,0 & 93,6 & 66,1 \\
\hline
\end{tabular}


Tabel B5.7: Mobiliteit tussen beroepen tussen kwartalen $t$ en $t+1$ (1 digit) in 2004 (ongewogen)

\begin{tabular}{|c|c|c|c|c|c|c|c|c|c|c|c|c|}
\hline$n^{t+1}$ & $\begin{array}{c}\text { Elementaire } \\
\text { beroepen }\end{array}$ & $\begin{array}{c}\text { Lagere } \\
\text { Beroepen } \\
\text { (techniek } \\
\text { etc) }\end{array}$ & $\begin{array}{l}\text { Lagere adm., } \\
\text { commerciële } \\
\text { beroepen } \\
\text { e.d. }\end{array}$ & $\begin{array}{l}\text { Middelbare } \\
\text { beroepen } \\
\text { (techniek } \\
\text { etc) }\end{array}$ & $\begin{array}{l}\text { Middelbare } \\
\text { adm., } \\
\text { commerciële } \\
\text { beroepen } \\
\text { e.d. }\end{array}$ & $\begin{array}{c}\text { Hogere } \\
\text { beroepen } \\
\text { (techniek } \\
\text { etc) }\end{array}$ & $\begin{array}{l}\text { Hogere } \\
\text { adm., } \\
\text { commerciële } \\
\text { beroepen } \\
\text { e.d. }\end{array}$ & $\begin{array}{l}\text { Wetenschap- } \\
\text { pelijke } \\
\text { beroepen } \\
\text { (techniek } \\
\text { etc) }\end{array}$ & $\begin{array}{l}\text { Wetenschap- } \\
\text { pelijke } \\
\text { economische } \\
\text { adm. } \\
\text { beroepen } \\
\text { e.d. }\end{array}$ & $\begin{array}{l}\text { Werkloos- } \\
\text { heid }\end{array}$ & $\begin{array}{c}\text { Non- } \\
\text { participatie }\end{array}$ & $\begin{array}{c}\mathrm{N} \\
(\mathrm{x} 1000)\end{array}$ \\
\hline Elementaire beroepen & 89,5 & 0,9 & 0,7 & 0,3 & 0,5 & 0,1 & 0,1 & 0,0 & 0,0 & 1,9 & 5,9 & 10,0 \\
\hline $\begin{array}{l}\text { Lagere Beroepen (techniek } \\
\text { etc) }\end{array}$ & 0,4 & 95,2 & 0,2 & 0,6 & 0,2 & 0,1 & 0,0 & 0,0 & 0,0 & 1,2 & 2,0 & 18,8 \\
\hline $\begin{array}{l}\text { Lagere adm., commerciele } \\
\text { beroepen e.d. }\end{array}$ & 0,4 & 0,2 & 92,4 & 0,1 & 1,0 & 0,1 & 0,2 & 0,0 & 0,0 & 1,4 & 4,1 & 18,0 \\
\hline $\begin{array}{l}\text { Middelbare beroepen } \\
\text { (techniek etc) }\end{array}$ & 0,1 & 0,2 & 0,1 & 97,2 & 0,3 & 0,2 & 0,1 & 0,0 & 0,0 & 0,6 & 1,1 & 28,6 \\
\hline $\begin{array}{l}\text { Middelbare adm, } \\
\text { commerciele beroepen e.d. }\end{array}$ & 0,1 & 0,1 & 0,4 & 0,2 & 96,4 & 0,1 & 0,5 & 0,0 & 0,1 & 0,8 & 1,3 & 36,1 \\
\hline $\begin{array}{l}\text { Hogere beroepen (techniek } \\
\text { etc) }\end{array}$ & 0,0 & 0,0 & 0,0 & 0,2 & 0,3 & 97,0 & 0,4 & 0,2 & 0,1 & 0,4 & 1,2 & 16,9 \\
\hline $\begin{array}{l}\text { Hogere adm, commerciele } \\
\text { beroepen e.d. }\end{array}$ & 0,0 & 0,1 & 0,1 & 0,1 & 0,7 & 0,3 & 96,7 & 0,1 & 0,4 & 0,7 & 0,9 & 22,6 \\
\hline $\begin{array}{l}\text { Wetenschappelijke } \\
\text { beroepen (techniek etc) }\end{array}$ & 0,0 & 0,0 & 0,0 & 0,1 & 0,1 & 0,3 & 0,3 & 97,2 & 0,4 & 0,5 & 1,1 & 5,9 \\
\hline $\begin{array}{l}\text { Wetenschappelijke } \\
\text { economische adm. } \\
\text { beroepen e.d. }\end{array}$ & 0,0 & 0,0 & 0,1 & 0,1 & 0,3 & 0,2 & 0,8 & 0,2 & 97,2 & 0,4 & 0,7 & 7,9 \\
\hline Werkloosheid & 3,0 & 3,5 & 4,3 & 2,3 & 4,3 & 1,1 & 1,8 & 0,6 & 0,6 & 50,6 & 27,7 & 8,0 \\
\hline Non-participatie & 0,7 & 0,4 & 0,8 & 0,3 & 0,5 & 0,2 & 0,2 & 0,1 & 0,1 & 3,3 & 93,5 & 77,4 \\
\hline
\end{tabular}


Tabel B5.8: Mobiliteit tussen beroepen tussen kwartalen $t$ en $t+1$ (1 digit) in 2005 (ongewogen)

\begin{tabular}{|c|c|c|c|c|c|c|c|c|c|c|c|c|}
\hline$n^{t+1}$ & $\begin{array}{l}\text { Elementaire } \\
\text { beroepen }\end{array}$ & $\begin{array}{c}\text { Lagere } \\
\text { Beroepen } \\
\text { (techniek } \\
\text { etc) }\end{array}$ & $\begin{array}{c}\text { Lagere adm., } \\
\text { commerciële } \\
\text { beroepen } \\
\text { e.d. }\end{array}$ & $\begin{array}{l}\text { Middelbare } \\
\text { beroepen } \\
\text { (techniek } \\
\text { etc) }\end{array}$ & $\begin{array}{l}\text { Middelbare } \\
\text { adm., } \\
\text { commerciële } \\
\text { beroepen } \\
\text { e.d. }\end{array}$ & $\begin{array}{c}\text { Hogere } \\
\text { beroepen } \\
\text { (techniek } \\
\text { etc) }\end{array}$ & $\begin{array}{c}\text { Hogere } \\
\text { adm., } \\
\text { commerciële } \\
\text { beroepen } \\
\text { e.d. }\end{array}$ & $\begin{array}{l}\text { Wetenschap- } \\
\text { pelijke } \\
\text { beroepen } \\
\text { (techniek } \\
\text { etc) }\end{array}$ & $\begin{array}{l}\text { Wetenschap- } \\
\text { pelijke } \\
\text { economische } \\
\text { adm. } \\
\text { beroepen } \\
\text { e.d. }\end{array}$ & $\begin{array}{l}\text { Werkloos- } \\
\text { heid }\end{array}$ & $\begin{array}{c}\text { Non- } \\
\text { participatie }\end{array}$ & $\begin{array}{c}\mathrm{N} \\
(\mathrm{x} 1000)\end{array}$ \\
\hline Elementaire beroepen & 89,5 & 1,0 & 0,9 & 0,5 & 0,4 & 0,1 & 0,1 & 0,0 & 0,0 & 2,1 & 5,5 & 10,3 \\
\hline $\begin{array}{l}\text { Lagere Beroepen (techniek } \\
\text { etc) }\end{array}$ & 0,3 & 95,6 & 0,2 & 0,5 & 0,3 & 0,1 & 0,1 & 0,0 & 0,0 & 0,9 & 2,0 & 19,2 \\
\hline $\begin{array}{l}\text { Lagere adm., commerciele } \\
\text { beroepen e.d. }\end{array}$ & 0,4 & 0,2 & 93,2 & 0,2 & 1,1 & 0,1 & 0,2 & 0,0 & 0,1 & 1,2 & 3,4 & 18,8 \\
\hline $\begin{array}{l}\text { Middelbare beroepen } \\
\text { (techniek etc) }\end{array}$ & 0,1 & 0,2 & 0,1 & 97,4 & 0,3 & 0,3 & 0,1 & 0,0 & 0,0 & 0,4 & 1,1 & 29,8 \\
\hline $\begin{array}{l}\text { Middelbare adm, } \\
\text { commerciele beroepen e.d. }\end{array}$ & 0,1 & 0,1 & 0,3 & 0,2 & 96,5 & 0,1 & 0,6 & 0,0 & 0,1 & 0,7 & 1,3 & 37,8 \\
\hline $\begin{array}{l}\text { Hogere beroepen (techniek } \\
\text { etc) }\end{array}$ & 0,0 & 0,0 & 0,1 & 0,2 & 0,2 & 97,6 & 0,4 & 0,2 & 0,1 & 0,3 & 1,0 & 16,9 \\
\hline $\begin{array}{l}\text { Hogere adm, commerciele } \\
\text { beroepen e.d. }\end{array}$ & 0,0 & 0,1 & 0,1 & 0,2 & 0,7 & 0,2 & 96,6 & 0,1 & 0,5 & 0,6 & 0,9 & 22,3 \\
\hline $\begin{array}{l}\text { Wetenschappelijke } \\
\text { beroepen (techniek etc) }\end{array}$ & 0,0 & 0,0 & 0,0 & 0,3 & 0,2 & 0,3 & 0,4 & 96,7 & 0,3 & 0,7 & 1,0 & 6,3 \\
\hline $\begin{array}{l}\text { Wetenschappelijke } \\
\text { economische adm. } \\
\text { beroepen e.d. }\end{array}$ & 0,0 & 0,0 & 0,1 & 0,0 & 0,3 & 0,2 & 1,2 & 0,2 & 96,7 & 0,4 & 0,9 & 8,2 \\
\hline Werkloosheid & 3,2 & 3,2 & 4,3 & 2,2 & 4,8 & 1,3 & 2,1 & 0,5 & 0,6 & 49,2 & 28,6 & 8,7 \\
\hline Non-participatie & 0,7 & 0,4 & 0,9 & 0,3 & 0,6 & 0,2 & 0,2 & 0,1 & 0,0 & 3,4 & 93,2 & 81,5 \\
\hline
\end{tabular}




\section{Bijlage 6: Weging beroepenmobiliteit}

In de adviesnota Weging beroepenmobiliteit (Boonstra en Kruiskamp, 2008) is het weegschema geformuleerd om de beroepenmobiliteit tussen kwartalen te schatten op basis van het EBB panel. Voor een verantwoording wordt verwezen naar deze CBS nota.

Het voorgestelde weegschema kan als volgt worden weergegeven:

Geslacht $2 \times$ Afkomst20 + LeeftijdGeslacht3 $\times$ GroteGemeente179 + Geslacht $2 \times$ Leeftijd38 + CWIinschrijvingsduur5 + CWIregio13 + Inkomen6 + Looncategorie3 + TypeHuishouden 3 + Arbeidspositie(t-1)4 + Arbeidspositie(t)4 + Opleiding(t-1)5 + CWItransitie4 + Verhuisd2.

waarbij deze variabelen de volgende betekenis hebben:

Geslacht2: (man, vrouw)

Afkomst20: ("Nederland $<15$ of $>64$ ", "Nederland, 15-64", "Suriname $<15$ of $>64$ ", "Suriname 15-64", "Turkije $<15$ of $>64$ ", "Turkije 15-64", "Marokko $<15$ of $>64$ ", "Marokko 1564", "Nederlandse Antillen $<15$ of $>64$ ", "Nederlandse Antillen 15-64", "Afrika, Azië, Zuid-Amerika $<15$ of $>64$ ", "Afrika, Azië, Zuid-Amerika 15-64", "Spanje, Portugal, Italië, Griekenland, Frankrijk, Malta, Cyprus", "België", "Duitsland", "Voormalig Joegoslavië en Voormalige Sovjet-Unie", "Voormalig Tsjecho-Slowakije, Polen, Bulgarije, Hongarije, Roemenië, Estland, Letland, Litouwen, Slovenië", "Zweden, Finland, Denemarken, Oostenrijk, Verenigd Koninkrijk, Ierland, Luxemburg", "Japan, Indonesië", "Overig westerse landen")

LeeftijdGeslacht3: ("0-14 jaar of 65-plus", "15-64 jaar, man", "15-64 jaar, vrouw")

GroteGemeente179: indeling naar gemeenten in 179 klassen

Leefdtijd38: ("0-14 jaar", "15 jaar", "16 jaar", "17 jaar", "18 jaar", "19 jaar", "20 jaar", "21 jaar", "22 jaar", "23 jaar", "24 jaar", "25 jaar", "26 jaar", "27 jaar", "28 jaar", "29 jaar", "30 jaar", "31-34 jaar", "35-39 jaar", "40-44 jaar", "45-49 jaar", "50 jaar", "51 jaar", "52 jaar", "53 jaar", "54 jaar", "55 jaar", "56 jaar", "57 jaar", "58 jaar", "59 jaar", "60 jaar", "61 jaar", "62 jaar", "63 jaar", "64 jaar", "65-74 jaar", "75-125 jaar")

CWIinschrijvingsduur5: ("niet ingeschreven", "ingeschreven en werkzaam", "minder dan 1 jaar ingeschreven en niet werkzaam", "1 tot 4 jaar ingeschreven en niet werkzaam", "4 jaar of meer ingeschreven en niet werkzaam")

CWIregio13: ("niet ingeschreven", "ingeschreven, Groningen", "ingeschreven, Friesland", "ingeschreven, Drenthe", "ingeschreven, Overijssel", "ingeschreven, Flevoland", "ingeschreven, Gelderland", "ingeschreven, Utrecht", "ingeschreven, Noord-Holland", "ingeschreven, Zuid-Holland", "ingeschreven, Zeeland", "ingeschreven, Noord-Brabant", "ingeschreven, Limburg")

Inkomen6: inkomen uit werk of uitkering in zes klassen: (minder dan 3000 euro of onbekend, 3000-10000 euro, 10000-15000 euro, 15000-20000 euro, 20000-30000 euro, meer dan 30000 euro)

Looncategorie3: (loon, uitkering, anders)

TypeHuishouden3: ("eenpersoonshuishouden", "huishouden met kind(eren)", "overige huishoudens")

Arbeidspositie(t-1)4: (werkzaam, werkloos, niet-beroepsbevolking categorieën $5 \mathrm{t} / \mathrm{m} 9$ van EBB-variabele arbeidspositie, rest)

Arbeidspositie(t)4: (werkzaam, werkloos, niet-beroepsbevolking categorieën $5 \mathrm{t} / \mathrm{m} 9$ van EBB-variabele arbeidspositie, rest) 
Opleiding(t-1)5: ((1 of 2 of 9), 3, 4, 5, (6 of 7)); de cijfers betreffen de $1^{\mathrm{e}}$ digit van de Standaard Onderwijsindeling (SOI) 2006

CWItransitie4: ("niet ingeschreven op t-1, ook niet op t", "niet ingeschreven op t-1, wel op t", "wel ingeschreven op t-1, niet op t", "wel ingeschreven op t-1, ook op t")

Verhuisd2: ("niet verhuisd"(0), "wel verhuisd"(1)) 